CITE AS: Lago, S., Sloggett, S., Schlueter, Z., Chow, W.Y., Williams, A., Lau, E., \& Phillips, C. (2017). Coreference and antecedent representation across languages. Journal of Experimental Psychology: Learning, Memory, and Cognition, 43(5), 795-817.

\title{
Coreference and antecedent representation across languages
}

\author{
Sol Lago ${ }^{\mathrm{a}}$, Shayne Sloggett ${ }^{\mathrm{b}}$, Zoe Schlueter $^{\mathrm{a}}$, Wing Yee Chow ${ }^{\mathrm{c}}$, Alexander Williams ${ }^{\mathrm{a}, \mathrm{d}}$, \\ Ellen $\mathrm{Lau}^{\mathrm{a}}$ and Colin Phillips ${ }^{\mathrm{a}}$ \\ a Department of Linguistics, University of Maryland \\ ${ }^{\mathrm{b}}$ Department of Linguistics University of Massachusetts Amherst \\ ${ }^{\mathrm{c}}$ Department of Linguistics, University College London \\ ${ }^{\mathrm{d}}$ Department of Philosophy, University of Maryland
}

\begin{abstract}
Previous studies have shown that speakers of languages such as German, Spanish, and French reactivate the syntactic gender of the antecedent of a pronoun to license gender agreement. As syntactic gender is assumed to be stored in the lexicon, this has motivated the claim that pronouns in these languages reactivate the lexical entry of their antecedent noun. In contrast, in languages without syntactic gender such as English, lexical retrieval might be unnecessary. We used eye-tracking while reading to examine whether antecedent retrieval involves rapid semantic and phonological reactivation. We compared German and English. In German, we found early sensitivity to the semantic but not to the phonological features of the pronoun's antecedent. In English, readers did not immediately show either semantic or phonological effects specific to coreference. We propose that early semantic facilitation arises due to syntactic gender reactivation, and that antecedent retrieval varies cross-linguistically depending on the type of information relevant to the grammar of each language.
\end{abstract}

Keywords: coreference; German; English; sentence comprehension; eye-tracking Supplemental materials: http://dx.doi.org/10.1037/xlm0000343.supp 


\section{Introduction}

Theories of language comprehension aim to describe how speakers create and navigate representations of meaning during sentence processing. With words such as "told" and "month", comprehension primarily involves retrieving information stored in the mental lexicon. But with pronouns, such as "his" and "you", comprehension does not end with lexical access. Pronouns also need to be associated with a representation of their referent in a mental model of the discourse. This process draws on the lexical properties of the pronoun, on the syntactic class of the antecedent and also on the structure of discourse. In this paper we ask what can be learned about the relations between lexical access and the retrieval of discourse referents by using reading measures targeted at the process of interpreting pronouns.

We investigate whether the interaction between lexical and discourse information is influenced by grammatical properties that vary cross-linguistically. We compare German and English, which differ in a useful way. In contrast with English, German nouns have grammatical gender (masculine, feminine or neuter), which is a syntactic property that differs from conceptual gender (male, female). For example, although boys are male, the diminutive word for "boy" in German, "Bübchen", is syntactically neuter and permits a neuter pronoun. Also, inanimate nouns lack conceptual gender but they are specified for syntactic gender (e.g. "das Haus", 'the house.NEUTR'; "die Jacke", 'the jacket.FEM').

We assume, together with previous research, that the representation of a pronoun's referent in the discourse does not include the syntactic gender of its antecedent noun. Instead, syntactic gender is associated with the pronoun's linguistic antecedent (Garnham, 2001; Cacciari, Carreiras \& Barbolini-Cionini, 1997; Frazier, Henstra \& Flores d' Arcais, 1996; Garnham, Oakhill, Erlich \& Carreiras, 1995). If this is the case, then in order to identify a gender-matching antecedent during coreference, German speakers might need to reaccess information outside their discourse model, such as the antecedent's syntactic gender in the lexicon. In contrast, English speakers might not. In English, which lacks syntactic gender, the features necessary to identify an antecedent, which include conceptual gender, can be fully stored in the discourse representation of the pronoun's referent, obviating the need for lexical retrieval (Cloitre \& Bever, 1988; Lucas, Tanenhaus \& Carlson, 1990).

Given this cross-linguistic contrast between German and English, we focus on two questions: does antecedent retrieval in comprehension differ between languages with and without syntactic gender, such as German and English? And does the existence of syntactic gender in German result in further differences in what other types of antecedent information, phonological or semantic, are initially reactivated by a pronoun? The answer to these questions will shed some light on the structure of memory for prior discourse, and its relationship to other memory structures, such as the lexicon. 


\section{Previous evidence of retrieval of semantic and phonological features during coreference}

In languages with syntactic gender, such as German, Italian, and Spanish, pronouns must agree in syntactic gender with their antecedent. Previous research shows that comprehenders are sensitive to this requirement in processing (Cacciari, Carreiras \& Barbolini-Cionini, 1997; Carreiras, Garnham \& Oakhill, 1993; Frazier, Henstra \& Flores d' Arcais, 1996; Garnham, Oakhill, Erlich \& Carreiras, 1995; Meyer \& Bock, 1999). For example, Garnham and colleagues examined whether pronoun resolution is sensitive to the grammatical gender of the antecedent (Garnham et al., 1995). They used sentences that contained two noun phrases before an object pronoun. Both noun phrases were inanimate to ensure that grammatical gender did not correlate with conceptual gender. In several selfpaced reading studies in French and Spanish, reading times for clauses containing pronouns were faster when the two noun phrases differed in grammatical gender, suggesting that speakers were able to use syntactic gender as a cue to disambiguate between the two possible referents. In the domain of language production, Meyer and Bock (1999) found that when participants produced pronouns referring back to antecedents consisting of a noun and a prepositional phrase modifier, they made more agreement errors if the noun inside the modifier phrase had a different gender than the antecedent noun. This suggests that speakers of languages with syntactic gender retrieve information about the syntactic gender of the antecedents in order to select pronouns.

If it is assumed that the syntactic gender of a noun is not represented in the discourse but only stored under its lexical entry, these previous findings indicate that comprehenders of languages with syntactic gender must retrieve a lexical representation of a pronoun's antecedent during coreference. However, it is less clear whether the retrieval of the antecedent's gender is associated with the reactivation of other lexical information such as semantic and phonological features. Here we will adopt a model of the lexicon that proposes a distinction between the lemma of a word, which comprises its semantic and syntactic features, and its lexeme, which includes its form, phonological and orthographic (for review, see Levelt, Roelofs \& Meyer, 1999). Although this model was originally proposed for production, it has also been fruitfully applied to comprehension partly because it makes specific commitments with regard to how semantic and phonological information are represented and accessed in real time (e.g. Ito, Corley, Pickering, Martin, \& Nieuwland, 2016; van Gompel \& Majid, 2004). For instance, the model proposes that semantic and phonological information can be accessed separately during lexical retrieval and that phonological access occurs after semantic access. Under the assumption that predicting a word in comprehension is functionally equivalent to generating it in production, Ito and colleagues showed that the effect of a predictable context (e.g. "The student is going to the library to borrow a...") on the recognition of words related to the expected completion ("book") was observed rapidly for semantically related words like "page" (within 350-450 
ms after target word onset) but only after a delay for phonologically related words like "hook" (within 600-1000 ms after target word onset). The authors argued that the delay in phonological over semantic priming supported an account in which comprehenders use their production system to make predictions during comprehension. Meanwhile, van Gompel and Majid (2004) motivated their study on pronoun resolution by proposing that antecedent reactivation in comprehension could be conceptualized as similar to lexical access in production, and they distinguished between accounts in terms of whether pronouns reactivated semantic, syntactic and form-related antecedent features (a "full lexical reaccess account") or only semantic and syntactic ones (a "lemma re-access account", van Gompel \& Majid, 2004:256).

As the model by Levelt and colleagues allows separate access to lemma and lexeme information, if the process of antecedent reactivation is similar to lexical access, then pronouns may reactivate either syntactic or semantic features of their antecedent (lemma) or also their form. With regard to the reactivation of semantic features, pronouns could reactivate the semantic features of their antecedent through two routes: the lexicon or the discourse model. On any account, pronoun interpretation requires reference to the discourse model, which should result in some semantic information about the antecedent being re-activated. However, semantic reaccess at the lexical level might be faster or more automatic, and it should give rise to spreading activation effects to semantically related words in the lexical network (Collins \& Loftus, 1975; Forster, 1976; Levelt, Roelofs, \& Meyer, 1999; Morton, 1979). In contrast, spreading activation effects may not occur at the discourse level.

Previous evidence for the rapid reactivation of semantic antecedent features comes from cross-modal lexical decision studies in English, where participants performed a lexical decision task after hearing a pronoun embedded in a sentence (Leiman, 1982; Nicol, 1988; Shillcock, 1982). These studies found faster responses for words that were semantically related to the antecedent of the pronoun relative to unrelated words. For instance, Shillcock (1982) presented sentences like (1) auditorily. Participants performed a lexical decision to a visual probe at various points in the sentence (the asterisks mark the points in which a visual probe appeared on the screen in different trials). At the offset of the pronoun " $h e$ ", a facilitation effect was obtained: lexical decisions were faster for a word that was semantically related to the pronoun's antecedent "teacher" (e.g. "school") than for an unrelated word matched in length and frequency (e.g. "street"). In contrast, when the pronoun was "it" decision times were similar, suggesting that the facilitation of "school" in the "he" condition was not due to residual activation from the word "teacher" at the beginning of the sentence, but rather by antecedent reactivation specifically due to coreference between the pronoun " $h e$ " and its antecedent.

(1) The teacher* did not board the train, for the* simple reason that it / he* was not going to the South Coast of England. 
Visual probes: SCHOOL / STREET

Although these results support rapid reactivation of semantic antecedent features in English, there are several concerns about the cross-modal paradigm. First, semantic facilitation in these studies is highly dependent on the choice of control words (e.g. "street") and changes in their lexical properties were later found to eliminate the effect (McKoon, Ratcliff and Ward, 1994; for a rejoinder, see Nicol, Fodor, \& Swinney, 1994). A second concern is that the effect might have been due to task-related strategies, instead of automatic reactivation processes. This is because detecting semantic relationships between words improves participants' performance in the lexical decision task, which might encourage them to strategically focus on semantic relationships to perform better (Neely, 1991). As a result, it is unclear whether facilitation effects in cross-modal studies should carry over to more implicit comprehension studies, where participants' main task is to read sentences for meaning.

Meanwhile, reactivation of phonological antecedent features was found in a production study in German (Schmitt, Meyer \& Levelt, 1999). Participants were asked to verbally describe two successive pictures of an object (e.g. a flower). When the two pictures showed the same object in different colors, a pronoun was typically used to refer to the repeated object. Schmitt and colleagues found that if participants were interrupted to perform a lexical decision task when they were about to utter the pronoun, they showed an inhibition effect for words phonologically related to the antecedent. That is, words that shared the same onset with the antecedent of the pronoun (e.g., "Bluse" 'blouse' phonologically related to "Blume" 'flower') showed longer reaction times than unrelated words. This suggested that the form of the antecedent was re-accessed during the planning of the pronoun such that it interfered with the decision to a phonologically related word (but see Jescheniak, Schriefers, \& Hantsch, 2001 and Meyer \& Bock, 1999, which failed to find an effect of the antecedent's phonology on the production of pronouns using different paradigms).

However, we are not aware of evidence in comprehension that the antecedent's form or lexeme is reactivated during coreference. In addition, to our knowledge there is no evidence that supports reactivation of the antecedent's form in languages without syntactic gender, such as English. Therefore, one of the goals of the current study was to address whether form reactivation occurs in English and German, with a focus on comprehension instead of production. In what follows, we outline two experiments that aimed to examine phonological and semantic antecedent effects using the same task and a controlled comparison across English and German. 


\section{Overview of the experiments}

We examined the type of information about a pronoun's antecedent that is retrieved from memory in comprehension. Our experiments focused on the retrieval of semantic and phonological features of the antecedent. We asked whether retrieval differed between languages that have syntactic gender, such as German (Experiment 1), and those that do not, such as English (Experiment 2). We tracked comprehenders' eye-movements during reading to provide a more naturalistic measure of comprehension. In contrast with the cross-modal paradigm, eye-tracking offers a better temporal resolution and it does not require participants to make conscious decisions about the lexical relationships under investigation.

We devised a new strategy to probe for semantic and phonological reactivation. We reasoned that if pronouns quickly reactivate lexical information about their antecedent, then this information should impact the processing of immediately following words. We varied the type of relationship between the antecedent and the word after the pronoun, which we will refer to as the target word. We manipulated whether the relationship between the antecedent and the target word was semantic or phonological. This strategy is similar to cross-modal studies in that it examines how antecedent reaccess impacts the processing of incoming lexical material. But it differs in that it requires no secondary task, and it keeps the target word constant across the different experimental conditions, as shown in (2-3).

(2) Semantic conditions

a. Pronoun, Related

The maintenance men told the singer about a problem. They had broken his piano and would have to repair that first.

b. Pronoun, Unrelated

The maintenance men told the deputy about a problem. They had broken his piano and would have to repair that first.

c. Determiner, Related

The maintenance men told the singer about a problem. They had broken the piano and would have to repair that first.

d. Determiner, Unrelated

The maintenance men told the deputy about a problem. They had broken the piano and would have to repair that first. 
(3) Phonological conditions

e. Pronoun, Related

The maintenance men told the singer there would be a delay. They said that his sink wouldn't be installed until next month.

f. Pronoun, Unrelated

The maintenance men told the deputy there would be a delay. They said that his sink wouldn't be installed until next month.

g. Determiner, Related

The maintenance men told the singer there would be a delay. They said that the sink wouldn't be installed until next month.

h. Determiner, Unrelated

The maintenance men told the deputy there would be a delay. They said that the sink wouldn't be installed until next month.

In the semantic conditions, we adopted a manipulation similar to the previous crossmodal studies on coreference (Leiman, 1982; Nicol, 1988; Shillcock, 1982). In the related conditions, the antecedent and target word were semantically/associatively related ("singer-piano"), whereas in the unrelated conditions they were not ("deputy-piano"). However, in contrast with previous studies, the target word, "piano", was always held constant across conditions, and relatedness was manipulated by varying the antecedent of the pronoun in the first sentence ("singer" vs. "deputy"). In the phonological conditions we based our manipulation of the phonological overlap between the antecedent and the target word on a previous production study in German (Schmitt, Meyer \& Levelt, 1999). In the related conditions, the antecedent and the target word shared the same onset ("singersink'), whereas in the unrelated conditions there was no phonological or orthographic overlap ("deputy-sink").

We hypothesized that if comprehenders immediately reactivate the lexical semantic and/or phonological features of an antecedent upon reading a coreferential pronoun, then these features should impact their processing of the subsequent word. In particular, in previous eye-tracking studies, lexical semantic association between prime-target pairs resulted in shorter reading times to the target word in early and late reading measures, as well as higher skipping rates (Camblin, Gordon, \& Swaab, 2007; Carroll \& Slowiaczek, 1986; Morris \& Folk, 1998). Therefore, if comprehenders immediately reactivate antecedent lexical semantic information upon processing a pronoun, then the target word "piano" should elicit shorter reading times when it is semantically related to the antecedent (e.g., "singer") than when it is not (e.g., "deputy"). 
Meanwhile, previous studies have shown that orthographic relationships can produce inhibition effects, resulting in longer reading times, higher skipping rates and more regressive eye-movements to a word that is preceded by an orthographically related word (e.g. "extra" when preceded by "extract" in "More time was allowed to extract/justify the extra information that was needed"; Patterson, Alcock, \& Liversedge, 2011; Patterson, Liversedge, \& Davis, 2009). Therefore, if comprehenders immediately reactivate phonological and/or orthographic features of an antecedent upon processing a pronoun, we should observe an inhibition effect in the phonological conditions: the target word "sink" should elicit longer reading times when it is phonologically and/or orthographically related to the antecedent (e.g., "singer") than when it is not (e.g., "deputy").

To probe whether antecedent reactivation specifically affected the recognition of the target word, our analyses focused on early eye-tracking measures at the target word. Specifically, we chose single-fixation, first fixation, first pass times and regression and skipping probabilities, since semantic and phonological effects are often found in these measures. We also report total reading times to provide a measure of second pass processing.

Finally, it is important to note that if relatedness effects are specifically due to referential processing (and not, for example, to residual activation from first encounter of the antecedent word), then they should be absent (or substantially reduced) in the absence of a coreferential pronoun. As determiners are less likely to immediately reactivate the antecedent noun, we included the determiner conditions to serve as the control comparisons in both the semantic and phonological materials. If semantic and phonological effects are specifically due to antecedent reactivation, then there should be no difference between related and unrelated target words in the determiner conditions.

\section{Experiment 1: German}

\subsection{Methods}

\subsubsection{Participants}

Participants $(n=60$, mean age $=25$ years, 46 females $)$ were all native speakers of German and were recruited from the University of Potsdam community. All participants provided informed consent and received either course credit or payment for their participation.

\subsubsection{Materials and design}

The experimental materials consisted of 64 sets of items distributed in 8 conditions. Each item consisted of a 2 -sentence passage. The second sentence contained a masculine or neuter possessive pronoun or determiner followed by the target word. Possessive pronouns simultaneously marked the gender of the antecedent and the target word. In German, the 
stem of a possessive pronoun conveys antecedent agreement (e.g. "Herr Müller...sein Sohn" vs. "Frau Müller...ihr Sohn") whereas the suffix of the possessive conveys agreement with the following noun (e.g. "Herr Müller... sein Sohn" vs. "... seine Tochter"). A sample item set is shown in Table 1 and the full item sets are available in the Supplemental Materials (Appendix A).

The first sentence introduced the antecedent of the pronoun, which was realized as the direct object of a transitive verb. Note that in German, grammatical gender is expressed not only on the noun but also on its modifiers (e.g. determiners and adjectives). All antecedents were singular and had male conceptual gender and masculine grammatical gender, with the exception of one antecedent, which was neuter. In contrast, the sentential subjects were always plural and had feminine grammatical gender. This ensured that the pronoun in the second sentence unambiguously referred to the direct object of the first sentence.

We varied whether the antecedent of the pronoun was related or unrelated to the target word. This relationship could be semantic (e.g. Zeichenlehrer-BILD, 'drawing teacher-PAINTING') or phonological/orthographic (e.g. Zeichenlehrer-ZEITUNG, 'drawing teacher-NEWSPAPER'). In the latter case, the antecedent and target word overlapped in at least the first two characters and phonemes of the target's onset $\left(\right.$ mean $_{\text {orth }}=$ $2.88, \mathrm{SD}_{\text {orth }}=0.95 ;$ mean $\left._{\text {phon }}=2.51, \mathrm{SD}_{\text {phon }}=1.01\right)$ according to the WebCelex database (Baayen, Piepenbrock, \& Van Rijn, 1993). For the unrelated conditions, the antecedent of the pronoun was replaced with a word that did not share a semantic or phonological relationship with the target word (e.g. Administrator-BILD, 'administrator-PAINTING' and Administrator-ZEITUNG, 'administrator-NEWSPAPER' respectively).

Semantic relatedness was normed in a separate study. Participants $(n=20$, mean age $=28$ years, 16 females) were shown the antecedent-target word pairs and asked to rate them on a scale from 1 (not related) to 7 (very related). Related pairs received a mean rating of $6(\mathrm{SD}=1.03)$ whereas unrelated pairs received a mean rating of $2.29(\mathrm{SD}=1.38)$. This difference was statistically significant $(\hat{\beta}=-3.81, S E=0.18, t=-20.79, p<.05)$. In addition, a separate group of participants $(n=40$, mean age $=26$ years, 27 females $)$ rated the plausibility of the sentences up to the target word on a scale from 1 (very implausible) to 7 (very plausible). The conditions in which the antecedent and target words were related were judged as more plausible than the unrelated conditions, but crucially, this difference was similar for the pronoun $\left(\right.$ mean $_{\text {rel }}=5.93, \mathrm{SD}_{\text {rel }}=1.37 ;$ mean $\left.n_{\text {unrel }}=4.72, \mathrm{SD}_{\text {unrel }}=1.76\right)$ and determiner conditions $\left(\right.$ mean $_{\text {rel }}=6.04, \mathrm{SD}_{\text {rel }}=1.24 ;$ mean $\left._{\text {unrel }}=4.65, \mathrm{SD}_{\text {unrel }}=1.78\right)$. This resulted in a main effect of semantic relatedness $(\hat{\beta}=1.39, S E=0.18, t=7.93, p<$ $.05)$ but no interaction between relatedness and determiner type $(\hat{\beta}=-0.18, S E=0.17, t=$ $-1.10, p=.28)$. There were no main effects or interactions in the phonological conditions. 
Related and unrelated antecedents were matched in lemma log frequency $\left(\right.$ mean $_{\text {rel }}$ $=0.88, \mathrm{SD}_{\text {rel }}=0.66 ;$ mean $\left._{\text {unrel }}=0.86, \mathrm{SD}_{\text {unrel }}=0.65\right)$ and length $\left(\right.$ mean $_{\text {rel }}=9.08, \mathrm{SD}_{\text {rel }}=$ 2.92; mean $_{\text {unrel }}=9.30, \mathrm{SD}_{\text {unrel }}=2.85$ ) using the German WebCelex database. To isolate relatedness effects specifically due to coreference from relatedness effects due to priming that stemmed from having read the antecedent noun in the previous sentence context, we also manipulated whether the target word was preceded by a pronoun or a determiner. This resulted in a $2($ related/unrelated $) \times 2($ semantic/phonological $) \times 2($ pronoun/determiner $)$ design.

The 64 item sets were divided into 8 lists, such that each list contained exactly one version of each item and 8 items in each condition. Thus, each participant never saw more than one version of the same item. The experiment also contained 72 two-sentence filler items of comparable length and complexity. Filler items contained other kinds of anaphors, such as feminine pronouns.

Table 1. Sample set of an experimental item and analysis regions in Experiment 1 (German). The regions of interest were the pre-target, target and post-target regions, which are delimited between slashes.

Semantic conditions

a. $\quad$ Pronoun, Related

Die Nachbarinnen mochten den Zeichenlehrer, der im obersten Stockwerk wohnte. Sie fanden, /dass sein/ Bild/, an dem/ er in seiner Freizeit gearbeitet hatte und das jetzt im Hausflur hing, sehr gut geworden war.

The neighbors liked the drawing teacher, who lived on the top floor. They thought that his painting, on which he had worked in his spare time and now hung in the hall, had become very good.

b. Pronoun, Unrelated

Die Nachbarinnen mochten den Administrator der im obersten Stockwerk wohnte. Sie fanden, /dass sein/ Bild/, an dem/ er in seiner Freizeit gearbeitet hatte und das jetzt im Hausflur hing, sehr gut geworden war.

... administrator... his painting...

c. Determiner, Related

Die Nachbarinnen mochten den Zeichenlehrer, der im obersten Stockwerk wohnte. Sie fanden, /dass das/ Bild/, an dem/ er in seiner Freizeit gearbeitet hatte und das jetzt im Hausflur hing, sehr gut geworden war.

... drawing teacher... the painting...

d. Determiner, Unrelated 
Die Nachbarinnen mochten den Administrator der im obersten Stockwerk wohnte. Sie fanden, /dass das/ Bild/, an dem/ er in seiner Freizeit gearbeitet hatte und das jetzt im Hausflur hing, sehr gut geworden war.

... administrator... the painting...

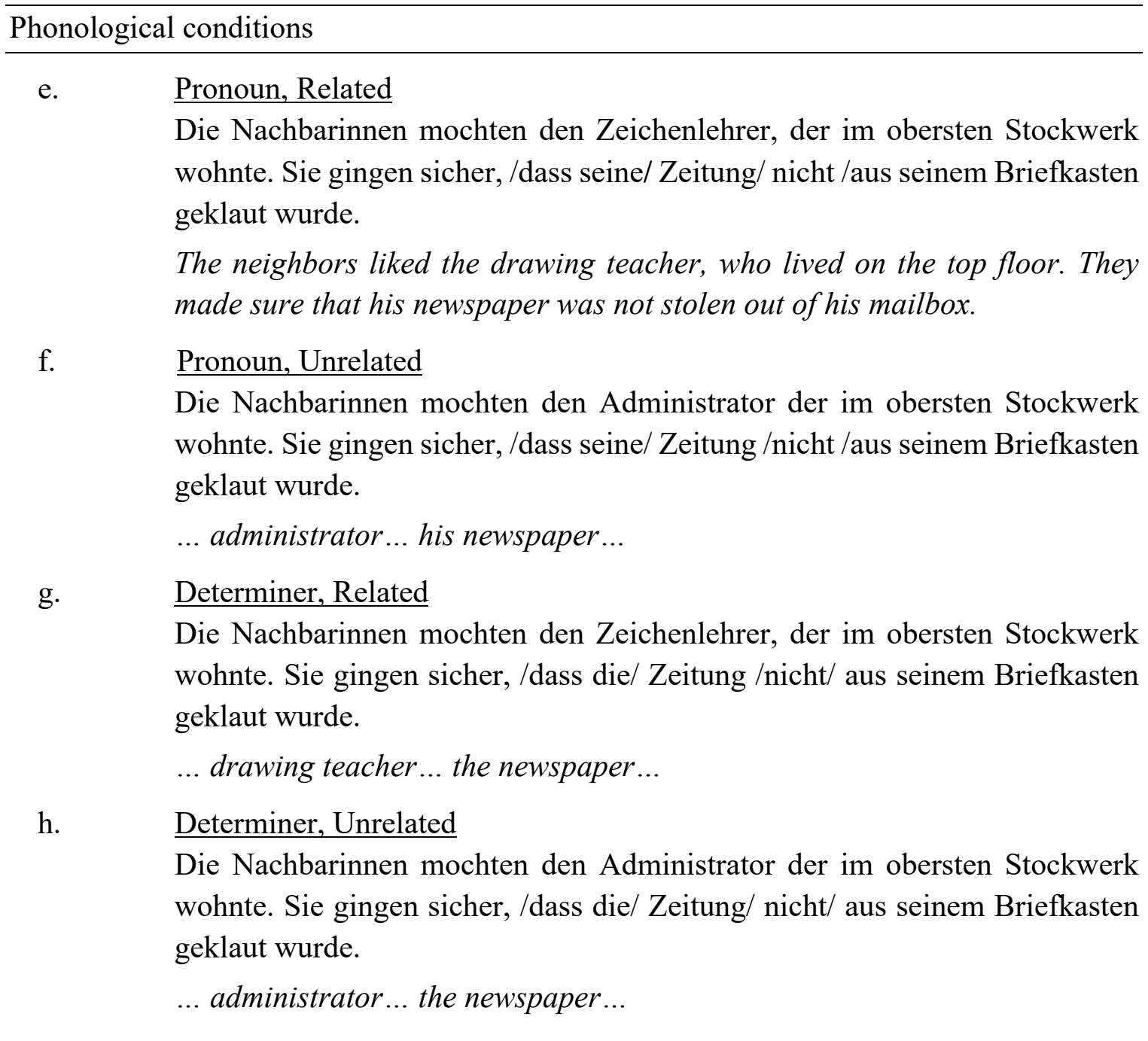

\subsubsection{Procedure}

Participants were tested individually and eye movements were recorded using a desktopmounted EyeLink 1000 eyetracker (SR Research, Mississauga, Ontario, Canada) interfaced with a Lenovo Thinkpad PC. The sampling rate was $1000 \mathrm{~Hz}$. Stimuli were displayed on a 22-inch EIZO LCD monitor. Sentences were presented in 14 pt. Times New Roman font. Participants were seated $62 \mathrm{~cm}$ from the computer screen. At this distance 
4.2 characters subtended approximately $1^{\circ}$ of visual arc. Viewing was binocular, but only the right eye was recorded. Each sentence was displayed on a single line.

The experiment was implemented using the Experiment Builder software (SR Research, Mississauga, Ontario, Canada). A calibration procedure was performed at the beginning of each testing session, and re-calibration was carried out between trials as needed. Before the experiment began, each participant was instructed to read for comprehension in a normal manner. The participant triggered the onset of each sentence by fixating on a reference point on the left edge of the computer screen where the first word of the sentence was to appear. Each participant read six practice items before the experimental items were shown. All experimental and filler items were followed by a yes/no comprehension question to ensure that participants were attending to the stimuli. Comprehension questions never alluded to the referential dependency between the pronoun and its antecedent. The order of experimental and filler items was pseudo-randomized such that each experimental item was preceded by at least one filler item. The entire experimental session lasted approximately 45 minutes.

\subsubsection{Analysis}

The initial stages of data analysis were carried out using Data Viewer (SR Research, Mississauga, Ontario, Canada). Examination of the data revealed that no long duration track losses (e.g., missing data for half a line of text or more) occurred at any time during a trial. Fixations were adjusted vertically only in cases in which an entire sequence of fixations comprising at least half of the line fell above or below a line of text (i.e. fixations were never adjusted either horizontally or individually). Lastly, fixations shorter than 40 ms or longer than $1000 \mathrm{~ms}$ were excluded $(0.65 \%)$.

The target region consisted of the word following the pronoun. We also analyzed the regions immediately before and after the target region: the post-target (spillover) and the pre-target region, which consisted of the determiner or pronoun together with the preceding complementizer "dass" ('that'). Including fixations to the left of a region of interest is a common procedure for analyzing short regions, because short words such as pronouns are often processed during a fixation close to the left of the word when they are skipped (Ehrlich \& Rayner, 1983; Garrod, Freudenthal, \& Boyle, 1994; van Gompel \& Majid, 2004). Table 1 shows the division into regions for a sample item.

Since we were interested in whether the recognition of the target word was influenced by antecedent reactivation, we focused our analyses on early eye-tracking measures at the target word. However, we also report total time (the sum of all fixations in a region) in order to capture processing differences that occurred after comprehenders' initial processing of the region of interest. For early measures, we report single fixation duration (the duration of readers' first fixation in a region when it is the only fixation in the region), first fixation duration (the duration of readers' first fixation in a region, 
provided that they did not previously fixate on subsequent text) and first pass reading times (the sum of all fixations on a critical region before readers leave it for the first time, either to the left or to the right). Also, given that pronouns elicit a large number of regressive eye movements (Ehrlich \& Rayner, 1983; van Gompel \& Majid, 2004) and that phonological and semantically related words have previously been found to be skipped more often, we report the probability of regression and probability of skipping. For all dependent variables, trials in which the region under consideration was skipped (i.e., cases in which the dependent fixation measure was 0 ) were excluded from the statistical analyses.

Statistical analyses were carried out with $\mathrm{R}$, an open source programming language and environment for statistical computing (R Development Core Team, 2016), using the lme4 package (Bates, Maechler, Bolker \& Walker, 2015). Reading times were logged and then analyzed with linear mixed effects models. Binomial measures and comprehension accuracy were analyzed using mixed effects logistic regression (Jaeger, 2008). P-values were computed with the lmerTest package using Satterthwaite's approximation for denominator degrees of freedom (Kuznetsova, Bruun Brockhoff, \& Haubo Bojesen Christensen, 2014).

We analyzed the semantic and phonological conditions separately, since they contained different target words. The statistical model included fixed effects of determiner type (pronoun vs. determiner), relatedness (related vs. unrelated) and their interaction. Both main effects were coded using orthogonal contrasts. For the determiner type factor, the mean of the pronoun conditions was compared with the mean of the determiner conditions. For the relatedness factor, the mean of the related conditions was compared with the mean of the unrelated conditions.

In addition to the experimental effects of interest, the analysis included several nuisance variables as covariates to ensure that the results were not due to variability in skipping rates across conditions or differences between word frequency and length across items. For the pre-target region the nuisance variables included character length and its interaction with the experimental effects of interest. For the target region the nuisance variables included (i) the length of the pre-target region, (ii) the length of the target region, (iii) the frequency of the target region, (iv) whether the pre-target region had been skipped or not. In addition, to ensure that our critical interaction between relatedness and determiner type in single fixation at the target word did not originate from an uneven distribution of fixations across items, the interaction between pre-target skipping rates and the experimental effects of interest was added to the model. All numeric predictors were centered before being entered in the analysis.

We present the model estimates in $\log$ milliseconds $(\hat{\beta})$, their standard error, and $t$ , $z$ - and $p$-values in the tables below. The random effects structure of the models included random intercepts and slopes for both experimental effects by participants and items. When 
the models failed to converge, we gradually simplified them following the guidelines in Barr, Levy, Scheepers, and Tily (2013). In the semantic conditions, non-convergence occurred for first fixation at the pre-target region and probability of regression at the pretarget and target regions. In the phonological conditions, non-convergence occurred for first-fixation at the target region and probability of regression at the pre-target and target regions. The simplified models removed the by-item slopes.

\subsection{Results}

Average accuracy in the comprehension questions was $93.4 \%$ in the semantic conditions and $93.5 \%$ in the phonological conditions. Table 2 shows means and standard errors for the measures of interest. Pairwise comparisons are reported in the text. 
Table 2. Region averages and standard errors in milliseconds in Experiment 1 (German).

\begin{tabular}{|c|c|c|c|c|c|c|}
\hline & \multicolumn{4}{|c|}{ Measures } & \multirow[b]{2}{*}{$\begin{array}{c}\text { Prob. of } \\
\text { regression } \\
{[\%]}\end{array}$} & \multirow[b]{2}{*}{$\begin{array}{c}\text { Prob. of } \\
\text { skipping } \\
{[\%]} \\
\end{array}$} \\
\hline & $\begin{array}{c}\text { Single } \\
\text { fixation } \\
{[\mathrm{ms}]} \\
\end{array}$ & $\begin{array}{c}\text { First } \\
\text { fixation } \\
{[\mathrm{ms}]} \\
\end{array}$ & $\begin{array}{l}\text { First } \\
\text { pass } \\
{[\mathrm{ms}]} \\
\end{array}$ & $\begin{array}{l}\text { Total } \\
\text { time } \\
{[\mathrm{ms}]} \\
\end{array}$ & & \\
\hline \multicolumn{7}{|l|}{ Semantic conditions } \\
\hline \multicolumn{7}{|l|}{ Pre-target } \\
\hline Pronoun, Related & $286(8)$ & $250(5)$ & $382(9)$ & $478(12)$ & $11(1)$ & $6(1)$ \\
\hline Pronoun, Unrelated & $275(7)$ & $241(4)$ & $363(8)$ & $476(12)$ & $14(2)$ & $7(1)$ \\
\hline Determiner, Related & $263(5)$ & $242(4)$ & $320(7)$ & $391(9)$ & $11(1)$ & $10(1)$ \\
\hline Determiner, Unrelated & $256(5)$ & $246(4)$ & $343(9)$ & $425(12)$ & $11(1)$ & $12(1)$ \\
\hline \multicolumn{7}{|l|}{ Target } \\
\hline Pronoun, Related & $222(6)$ & $226(5)$ & $311(12)$ & $353(13)$ & $8(1)$ & $34(2)$ \\
\hline Pronoun, Unrelated & $242(6)$ & $239(5)$ & $329(11)$ & $399(14)$ & $13(2)$ & $29(2)$ \\
\hline Determiner, Related & $228(5)$ & $234(5)$ & $288(10)$ & $340(11)$ & $12(1)$ & $30(2)$ \\
\hline Determiner, Unrelated & $223(5)$ & $234(5)$ & $288(10)$ & $365(15)$ & $14(2)$ & $29(2)$ \\
\hline \multicolumn{7}{|l|}{ Post-target } \\
\hline Pronoun, Related & $281(7)$ & $272(5)$ & $353(8)$ & $410(11)$ & $8(1)$ & $14(2)$ \\
\hline Pronoun, Unrelated & $294(7)$ & $274(5)$ & $357(8)$ & $433(11)$ & $10(1)$ & $16(2)$ \\
\hline Determiner, Related & $283(6)$ & $267(5)$ & $345(9)$ & $404(11)$ & $7(1)$ & $14(2)$ \\
\hline Determiner, Unrelated & $292(7)$ & $277(5)$ & $357(8)$ & $431(12)$ & $7(1)$ & $16(2)$ \\
\hline \multicolumn{7}{|l|}{ Phonological conditions } \\
\hline \multicolumn{7}{|l|}{ Pre-target } \\
\hline Pronoun, Related & $278(8)$ & $244(4)$ & $371(9)$ & $463(12)$ & $11(1)$ & $8(1)$ \\
\hline Pronoun, Unrelated & $271(7)$ & $247(4)$ & $382(9)$ & 469 (11) & $11(1)$ & $8(1)$ \\
\hline Determiner, Related & $264(6)$ & $247(4)$ & $330(8)$ & $425(12)$ & $12(1)$ & $13(2)$ \\
\hline Determiner, Unrelated & $265(6)$ & $247(4)$ & $346(9)$ & $419(10)$ & $10(1)$ & $9(1)$ \\
\hline \multicolumn{7}{|l|}{ Target } \\
\hline Pronoun, Related & $249(7)$ & $246(6)$ & $317(11)$ & $372(12)$ & $12(1)$ & $28(2)$ \\
\hline Pronoun, Unrelated & $236(7)$ & $242(5)$ & $319(10)$ & 365 (11) & $13(2)$ & $26(2)$ \\
\hline Determiner, Related & $237(7)$ & $241(5)$ & $319(10)$ & $395(13)$ & $14(2)$ & $25(2)$ \\
\hline Determiner, Unrelated & $239(6)$ & $242(5)$ & $322(11)$ & $378(15)$ & $13(2)$ & $28(2)$ \\
\hline \multicolumn{7}{|l|}{ Post-target } \\
\hline Pronoun, Related & $281(6)$ & $270(5)$ & $351(9)$ & $424(12)$ & $11(1)$ & $14(2)$ \\
\hline Pronoun, Unrelated & $264(4)$ & $259(4)$ & $342(9)$ & $396(11)$ & $10(1)$ & $14(2)$ \\
\hline Determiner, Related & $277(6)$ & $268(5)$ & $342(8)$ & $422(12)$ & $12(1)$ & $16(2)$ \\
\hline Determiner, Unrelated & $266(6)$ & $255(5)$ & $342(8)$ & $401(11)$ & $9(1)$ & $15(2)$ \\
\hline
\end{tabular}

\subsubsection{Semantic conditions}

\section{Pre-target region}


Table 3 shows the mixed effects model results for the pre-target region. ${ }^{1}$ The pre-target region was skipped on $8.7 \%$ of trials. The only effect at this region was a main effect of determiner type in skipping rates: pronouns were skipped less often than determiners. This effect is likely due to the fact that pronouns were less frequent than determiners, and encountering a pronoun should engage additional cognitive processes, such as the search for an antecedent.

Table 3. Linear mixed effects model estimates of logged reading times in Experiment 1 (German) in the semantic conditions at the pre-target region. For the determiner type factor, a positive estimate indicates that the pronoun conditions were read more slowly than the determiner conditions. For the relatedness factor, a positive estimate indicates that the related conditions were read more quickly than the unrelated conditions. Reliable effects at the $\alpha=.05$ level are in bold font.

\begin{tabular}{rccccccccc}
\hline Pre-target region & $\beta$ & $\mathrm{SE}$ & $t / z$ & $p$ & & $\beta$ & $\mathrm{SE}$ & $t / z$ & $p$ \\
\hline Single fixation & & & & & Total times & & & & \\
Length pre-target & 0.01 & 0.04 & 0.38 & .71 & & 0.07 & 0.04 & 1.58 & .12 \\
Determiner type & 0.05 & 0.06 & 0.75 & .45 & & 0.04 & 0.07 & 0.56 & .58 \\
Relatedness & 0.05 & 0.05 & 0.98 & .33 & & -0.05 & 0.05 & -0.95 & .35 \\
Length pre-target $\times$ Rel. & 0.04 & 0.05 & 0.77 & .44 & & 0.01 & 0.06 & 0.21 & .84 \\
Det. type $\times$ Rel. & -0.05 & 0.08 & -0.57 & .57 & & 0.05 & 0.09 & 0.52 & .60 \\
& & & & & & & & & \\
First fixation & & & & & Prob. of regression & & & & \\
Length pre-target & -0.02 & 0.03 & -0.64 & .53 & & 0.21 & 0.25 & 0.83 & .41 \\
Determiner type & 0.00 & 0.05 & -0.06 & .95 & & -0.01 & 0.44 & -0.03 & .98 \\
Relatedness & -0.02 & 0.04 & -0.65 & .52 & & -0.26 & 0.35 & -0.74 & .46 \\
Length pre-target $\times$ Rel. & -0.01 & 0.04 & -0.25 & .80 & & -0.38 & 0.36 & -1.05 & .30 \\
Det. type $\times$ Rel. & 0.06 & 0.06 & 0.92 & .36 & & 0.24 & 0.61 & 0.39 & .70 \\
& & & & & & & & & \\
First pass & & & & & Prob. of skipping & & & & \\
Length pre-target & -0.01 & 0.04 & -0.25 & .80 & & 0.65 & 0.37 & 1.76 & .08 \\
Determiner type & 0.07 & 0.07 & 1.06 & .29 & & -1.99 & $\mathbf{0 . 7 1}$ & $-\mathbf{2 . 7 9}$ & $<.05 *$ \\
Relatedness & -0.02 & 0.05 & -0.47 & .64 & & -0.99 & 0.57 & -1.75 & .08 \\
Length pre-target $\times$ Rel. & 0.05 & 0.05 & 0.94 & .35 & & -0.94 & 0.56 & -1.69 & .09 \\
Det. type $\times$ Rel. & 0.03 & 0.09 & 0.34 & .73 & & 1.44 & 0.98 & 1.47 & .14 \\
\hline
\end{tabular}

Target and post-target regions

Table 4 shows the mixed effects model results for the target region and Table 5 shows the results for the post-target region. The target and post-target regions were skipped on $30.4 \%$ and $14.8 \%$ of trials respectively. The target region showed a significant interaction between

${ }^{1}$ Note that the model outputs for the pre-target region do not include an interaction term between word length and determiner type. This is because the model with the interaction did not converge due to the high multicolinearity between these factors. 
relatedness and determiner type in both single fixation and total time. Pairwise comparisons revealed that the interaction was due to a significant relatedness effect in the pronoun conditions, where target words were read more quickly when they were semantically related to the antecedent (single fixation: $\hat{\beta}=0.09, S E=0.03, t=2.73, p<.05$; total time: $\hat{\beta}=0.13, S E=0.04, t=3.58, \mathrm{p}<.05)$. In contrast, no difference was observed in the determiner conditions (single fixation: $\hat{\beta}=-0.00, S E=0.03, t=-0.12, p=.91$; total time: $\hat{\beta}=0.01, S E=0.04, t=0.23, p=.82$ ).

The same pattern was observed in first fixation and first pass times. Although the interaction term was only marginally significant in these measures, we performed pairwise comparisons because they were motivated by our hypothesis and by the patterns seen in single fixation and total times. As expected, semantically related target words were read more quickly than unrelated words in the pronoun conditions in first fixation $(\hat{\beta}=0.05, S E$ $=0.03, t=1.83, p=.07)$ and first pass reading times $(\hat{\beta}=0.07, S E=0.03, t=2.10, p<$ $.05)$. In contrast, no difference was observed in the determiner conditions (first fixation: $\hat{\beta}$ $=-0.00, S E=0.00, t=-0.16, p=.88$; first pass: $\hat{\beta}=-0.01, S E=0.03, t=-0.36, p=.72$ ). However, note that these pairwise comparisons does not provide strong evidence for the absence of a relatedness effect in the determiner conditions in first fixation and first pass because the interaction term in the main model was only marginally significant.

In addition, the model results at the target region showed that some of the nuisance variables influenced reading times. Reading times were often longer when the target word was longer or more infrequent. Further, target words elicited more regressions when the pre-target word was skipped. None of these nuisance variables interacted with the experimental effects of interest.

Figure 1 displays semantic facilitation effects as difference scores, which show the difference in mean reading times between the related and unrelated conditions at the target region for each measure of interest (difference score $=$ mean $_{\text {unrelated }}-$ mean $_{\text {related }}$ ). Positive scores index priming, i.e. faster reading times in related than unrelated conditions. Negative scores index inhibition, i.e. slower reading times in related than unrelated conditions. In early measures, pronouns showed positive scores, consistent with priming. In contrast, there was no sign of facilitation in the determiner conditions, in which difference scores clustered around 0 . In total reading times, both pronouns and determiners showed priming. However, the effect was significantly larger in the pronoun conditions. 
Figure 1. Semantic facilitation effects in the target region in Experiment 1 (German). Mean difference scores and their standard error are shown with squares and bars respectively. Difference scores were computed as the mean difference between the unrelated and related conditions for determiners (det) and pronouns (pro) separately. Positive scores index priming and negative scores index inhibition. Difference scores are plotted in milliseconds for easier interpretability, but all statistical comparisons were performed on logged reading times. Note that the vertical scales differ because they correspond to different eye-tracking measures.

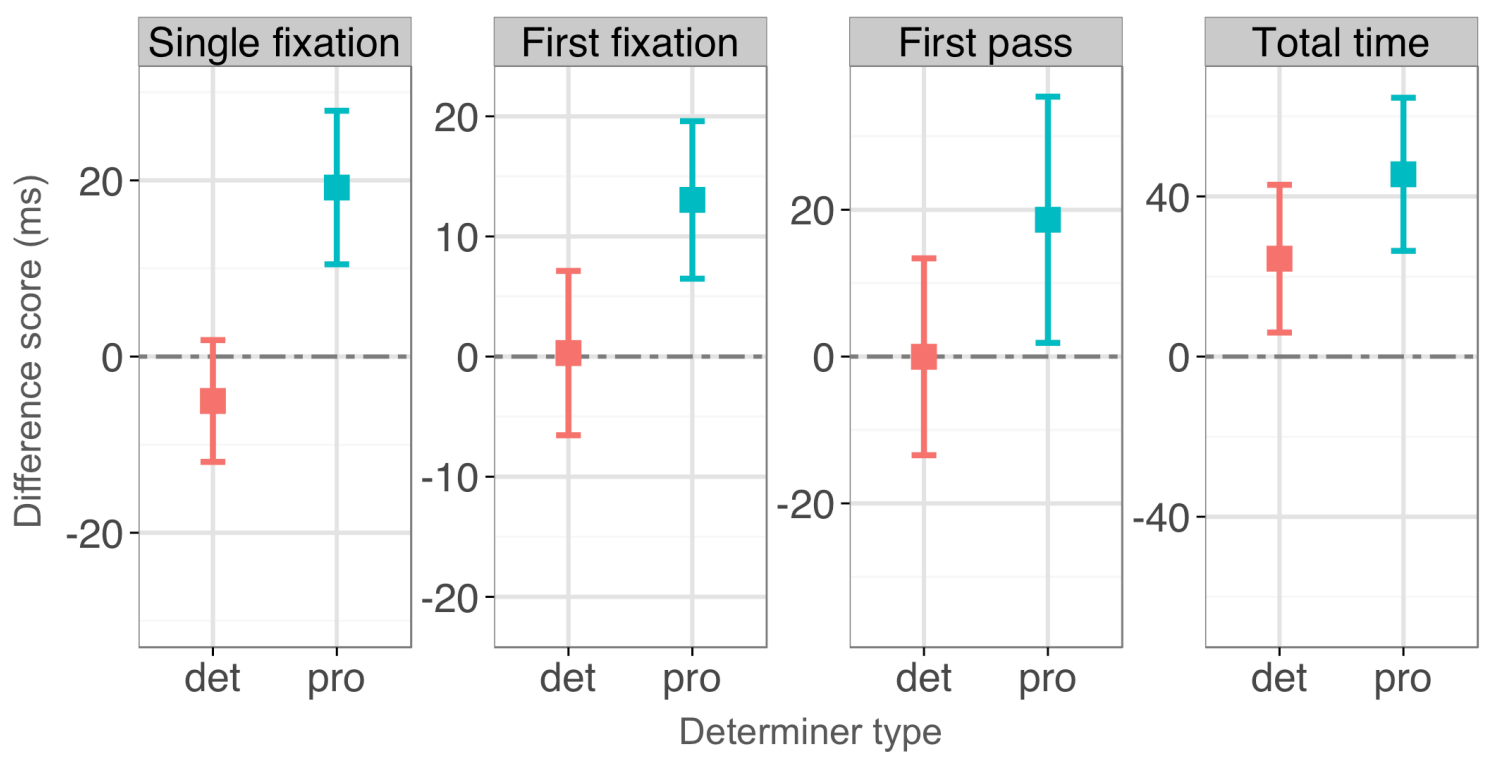

At the post-target region there was only a main effect of relatedness in total times, which was due to the post-target words being read more quickly in the semantically related conditions. 
Table 4. Linear mixed effects model estimates of logged reading times in Experiment 1 (German) in the semantic conditions at the target region. For the determiner type factor, a positive estimate indicates that the pronoun conditions were read more slowly than the determiner conditions. For the relatedness factor, a positive estimate indicates that the related conditions were read more quickly than the unrelated conditions. Reliable effects at the $\alpha=.05$ level are in bold font.

\begin{tabular}{|c|c|c|c|c|c|c|c|c|c|}
\hline Target region & $\beta$ & $\mathrm{SE}$ & $t / z$ & $p$ & & $\beta$ & $\mathrm{SE}$ & $t / z$ & $p$ \\
\hline Single fixation & & & & & Total times & & & & \\
\hline Length pre-target & -0.03 & 0.03 & -0.88 & .38 & & 0.01 & 0.04 & 0.20 & .85 \\
\hline Length target & 0.01 & 0.00 & 1.67 & .10 & & 0.05 & 0.01 & 6.77 & $<.05^{*}$ \\
\hline Frequency target & -0.07 & 0.02 & -4.68 & $<.05 *$ & & -0.09 & 0.03 & -2.99 & $<.05 *$ \\
\hline Skipping pre-target & 0.09 & 0.07 & 1.37 & .17 & & 0.28 & 0.07 & 3.98 & $<.05 *$ \\
\hline Determiner type & 0.10 & 0.06 & 1.79 & .08 & & 0.11 & 0.08 & 1.48 & .14 \\
\hline Relatedness & 0.01 & 0.03 & 0.18 & .86 & & 0.01 & 0.04 & 0.23 & .82 \\
\hline Skipping pre-target $\times$ Det. type & -0.05 & 0.12 & -0.40 & .69 & & -0.06 & 0.11 & -0.52 & .60 \\
\hline Skipping pre-target $\times$ Rel. & -0.02 & 0.09 & -0.22 & .82 & & -0.12 & 0.10 & -1.18 & .24 \\
\hline Det. type $\times$ Rel. & -0.09 & 0.04 & -2.15 & $<.05 *$ & & -0.13 & 0.05 & -2.52 & $<.05 *$ \\
\hline Skipping pre-target $\times$ Det. type $\times$ Rel. & 0.15 & 0.18 & 0.86 & .39 & & 0.12 & 0.17 & 0.70 & .48 \\
\hline First fi. & & & & & Prob. of regr & & & & \\
\hline Length pre-target & -0.01 & 0.03 & -0.45 & .66 & & 0.37 & 0.25 & 1.50 & .13 \\
\hline Length target & 0.01 & 0.00 & 1.84 & .07 & & 0.13 & 0.04 & 3.62 & $<.05 *$ \\
\hline Frequency target & -0.05 & 0.01 & -3.46 & $<.05 *$ & & -0.19 & 0.15 & -1.28 & .20 \\
\hline Skipping pre-target & -0.04 & 0.05 & -0.70 & .48 & & 1.78 & 0.37 & 4.83 & $<.05 *$ \\
\hline Determiner type & 0.03 & 0.05 & 0.73 & .47 & & -0.69 & 0.47 & -1.48 & .14 \\
\hline Relatedness & 0.00 & 0.03 & -0.07 & .95 & & -0.44 & 0.28 & -1.56 & .12 \\
\hline Skipping pre-target $\times$ Det. type & 0.09 & 0.09 & 1.00 & .32 & & 0.17 & 0.60 & 0.28 & .78 \\
\hline Skipping pre-target $\times$ Rel. & 0.01 & 0.07 & 0.12 & .91 & & 0.34 & 0.55 & 0.63 & .53 \\
\hline Det. type $\times$ Rel. & -0.07 & 0.04 & -1.73 & .08 & & -0.30 & 0.38 & -0.80 & .42 \\
\hline Skipping pre-target $\times$ Det. type $\times$ Rel. & 0.04 & 0.13 & 0.29 & .77 & & -0.72 & 0.95 & -0.75 & .45 \\
\hline First pass & & & & & Prob. of skipping & & & & \\
\hline Length pre-target & -0.02 & 0.04 & -0.45 & .65 & & -0.22 & 0.19 & -1.19 & .24 \\
\hline Length target & 0.04 & 0.01 & 7.13 & $<.05 *$ & & -0.34 & 0.04 & -9.20 & $<.05 *$ \\
\hline Frequency target & -0.08 & 0.02 & -3.18 & $<.05 *$ & & 0.33 & 0.13 & 2.50 & $<.05 *$ \\
\hline Skipping pre-target & -0.03 & 0.07 & -0.38 & .71 & & -0.64 & 0.41 & -1.54 & .12 \\
\hline Determiner type & 0.11 & 0.07 & 1.60 & .11 & & 0.34 & 0.33 & 1.04 & .30 \\
\hline Relatedness & 0.00 & 0.04 & -0.04 & .97 & & 0.16 & 0.18 & 0.89 & .37 \\
\hline Skipping pre-target $\times$ Det. type & 0.06 & 0.11 & 0.50 & .62 & & 0.23 & 0.66 & 0.35 & .73 \\
\hline Skipping pre-target $\times$ Rel. & -0.01 & 0.09 & -0.06 & .95 & & -0.47 & 0.61 & -0.77 & .44 \\
\hline Det. type $\times$ Rel. & -0.08 & 0.05 & -1.69 & .09 & & 0.06 & 0.24 & 0.26 & .79 \\
\hline Skipping pre-target $\times$ Det. type $\times$ Rel. & 0.07 & 0.16 & 0.44 & .66 & & 0.94 & 0.95 & 0.99 & .32 \\
\hline
\end{tabular}


Table 5. Linear mixed effects model estimates of logged reading times in Experiment 1 (German) in the semantic conditions at the post-target region. For the determiner type factor, a positive estimate indicates that the pronoun conditions were read more slowly than the determiner conditions. For the relatedness factor, a positive estimate indicates that the related conditions were read more quickly than the unrelated conditions. Reliable effects at the $\alpha=.05$ level are in bold font.

\begin{tabular}{|c|c|c|c|c|c|c|c|c|c|}
\hline Post-target region & $\beta$ & $\overline{S E}$ & $t / \mathrm{z}$ & $p$ & & $\beta$ & $\mathrm{SE}$ & $t / \mathrm{z}$ & $p$ \\
\hline Single fixation & & & & & Total times & & & & \\
\hline Determiner type & 0.00 & 0.02 & -0.20 & .84 & & 0.00 & 0.02 & 0.21 & .83 \\
\hline Relatedness & 0.03 & 0.02 & 1.44 & .16 & & 0.06 & 0.02 & 2.73 & $<.05^{*}$ \\
\hline Det $\times$ Rel & 0.01 & 0.04 & 0.21 & .83 & & -0.02 & 0.04 & -0.48 & .63 \\
\hline First fixation & & & & & Prob. of regression & & & & \\
\hline Determiner type & 0.00 & 0.02 & -0.01 & .99 & & 0.01 & 0.24 & 0.06 & .95 \\
\hline Relatedness & 0.02 & 0.02 & 1.22 & .23 & & 0.19 & 0.26 & 0.75 & .46 \\
\hline Det $\times$ Rel & -0.03 & 0.03 & -0.88 & .38 & & 0.59 & 0.43 & 1.38 & .17 \\
\hline First pass & & & & & Prob. of skipping & & & & \\
\hline Determiner type & 0.01 & 0.02 & 0.45 & .65 & & -0.21 & 0.19 & -1.12 & .26 \\
\hline Relatedness & 0.02 & 0.02 & 1.19 & .24 & & 0.23 & 0.20 & 1.12 & .26 \\
\hline Det $\times$ Rel & -0.03 & 0.04 & -0.86 & .39 & & 0.04 & 0.28 & 0.15 & .88 \\
\hline
\end{tabular}

\subsubsection{Phonological conditions}

Pre-target region

Table 6 shows the mixed effects model results for the pre-target region. The pre-target region was skipped on $9.4 \%$ of trials. No effects were observed in this region. 
Table 6. Linear mixed effects model estimates of logged reading times in Experiment 1 (German) in the phonological conditions at the pre-target region.

\begin{tabular}{rccccccccc}
\hline Pre-target region & $\beta$ & $\mathrm{SE}$ & $t / z$ & $p$ & & $\beta$ & $\mathrm{SE}$ & $t / z$ & $p$ \\
\hline Single fixation & & & & & Total times & & & & \\
Length pre-target & 0.03 & 0.05 & 0.57 & .57 & & 0.07 & 0.04 & 1.62 & .11 \\
Determiner type & -0.02 & 0.07 & -0.25 & .81 & 0.00 & 0.07 & -0.01 & 1.00 \\
Relatedness & 0.06 & 0.05 & 1.02 & .31 & & -0.02 & 0.05 & -0.38 & .71 \\
Length pre-target $\times$ Rel. & 0.07 & 0.06 & 1.11 & .27 & & -0.02 & 0.06 & -0.39 & .69 \\
Det. type $\times$ Rel. & -0.09 & 0.10 & -0.84 & .40 & & 0.04 & 0.09 & 0.38 & .71 \\
& & & & & & & & & \\
First fixation & & & & & Prob. of regression & & & & \\
Length pre-target & -0.02 & 0.03 & -0.66 & .51 & & 0.48 & 0.35 & 1.38 & .17 \\
Determiner type & 0.03 & 0.06 & 0.46 & .65 & & -0.55 & 0.59 & -0.93 & .36 \\
Relatedness & 0.04 & 0.04 & 1.08 & .28 & & 0.08 & 0.41 & 0.19 & .85 \\
Length pre-target $\times$ Rel. & 0.05 & 0.04 & 1.16 & .25 & & -0.24 & 0.43 & -0.55 & .58 \\
Det. type $\times$ Rel. & -0.08 & 0.07 & -1.14 & .26 & & 0.22 & 0.75 & 0.29 & .77 \\
& & & & & & & & & \\
First pass & & & & & Prob. of skipping & & & & \\
Length pre-target & 0.04 & 0.05 & 0.78 & .44 & & -0.22 & 0.41 & -0.55 & .59 \\
Determiner type & 0.04 & 0.08 & 0.47 & .64 & & 0.21 & 0.71 & 0.30 & .77 \\
Relatedness & -0.05 & 0.06 & -0.94 & .35 & & 0.19 & 0.52 & 0.36 & .72 \\
Length pre-target $\times$ Rel. & -0.01 & 0.06 & -0.19 & .85 & -0.33 & 0.53 & -0.63 & .53 \\
Det. type $\times$ Rel. & 0.04 & 0.10 & 0.40 & .69 & & -0.06 & 0.86 & -0.07 & .95 \\
\hline
\end{tabular}

Target and post-target regions

Table 7 shows the mixed effects model results for the target region and Table 8 shows the results for the post-target region. The target and post-target regions were skipped on $26.5 \%$ and $14.7 \%$ of trials respectively. There were no main effects or interactions for the experimental variables of interest at the target region, except where they interacted with nuisance variables. The analysis of the nuisance variables showed that reading times were often longer when the target word was longer or more infrequent. Further, target words sometimes elicited more regressions when the pre-target word was skipped. Finally, first pass reading times showed an interaction between pre-target skipping rates and relatedness and a three-way interaction between pre-target skipping rates, relatedness and determiner type. However, when trials were analyzed separately depending on whether the pre-target word had been skipped, there were no main effects or interactions between determiner type and relatedness.

In the post-target region, words after pronouns were skipped less often than words after determiners. In addition, the phonologically related conditions displayed longer reading times than the unrelated conditions in single fixation, first fixation and total time, consistent with an inhibition effect. Crucially, there was no interaction between relatedness and pronoun type, suggesting that inhibition affected pronouns and determiners alike. 
Table 7. Linear mixed effects model estimates of logged reading times in Experiment 1 (German) in the phonological conditions at the target region.

\begin{tabular}{|c|c|c|c|c|c|c|c|c|c|}
\hline Target region & $\beta$ & $\mathrm{SE}$ & $t / z$ & $p$ & & $\beta$ & $\mathrm{SE}$ & $t / z$ & $p$ \\
\hline Single fixation & & & & & Total times & & & & \\
\hline Length pre-target & -0.01 & 0.04 & -0.22 & .83 & & -0.01 & 0.05 & -0.26 & .79 \\
\hline Length target & 0.02 & 0.01 & 2.89 & $<.05 *$ & & 0.06 & 0.01 & 9.02 & $<.05^{*}$ \\
\hline Frequency target & -0.05 & 0.02 & -2.19 & $<.05^{*}$ & & -0.07 & 0.03 & -2.45 & $<.05 *$ \\
\hline Skipping pre-target & 0.16 & 0.08 & 1.91 & .06 & & 0.20 & 0.08 & 2.38 & $<.05 *$ \\
\hline Determiner type & -0.03 & 0.07 & -0.35 & .73 & & 0.02 & 0.09 & 0.19 & .85 \\
\hline Relatedness & -0.01 & 0.04 & -0.20 & .84 & & 0.05 & 0.04 & 1.40 & .16 \\
\hline Skipping pre-target $\times$ Det. type & -0.13 & 0.12 & -1.11 & .27 & & -0.09 & 0.12 & -0.81 & .42 \\
\hline Skipping pre-target $\times$ Rel. & -0.14 & 0.11 & -1.27 & .20 & & -0.03 & 0.10 & -0.30 & .76 \\
\hline Det. type $\times$ Rel. & 0.06 & 0.05 & 1.30 & .19 & & -0.02 & 0.05 & -0.39 & .70 \\
\hline Skipping pre-target $\times$ Det. type $\times$ Rel. & 0.12 & 0.18 & 0.69 & .49 & & 0.12 & 0.16 & 0.75 & .45 \\
\hline First fixation & & & & & Prob. of regression & & & & \\
\hline Length pre-target & 0.00 & 0.03 & -0.03 & .98 & & 0.02 & 0.23 & 0.10 & .92 \\
\hline Length target & 0.01 & 0.00 & 3.37 & $<.05 *$ & & 0.05 & 0.03 & 1.69 & .09 \\
\hline Frequency target & -0.03 & 0.02 & -1.68 & .10 & & -0.40 & 0.14 & -2.93 & $<.05 *$ \\
\hline Skipping pre-target & 0.02 & 0.07 & 0.27 & .79 & & 1.80 & 0.45 & 4.03 & $<.05 *$ \\
\hline Determiner type & -0.02 & 0.05 & -0.30 & .77 & & -0.08 & 0.46 & -0.19 & .85 \\
\hline Relatedness & -0.01 & 0.03 & -0.22 & .83 & & 0.20 & 0.30 & 0.68 & .50 \\
\hline Skipping pre-target $\times$ Det. type & -0.16 & 0.09 & -1.78 & .08 & & 1.13 & 0.62 & 1.81 & .07 \\
\hline Skipping pre-target $\times$ Rel. & -0.07 & 0.08 & -0.82 & .41 & & -0.36 & 0.57 & -0.64 & .53 \\
\hline Det. type $\times$ Rel. & 0.03 & 0.04 & 0.69 & .49 & & -0.08 & 0.36 & -0.23 & .82 \\
\hline Skipping pre-target $\times$ Det. type $\times$ Rel. & 0.17 & 0.13 & 1.36 & .17 & & -0.51 & 0.84 & -0.61 & .54 \\
\hline First pass & & & & & Prob. of skipping & & & & \\
\hline Length pre-target & -0.05 & 0.04 & -1.29 & .20 & & -0.49 & 0.22 & -2.25 & .02 \\
\hline Length target & 0.05 & 0.01 & 8.26 & $<.05 *$ & & -0.37 & 0.04 & -8.97 & $<.05 *$ \\
\hline Frequency target & -0.07 & 0.03 & -2.49 & $<.05 *$ & & 0.33 & 0.14 & 2.40 & $<.05 *$ \\
\hline Skipping pre-target & 0.01 & 0.09 & 0.17 & .86 & & -0.35 & 0.45 & -0.79 & .43 \\
\hline Determiner type & 0.10 & 0.08 & 1.23 & .22 & & 0.58 & 0.39 & 1.51 & .13 \\
\hline Relatedness & 0.02 & 0.04 & 0.63 & .53 & & -0.18 & 0.19 & -0.92 & .36 \\
\hline Skipping pre-target $\times$ Det. type & -0.28 & 0.12 & -2.35 & $<.05 *$ & & -0.30 & 0.68 & -0.43 & .67 \\
\hline Skipping pre-target $\times$ Rel. & -0.13 & 0.11 & -1.26 & .21 & & -0.23 & 0.61 & -0.37 & .71 \\
\hline Det. type $\times$ Rel. & -0.03 & 0.05 & -0.62 & .54 & & 0.29 & 0.26 & 1.12 & .26 \\
\hline Skipping pre-target $\times$ Det. type $\times$ Rel. & 0.34 & 0.16 & 2.07 & $<.05 *$ & & 0.23 & 0.94 & 0.24 & .81 \\
\hline
\end{tabular}


Table 8. Linear mixed effects model estimates of logged reading times in Experiment 1 (German) in the phonological conditions at the post-target region.

\begin{tabular}{|c|c|c|c|c|c|c|c|c|c|}
\hline Post-target region & $\beta$ & SE & $t / \mathrm{z}$ & $p$ & & $\beta$ & SE & $t / \mathrm{z}$ & $p$ \\
\hline Single fixation & & & & & Total times & & & & \\
\hline Determiner type & 0.01 & 0.02 & 0.42 & .67 & & 0.01 & 0.02 & 0.26 & .80 \\
\hline Relatedness & -0.06 & 0.02 & -2.74 & $<.05^{*}$ & & -0.06 & 0.02 & -2.85 & $<.05^{*}$ \\
\hline Det $\times$ Rel & -0.02 & 0.04 & -0.39 & .70 & & -0.03 & 0.04 & -0.61 & .54 \\
\hline First fixation & & & & & Prob. of regression & & & & \\
\hline Determiner type & 0.02 & 0.02 & 0.93 & .36 & & -0.06 & 0.19 & -0.31 & .76 \\
\hline Relatedness & -0.05 & 0.02 & -2.65 & $<.05 *$ & & -0.02 & 0.21 & -0.08 & .94 \\
\hline Det $\times$ Rel & 0.01 & 0.03 & 0.19 & .85 & & 0.48 & 0.34 & 1.38 & .17 \\
\hline First pass & & & & & Prob. of skipping & & & & \\
\hline Determiner type & 0.01 & 0.02 & 0.41 & .69 & & -0.50 & 0.23 & -2.21 & $<.05^{*}$ \\
\hline Relatedness & -0.02 & 0.02 & -1.16 & .25 & & -0.09 & 0.21 & -0.45 & .65 \\
\hline Det $\times$ Rel & -0.02 & 0.04 & -0.52 & .60 & & 0.00 & 0.29 & -0.01 & .99 \\
\hline
\end{tabular}

\subsection{Discussion}

We examined whether German comprehenders reactivate semantic and phonological antecedent information upon reading a pronoun. We found that the target word after the pronoun was read more quickly when it was semantically related to the pronoun's antecedent. In contrast, comprehenders showed no sensitivity to the antecedent phonological features. An inhibition effect consistent with phonological relatedness was only found in the post-target region and it occurred for both pronoun and determiners. This suggests that inhibition was due to residual activation from the phonologically related antecedent, and not to the reactivation of its form specifically due to the processing of the pronoun.

Crucially, semantic facilitation only occurred when the pre-target word was a pronoun, as supported by a significant interaction between relatedness and determiner type in single fixation and total reading times. Pairwise comparisons showed that semantically related targets were read more quickly than unrelated targets in the pronoun conditions, but not in the determiner conditions. This pattern suggests that semantic facilitation was specifically due to the processing of coreference. Together with the lack of evidence of a phonological effect specific to the pronoun conditions, these results suggest that German pronouns reactivate semantic but not phonological antecedent information during reading comprehension.

Note that although the determiner conditions were intended as a non-referential control, it is possible that at the definite determiner "the", participants expected a continuation that repeated the definite noun phrase referent ("...the drawing teacher... They made sure that the [drawing teacher] ..."). To address this possibility, we conducted a supplementary analysis that separated cases in which the target word matched the antecedent in gender (thus being consistent with a repeated antecedent completion) from 
cases in which it mismatched (thus being inconsistent with a repeated antecedent completion). However, there were no significant differences between these groups, suggesting that the unexpected effect of relatedness in the determiner conditions was not due to participants expecting a repeated noun phrase.

Before we provide an interpretation for the semantic facilitation effect, we should point out that whereas no facilitation was found for determiners in early measures, the numerical pattern in total reading times was consistent with facilitation: related words after determiners were read on average $25 \mathrm{~ms}$ faster than unrelated words. This effect may be due to several reasons. The first factor is that determiners can also introduce anaphoric relationships, as definite noun phrases may carry the presupposition that their referent was previously introduced in the discourse ("I bought a car. The car was big"; e.g. Heim, 1988). One interesting implication of our findings is that even if determiners are anaphoric, they do not seem to immediately trigger the reactivation of the antecedent's lemma to the same extent as pronouns.

Another possibility is that numeric pattern in total reading times reflects facilitation in later comprehension processes, such as accommodating the meaning of the target word into an ongoing discourse representation. Specifically, readers may have found it easier to incorporate the object "painting" to their discourse model when the first sentence introduced a drawing teacher, as opposed to an administrator, since drawing teachers are more strongly associated to paintings than administrators in the real world. Although the determiner should not have reactivated "teacher" initially, the remainder of the sentence supported the interpretation that the painting belonged to the drawing teacher/ administrator. In fact, several items contained a pronoun later in the sentence that referred to the antecedent and made it clear that the object belonged to him (e.g. "...They thought that the painting, on which he had worked in his spare time..."). This explanation would also be consistent with the results of the plausibility norming study, which directly asked participants to rate the likelihood of the sentence contexts and the target word. The results of the study showed that the related conditions were rated as more plausible than the unrelated conditions for pronouns and determiners alike.

Turning to the semantic facilitation in the pronoun conditions, our results support the hypothesis that when German comprehenders encounter a pronoun, they immediately reactivate the semantic features of its antecedent, which results in the eased recognition of semantically related target words. One possibility is that the semantic reactivation of the antecedent noun is lexical in nature. As outlined in the Introduction, speakers of languages with syntactic gender might need to retrieve a lexical representation of the antecedent noun during coreference, in order to license antecedent-pronoun gender agreement. If syntactic and semantic features are reaccessed together as part of a word's lemma (e.g. Kempen \& Huijbers, 1983; Levelt, 1989) then reaccess of the syntactic gender of the antecedent noun should also reactivate its semantic properties. 
Under this account, upon reading the pronoun, German speakers reactivated the lemma of the antecedent noun "drawing teacher", which includes its syntactic gender (masculine) and semantic properties. Most models of the lexicon posit that words are stored together in semantic networks, such that activation of a word can spread activation to highly associated words (i.e. a spreading activation mechanism, e.g. Collins \& Loftus, 1975; Forster, 1976; Levelt, Roelofs, \& Meyer, 1999; Morton, 1979). As a result, target words related to the antecedent noun, such as "painting", may have been preactivated when the antecedent noun was reactivated and they may have been read more quickly later as a result.

A different possibility is that semantic facilitation was due to the reactivation of the pronoun's referent in the discourse model. Although most theories assume that the discourse model encodes links to some kind of conceptual information, it is unclear whether discourse representations can induce spreading activation to semantic associates, as has been proposed for lexical relationships. Although no such semantic-spreading mechanism has been explicitly put forth for discourse models, some authors have suggested that comprehenders can sometimes add concepts that are associated with the pronoun's referent to their discourse model (Garrod \& Terras, 2000).

For example, it is possible that when the antecedent "drawing teacher" was encountered in our materials, comprehenders added the concepts of 'student' and 'painting' to their discourse, together with other concepts likely to be present in an event where a drawing teacher is present. When the pronoun was encountered, readers may have reactivated its discourse referent (the drawing teacher introduced in the first sentence) together with related concepts, resulting in the eased recognition of the target word when it matched any of the concepts stored with the pronoun's referent.

Our findings do not unambiguously determine whether the semantic facilitation we observed was due to retrieval of the pronoun's linguistic antecedent or to retrieval of its discourse referent. But since the retrieval of the lexical antecedent was motivated by the presence of syntactic gender in German, we contrasted these possibilities by testing English, a language without syntactic gender. We reasoned that if rapid semantic facilitation was caused by lexical reactivation due to the existence of syntactic gender, then this effect should be absent in English. In contrast, under a discourse reactivation account, English and German speakers should display similar facilitation effects, as reactivation of the pronoun's referent should occur in both languages.

\section{Experiment 2: English}

Experiment 2 examined whether English comprehenders show semantic facilitation effects during coreference. A crucial difference between English and German is that English nouns do not have syntactic gender. Instead, gender is either stereotypical ("janitor", "nurse") or 
entailed (e.g. "boy", "king"). In addition, most grammatical noun features such as animacy and number have conceptual correlates: for example, the plural number of a noun usually correlates with the numerosity of its referent in the discourse. Since these features can all arguably be represented in a discourse model, English speakers might not need to retrieve the lexical entry of a pronoun's antecedent because there is no additional benefit or requirement that comes from the antecedent's grammatical information.

We used this cross-linguistic difference to examine the source of the semantic facilitation effect in Experiment 1. We hypothesized that if semantic facilitation was due to reaccess of the syntactic features of the antecedent, then it should not occur in English, where the antecedent's syntactic gender is not grammatically encoded. Alternatively, under an account in which spreading activation can occur among related concepts in the discourse (without the need of lexical reactivation) then English comprehenders should show semantic facilitation effects. An early semantic facilitation effect in English would suggest either that semantic spreading does not require access to the lexicon, or alternatively, that English comprehenders access the lexicon during coreference, despite not needing to.

\subsection{Methods}

\subsubsection{Participants}

Participants $(n=60$, mean age $=21$ years, 38 females $)$ were all native speakers of English and were recruited from the University of Maryland community. All participants provided informed consent and received either course credit or payment for their participation.

\subsubsection{Materials and design}

We constructed 64 two-sentence item sets in a 2 (related/unrelated) $\times 2$ (semantic/phonological) $\times 2$ (pronoun/determiner) design. As in Experiment 1, the possessive pronoun was always in the second sentence and it was singular and had masculine gender. The first sentence introduced the antecedent of the pronoun as the direct object of a transitive verb. In contrast, the subject in the first sentence was plural and always mismatched the pronoun in number to ensure that all pronouns were unambiguous. We chose antecedent nouns that were likely to be gender-stereotypically male in order to further facilitate referent identification at the pronoun. The pronoun's antecedent varied in whether it shared a phonological or semantic relationship with the target word. Phonologically related antecedents overlapped with the target word in at least the first two characters and phonemes of the word's onset $\left(\right.$ mean $_{\text {orth }}=2.64, \mathrm{SD}_{\text {orth }}=1.03 ;$ mean $_{\text {phon }}=$ 3.33, $\left.\mathrm{SD}_{\text {phon }}=0.62\right)$. Phonetic transcriptions were obtained from the American pronunciation entries of the Oxford Dictionary and reviewed by a native speaker of American English from the Maryland area. 
Semantic relatedness was normed in a separate study. Participants $(n=20$, mean age $=28$ years, 10 females) were shown the antecedent-target word pairs and asked to rate them on a scale from 1 (not related) to 7 (very related). Related pairs received a mean rating of $5.62(\mathrm{SD}=1.33)$ whereas unrelated pairs received a mean rating of $2.82(\mathrm{SD}=1.33)$. This difference was statistically significant $(\hat{\beta}=-3.45, S E=0.20, t=-17.25, p<.05)$. A separate group of participants $(\mathrm{n}=40$, mean age $=28$ years, 19 females $)$ rated the plausibility of the sentences up to the target word on a scale from 1 (very implausible) to 7 (very plausible). The conditions in which the antecedent and target words were semantically related were deemed more plausible than the unrelated conditions, but crucially, this difference was similar for the pronoun $\left(\right.$ mean $_{\text {rel }}=6.17, \mathrm{SD}_{\text {rel }}=1.25 ;$ mean $_{\text {unrel }}$ $\left.=5.23, \mathrm{SD}_{\text {unrel }}=1.69\right)$ and determiner conditions $\left(\right.$ mean $_{\text {rel }}=5.97, \mathrm{SD}_{\text {rel }}=1.33 ;$ mean $_{\text {unrel }}=$ $\left.4.16, \mathrm{SD}_{\text {unrel }}=1.80\right)$. This resulted in a main effect of semantic relatedness $(\hat{\beta}=0.81, S E=$ $0.19, t=0.71, p<.05)$ but no interaction between relatedness and determiner type $(\hat{\beta}=$ $0.13, S E=0.19, t=0.74, p=.49)$. There were no main effects or interactions in the phonological conditions.

Related and unrelated antecedents were controlled in log frequency $\left(\right.$ mean $_{\text {rel }}=2.75$, $\mathrm{SD}_{\text {rel }}=0.55 ;$ mean $\left._{\text {unrel }}=2.72, \mathrm{SD}_{\text {unrel }}=0.61\right)$ and length $\left(\right.$ mean $_{\text {rel }}=7.41, \mathrm{SD}_{\text {rel }}=1.56$; mean $\left._{\text {unrel }}=7.13, \mathrm{SD}_{\text {unrel }}=1.60\right)$ using the SUBTLex database (Brysbaert \& New, 2009; available from the English Lexicon Project, Balota, Yap, Cortese, Hutchison, Kessler, Loftis, Neely, Nelson, Simpson, \& Treiman, 2007). The gender bias of the antecedent nouns was assessed separately using a gender norming task based on a previous study (Chow, Lewis, \& Phillips, 2014). Participants $(n=20$, mean age $=28$ years, 7 females) were shown the antecedent nouns and asked to rate them on a scale from 1 (most likely male) to 7 (most likely female). The mean rating of the antecedents was $2.89(\mathrm{SD}=1.42)$, indicating that they had a clear male-bias. The mean rating of the antecedent nouns in the related conditions was $2.73(\mathrm{SD}=1.44)$ and the mean rating of the antecedent nouns in the unrelated conditions was $3.03(\mathrm{SD}=1.40)$. Related and unrelated antecedents did not significantly differ in their gender bias $(\hat{\beta}=0.35, S E=0.19, t=1.84, p=.07)$.

Following Experiment 1, the pre-target region was lengthened by including the complementizer "that" before the pronoun. In items without a complementizer, we lengthened the pre-target region by including the last two characters of the preceding verb ( 26 out of 64 items). The regions of interest for one condition are shown in (4) between slashes, and a sample item set is shown in (2-3) above. The full item sets are available in the Supplemental Materials.

(4) The maintenance men told the singer about a problem. They had brok/en his/ piano/ and would/ have to repair that first.

The 64 item sets were divided into 8 lists, such that each list contained exactly one version of each item and 8 items in each condition. Thus, each participant saw each item 
and each condition, but never saw more than one version of the same item. The experiment also contained 72 two-sentence filler items of comparable length and complexity, which were adapted from the fillers in Experiment 1.

\subsubsection{Procedure}

Participants were tested individually, and eye movements were recorded using an EyeLink 1000 eyetracker (SR Research, Mississauga, Ontario, Canada), interfaced with a Dell PC. The sampling rate for recordings was $1000 \mathrm{~Hz}$. Stimuli were displayed on a 23-inch Dell LCD monitor. Participants were seated approximately $97 \mathrm{~cm}$ from the computer screen. At this distance 6 characters subtended around $1^{\circ}$ of visual arc. The angular resolution of the eyetracker was 10-30 min of arc. Viewing was binocular, but only the right eye was recorded. Sentences were presented in 12 pt. fixed width Courier font. Each sentence was displayed on a single line.

The experiment was implemented using the Eye-Track software (http://www. psych.umass.edu/eyelab/software/). A calibration procedure was performed at the beginning of each testing session, and re-calibration was carried out between trials as needed. Each participant was instructed to read for comprehension in a normal manner. The participant triggered the onset of each sentence by fixating on a reference point on the left edge of the computer screen where the first word of the sentence was to appear. Each participant read three practice items before the experimental items were shown. Every experimental and filler item was followed by a yes/no comprehension question to ensure that participants were attending to the stimuli. Comprehension questions never referred to the referential dependency between the pronoun and its antecedent. The order of experimental and filler items was randomized across participants. The entire experimental session lasted approximately 45 minutes.

\subsubsection{Analysis}

The initial stages of data analysis were carried out using Eye Doctor (http://www. psych.umass.edu/eyelab/software/). We applied the same exclusion criteria and data cleaning procedures as in Experiment 1, which resulted in the exclusion of $0.18 \%$ of all trials. The same measures of interest and regions of analysis were used.

Following Experiment 1, the analysis included several nuisance variables as covariates to ensure that the results were not due to variability in skipping rates across conditions or differences between word frequency and length across items. For the pretarget region the nuisance variables included its character length and its interaction with the experimental effects of interest. The use of the region's length as a covariate was necessary because even though pronouns and determiners had equal length ("his" vs. "the") the pre-target region was lengthened by adding the complementizer "that" (in items that contained it) or the first three character spaces to the left of the pronoun/determiner (in 
items without a complementizer). Thus, the length of the pre-target region varied across items and thus it was entered as a factor in the analysis. For the target region the nuisance variables included (i) the length of the pre-target region, (ii) the length of the target region, (iii) the frequency of the target region, (iv) whether the pre-target region had been skipped or not. In addition, to ensure that our critical interaction between relatedness and determiner type in single fixation at the target word did not originate from an uneven distribution of fixations across items, the interaction between pre-target skipping rates and the experimental effects of interest was added to the model. All numeric predictors were centered before being entered in the analysis.

The random effects structure of the models included random intercepts and slopes for both experimental effects by participants and items. When the models failed to converge, we gradually simplified them following the guidelines in Barr, Levy, Scheepers, and Tily (2013). In the semantic conditions, non-convergence occurred in probability of regression at the target region. The simplified model removed the by-item slopes. In the phonological conditions, non-convergence occurred in first pass and total reading times at the pre-target region and in single fixation and first fixation in the target region. The simplified models removed the by-item slopes in the former case and the correlation between intercepts and slopes for both items and participants in the remaining cases.

\subsection{Results}

Average accuracy in the comprehension questions was $94.9 \%$ in the semantic conditions and $93.3 \%$ in the phonological conditions. Table 9 shows means and standard errors in the three regions of analysis across the reading time measures of interest. Pairwise comparisons and binomial measures are reported in the text. 
Table 9. Region averages and standard errors in milliseconds in Experiment 2 (English).

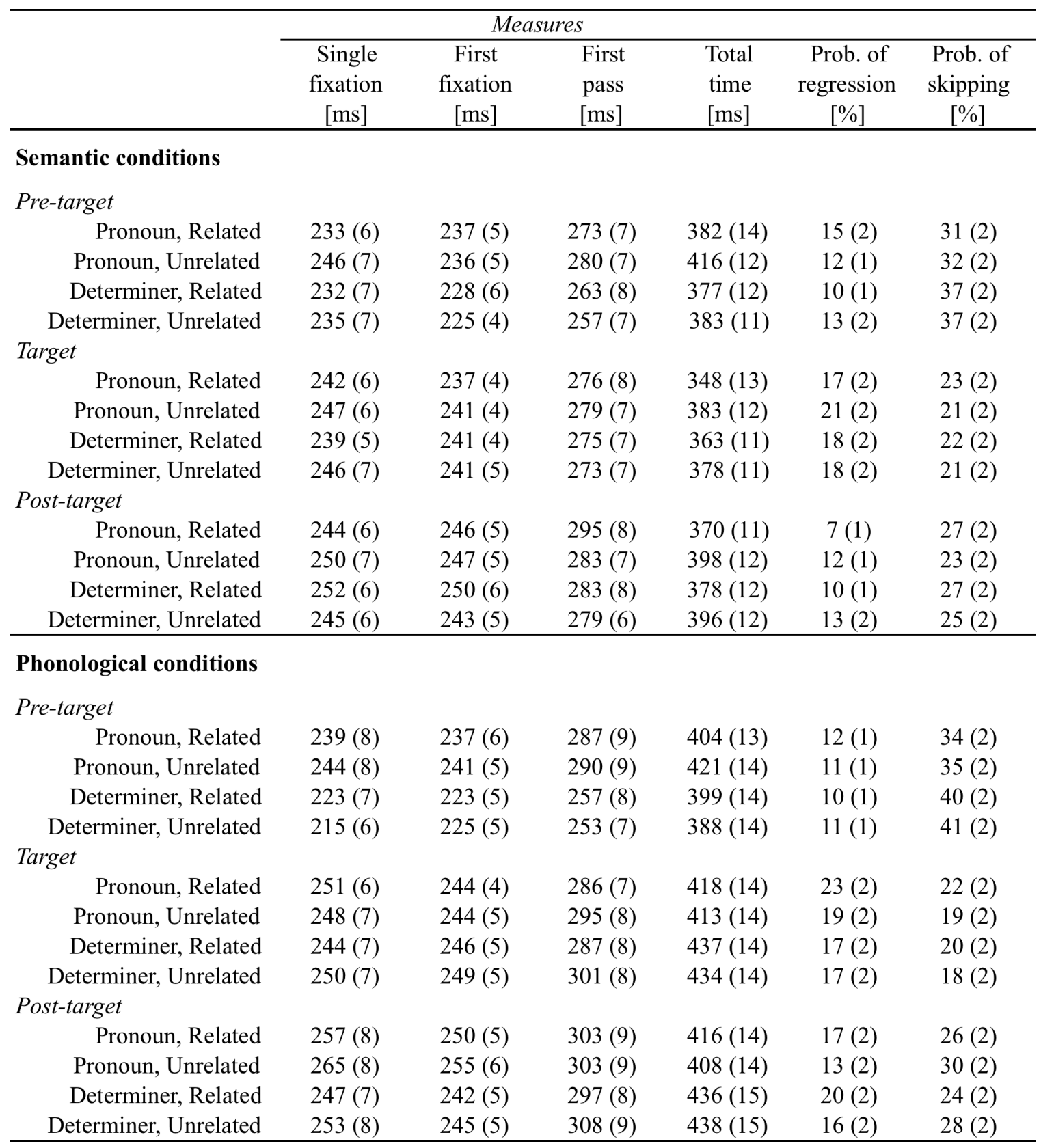

\subsubsection{Semantic conditions}

\section{Pre-target region}

Table 10 shows the mixed effects model results for the pre-target region. The pre-target region was skipped on $28.1 \%$ of trials. Early measures showed a main effect of determiner type: pronouns were read more slowly than determiners in first fixation, first pass and total reading times, and they also elicited fewer regressions. The probability of regression 
measure also showed a main effect of relatedness, with more regressions in the related than in the unrelated conditions, and an interaction between determiner type and relatedness. However, none of the pairwise comparisons reached significance (pronouns: $\hat{\beta}=0.42, S E$ $=0.33, z=1.23, p=.19$; determiners: $\hat{\beta}=-0.54, S E=0.31, z=-1.73, p=.08)$. As the interaction effect was unexpected in the pre-target region, we examine it in more detail in the Discussion. Finally, the analysis of the nuisance variables showed longer reading times, fewer regressions and lower skipping rates in longer regions. In addition, there was an interaction between determiner type and the length of the pre-target region in single fixation and first fixation times. The interaction was due to the effect of determiner type (i.e., longer reading times for pronouns than determiners) being smaller in longer than shorter regions.

Table 10. Linear mixed effects model estimates of logged reading times in Experiment 2 (English) in the semantic conditions at the pre-target region. For the determiner type factor, a positive estimate indicates that the pronoun conditions were read more slowly than the determiner conditions. For the relatedness factor, a positive estimate indicates that the related conditions were read more quickly than the unrelated conditions. Reliable effects at the $\alpha=.05$ level are in bold font.

\begin{tabular}{|c|c|c|c|c|c|c|c|c|c|}
\hline Pre-target region & $\beta$ & SE & $t / z$ & $p$ & & $\beta$ & SE & $t / z$ & $p$ \\
\hline Single fixation & & & & & Total times & & & & \\
\hline Length pre-target & 0.03 & 0.02 & 1.32 & .19 & & 0.06 & 0.02 & 2.44 & $<.05^{*}$ \\
\hline Determiner type & 0.07 & 0.04 & 1.79 & .07 & & 0.08 & 0.04 & 2.09 & $<.05^{*}$ \\
\hline Relatedness & -0.01 & 0.03 & -0.21 & .83 & & -0.03 & 0.04 & -0.91 & .36 \\
\hline Length pre-target $\times$ Det. type & -0.06 & 0.03 & -1.99 & $<.05^{*}$ & & -0.01 & 0.03 & -0.21 & .84 \\
\hline Length pre-target $\times$ Rel. & -0.03 & 0.03 & -1.12 & .26 & & 0.01 & 0.03 & 0.29 & .77 \\
\hline Det. type $\times$ Rel. & -0.08 & 0.05 & -1.72 & .09 & & -0.08 & 0.05 & -1.68 & .09 \\
\hline Length pre-target $\times$ Det. type $\times$ Rel. & 0.04 & 0.04 & 1.08 & .28 & & -0.02 & 0.04 & -0.55 & .58 \\
\hline First fixation & & & & & Prob. of regression & & & & \\
\hline Length pre-target & 0.03 & 0.02 & 1.68 & .10 & & -0.29 & 0.14 & -2.07 & $<.05^{*}$ \\
\hline Determiner type & 0.05 & 0.03 & 2.00 & $<.05^{*}$ & & -0.49 & 0.23 & -2.08 & $<.05^{*}$ \\
\hline Relatedness & 0.01 & 0.03 & 0.38 & .71 & & -0.55 & 0.24 & -2.32 & $<.05^{*}$ \\
\hline Length pre-target $\times$ Det. type & -0.04 & 0.02 & -2.08 & $<.05^{*}$ & & 0.20 & 0.19 & 1.03 & .30 \\
\hline Length pre-target $\times$ Rel. & -0.03 & 0.02 & -1.54 & .12 & & 0.19 & 0.19 & 1.01 & .31 \\
\hline Det. type $\times$ Rel. & -0.02 & 0.03 & -0.57 & .57 & & 0.99 & 0.30 & 3.30 & $<.05^{*}$ \\
\hline Length pre-target $\times$ Det. type $\times$ Rel. & 0.03 & 0.03 & 0.88 & .38 & & -0.17 & 0.27 & -0.65 & .52 \\
\hline First pass & & & & & Prob. of skipping & & & & \\
\hline Length pre-target & 0.04 & 0.02 & 2.07 & $<.05^{*}$ & & -0.49 & 0.12 & -3.96 & $<.05^{*}$ \\
\hline Determiner type & 0.09 & 0.03 & 2.71 & $<.05^{*}$ & & -0.21 & 0.18 & -1.15 & .25 \\
\hline Relatedness & 0.02 & 0.03 & 0.52 & .60 & & 0.22 & 0.17 & 1.30 & .19 \\
\hline Length pre-target $\times$ Det. type & -0.04 & 0.03 & -1.66 & .10 & & -0.08 & 0.16 & -0.48 & .63 \\
\hline Length pre-target $\times$ Rel. & 0.01 & 0.03 & 0.45 & .65 & & 0.03 & 0.15 & 0.21 & .84 \\
\hline Det. type $\times$ Rel. & -0.05 & 0.04 & -1.18 & .24 & & -0.24 & 0.23 & -1.04 & .30 \\
\hline Length pre-target $\times$ Det. type $\times$ Rel. & 0.01 & 0.04 & 0.34 & .74 & & 0.12 & 0.22 & 0.52 & .60 \\
\hline
\end{tabular}




\section{Target and post-target regions}

Table 11 shows the mixed effects model results for the target region and Table 12 shows the results for the post-target region. The target and post-target regions were skipped on $21.9 \%$ and $25.4 \%$ of trials. In early measures there was an interaction between pre-target skipping rates and determiner type at the target region. Pairwise comparisons revealed that the effect of determiner type (i.e., longer reading times for the pronoun than the determiner conditions) was only significant when the pre-target region was skipped. The analysis of the nuisance variables showed that reading times were often longer when the target word was longer or more infrequent. Further, when the pre-target word had been skipped, target words elicited longer total reading times, more regressions and lower skipping rates. No interactions between determiner type and relatedness were observed on any measure in the target region.

At the post-target region, related target words elicited longer total reading times and more regressions. Crucially, there was no interaction between relatedness and determiner type, showing that the effect of relatedness affected both pronouns and determiners. These results show that the semantic relationship between the target word and the antecedent led to faster reading times, but that semantic facilitation occurred for the pronoun and determiner conditions alike. Figure 2 displays the difference scores for comparison with Experiment 1. In early measures, neither pronouns nor determiners show evidence of priming and their difference scores cluster around 0 . In total reading times, both pronouns and determiners show a numeric tendency towards priming, similarly to Experiment 1. 
Figure 2. Semantic facilitation effects in the target region in Experiment 2 (English). Mean difference scores and their standard error are shown with squares and bars respectively. Difference scores were computed as the mean difference between the unrelated and related conditions for determiners (det) and pronouns (pro) separately. Positive scores index priming and negative scores index inhibition. Difference scores are plotted in milliseconds for easier interpretability, but all statistical comparisons were performed on logged reading times. Note that the vertical scales differ because they correspond to different eye-tracking measures.

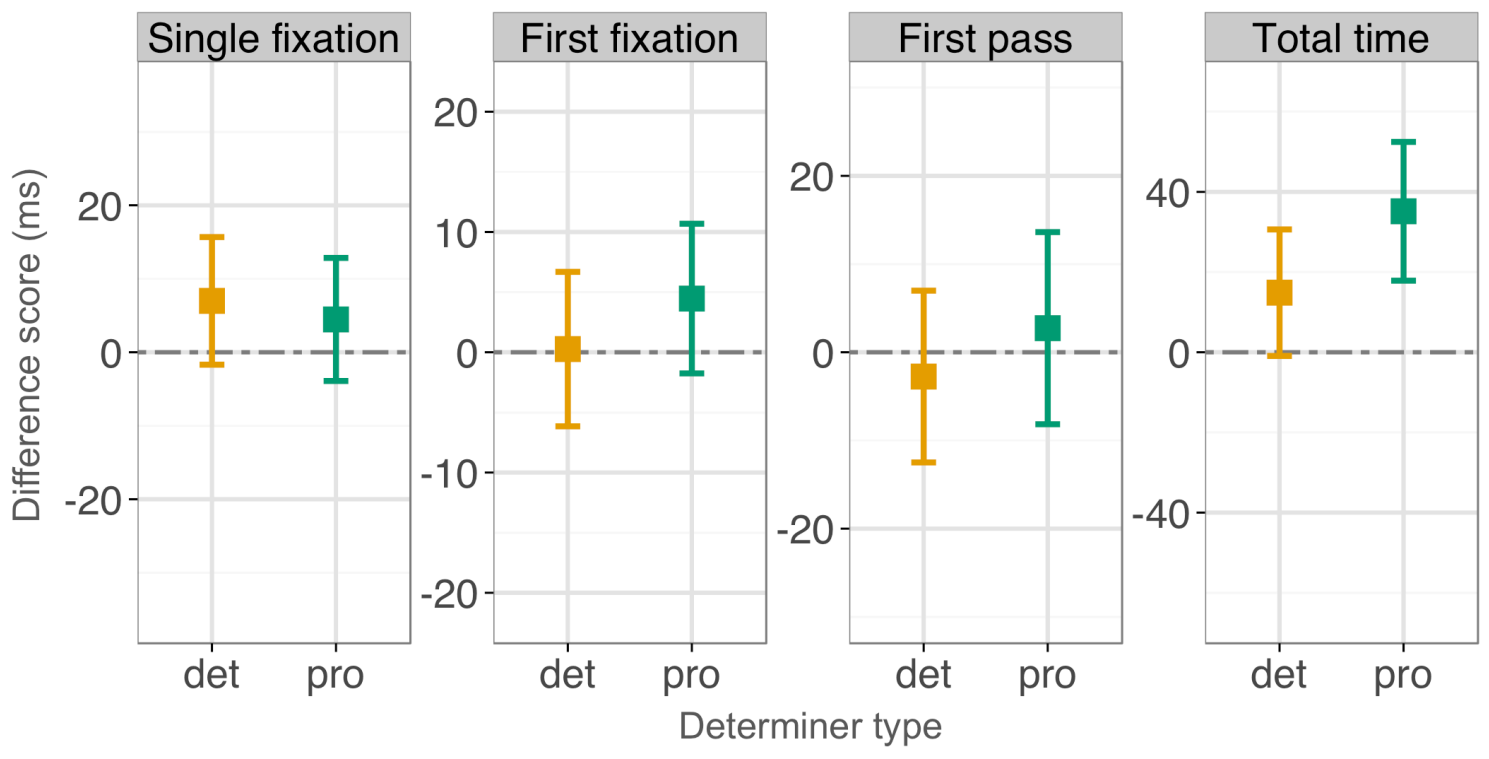


Table 11. Linear mixed effects model estimates of logged reading times in Experiment 2 (English) in the semantic conditions at the target region. For the determiner type factor, a positive estimate indicates that the pronoun conditions were read more slowly than the determiner conditions. For the relatedness factor, a positive estimate indicates that the related conditions were read more quickly than the unrelated conditions. Reliable effects at the $\alpha=.05$ level are in bold font.

\begin{tabular}{|c|c|c|c|c|c|c|c|c|c|}
\hline Target region & $\beta$ & SE & $t / z$ & $p$ & & $\beta$ & $\mathrm{SE}$ & $t / z$ & $p$ \\
\hline Single fixation & & & & & Total times & & & & \\
\hline Length pre-target & 0.01 & 0.01 & 0.66 & .51 & & 0.00 & 0.02 & -0.01 & .99 \\
\hline Length target & 0.01 & 0.01 & 0.94 & .35 & & 0.02 & 0.01 & 2.26 & $<.05^{*}$ \\
\hline Frequency target & -0.03 & 0.02 & -1.64 & .11 & & -0.08 & 0.03 & -3.09 & $<.05 *$ \\
\hline Skipping pre-target & 0.09 & 0.05 & 1.72 & .09 & & 0.18 & 0.05 & 3.28 & $<.05 *$ \\
\hline Determiner type & 0.04 & 0.04 & 1.07 & .28 & & 0.01 & 0.04 & 0.33 & .74 \\
\hline Relatedness & -0.02 & 0.04 & -0.51 & .61 & & -0.02 & 0.04 & -0.52 & .60 \\
\hline Skipping pre-target $\times$ Det. type & -0.06 & 0.07 & -0.84 & .40 & & -0.05 & 0.08 & -0.61 & .54 \\
\hline Skipping pre-target $\times$ Rel. & 0.04 & 0.07 & 0.65 & .52 & & -0.04 & 0.07 & -0.48 & .63 \\
\hline Det. type $\times$ Rel. & 0.01 & 0.05 & 0.27 & .79 & & -0.01 & 0.06 & -0.21 & .83 \\
\hline Skipping pre-target $\times$ Det. type $\times$ Rel. & -0.08 & 0.10 & -0.82 & .41 & & -0.10 & 0.11 & -0.94 & .35 \\
\hline First fixation & & & & & Prob. of regression & & & & \\
\hline Length pre-target & 0.01 & 0.01 & 0.87 & .39 & & 0.01 & 0.07 & 0.09 & .93 \\
\hline Length target & 0.00 & 0.00 & 0.15 & .88 & & -0.05 & 0.04 & -1.43 & .15 \\
\hline Frequency target & -0.02 & 0.01 & -1.43 & .16 & & -0.05 & 0.11 & -0.45 & .65 \\
\hline Skipping pre-target & 0.07 & 0.04 & 1.94 & .05 & & 1.39 & 0.30 & 4.69 & $<.05 *$ \\
\hline Determiner type & 0.04 & 0.03 & 1.52 & .13 & & 0.06 & 0.27 & 0.23 & .82 \\
\hline Relatedness & 0.00 & 0.03 & 0.14 & .89 & & 0.09 & 0.28 & 0.32 & .75 \\
\hline Skipping pre-target $\times$ Det. type & -0.12 & 0.05 & -2.33 & $<.05^{*}$ & & 0.09 & 0.41 & 0.22 & .83 \\
\hline Skipping pre-target $\times$ Rel. & 0.04 & 0.05 & 0.79 & .43 & & -0.60 & 0.41 & -1.44 & .15 \\
\hline Det. type $\times$ Rel. & -0.03 & 0.04 & -0.87 & .38 & & -0.19 & 0.36 & -0.53 & .60 \\
\hline Skipping pre-target $\times$ Det. type $\times$ Rel. & 0.02 & 0.07 & 0.23 & .82 & & 0.20 & 0.58 & 0.35 & .73 \\
\hline First pass & & & & & Prob. of skipping & & & & \\
\hline Length pre-target & 0.00 & 0.01 & -0.18 & .86 & & -0.05 & 0.06 & -0.80 & .42 \\
\hline Length target & 0.01 & 0.01 & 1.68 & .10 & & -0.26 & 0.04 & -6.44 & $<.05 *$ \\
\hline Frequency target & -0.05 & 0.02 & -2.73 & $<.05 *$ & & 0.31 & 0.10 & 3.06 & $<.05 *$ \\
\hline Skipping pre-target & 0.07 & 0.05 & 1.60 & .11 & & -1.05 & 0.32 & -3.24 & $<.05 *$ \\
\hline Determiner type & 0.04 & 0.04 & 1.27 & .21 & & 0.10 & 0.21 & 0.49 & .62 \\
\hline Relatedness & 0.02 & 0.04 & 0.46 & .65 & & 0.24 & 0.23 & 1.06 & .29 \\
\hline Skipping pre-target $\times$ Det. type & -0.11 & 0.06 & -1.71 & .09 & & -0.67 & 0.49 & -1.37 & .17 \\
\hline Skipping pre-target $\times$ Rel. & 0.02 & 0.06 & 0.34 & .73 & & 0.21 & 0.43 & 0.50 & .62 \\
\hline Det. type $\times$ Rel. & -0.04 & 0.05 & -0.73 & .46 & & -0.04 & 0.29 & -0.13 & .90 \\
\hline Skipping pre-target $\times$ Det. type $\times$ Rel. & 0.02 & 0.09 & 0.20 & .84 & & 0.26 & 0.64 & 0.41 & .68 \\
\hline
\end{tabular}


Table 12. Linear mixed effects model estimates of logged reading times in Experiment 2 (English) in the semantic conditions at the post-target region. For the determiner type factor, a positive estimate indicates that the pronoun conditions were read more slowly than the determiner conditions. For the relatedness factor, a positive estimate indicates that the related conditions were read more quickly than the unrelated conditions. Reliable effects at the $\alpha=.05$ level are in bold font.

\begin{tabular}{|c|c|c|c|c|c|c|c|c|c|}
\hline Post-target region & $\beta$ & SE & $t / \mathrm{z}$ & $p$ & & $\beta$ & $\mathrm{SE}$ & $t / \mathrm{z}$ & $p$ \\
\hline Single fixation & & & & & Total times & & & & \\
\hline Determiner type & 0.01 & 0.03 & 0.52 & .61 & & -0.02 & 0.03 & -0.61 & .54 \\
\hline Relatedness & 0.01 & 0.02 & 0.41 & .68 & & 0.06 & 0.03 & 2.33 & $<.05^{*}$ \\
\hline Det $\times$ Rel & 0.03 & 0.04 & 0.74 & .46 & & 0.02 & 0.05 & 0.50 & .62 \\
\hline First fixation & & & & & Prob. of regression & & & & \\
\hline Determiner type & 0.01 & 0.02 & 0.57 & .57 & & -0.24 & 0.22 & -1.10 & .27 \\
\hline Relatedness & -0.01 & 0.02 & -0.53 & .60 & & 0.50 & 0.19 & 2.64 & $<.05^{*}$ \\
\hline Det $\times$ Rel & 0.02 & 0.03 & 0.50 & .62 & & 0.29 & 0.38 & 0.75 & .45 \\
\hline First pass & & & & & Prob. of skipping & & & & \\
\hline Determiner type & 0.03 & 0.02 & 1.27 & .21 & & -0.15 & 0.14 & -1.03 & .30 \\
\hline Relatedness & -0.01 & 0.02 & -0.49 & .63 & & -0.16 & 0.14 & -1.15 & .25 \\
\hline Det $\times$ Rel & -0.02 & 0.04 & -0.49 & .62 & & -0.09 & 0.24 & -0.40 & .69 \\
\hline
\end{tabular}

\subsubsection{Phonological conditions}

Pre-target region

Table 13 shows the mixed effects model results for the pre-target region. The pre-target region was skipped on $30.2 \%$ of trials. Pronouns were read more slowly than determiners in single fixation, first pass and total reading times. The analysis of the nuisance variables revealed that longer regions elicited longer total reading times and lower skipping rates compared to shorter regions. 
Table 13. Linear mixed effects model estimates of logged reading times in Experiment 2 (English) in the phonological conditions at the pre-target region.

\begin{tabular}{|c|c|c|c|c|c|c|c|c|c|}
\hline Pre-target region & $\beta$ & $\mathrm{SE}$ & $t / z$ & $p$ & & $\beta$ & $\mathrm{SE}$ & $t / z$ & $p$ \\
\hline Single fixation & & & & & Total times & & & & \\
\hline Length pre-target & 0.02 & 0.02 & 0.73 & .47 & & 0.06 & 0.03 & 2.48 & $<.05^{*}$ \\
\hline Determiner type & 0.09 & 0.04 & 2.47 & $<.05 *$ & & 0.09 & 0.04 & 2.19 & $<.05 *$ \\
\hline Relatedness & 0.03 & 0.04 & 0.71 & .48 & & 0.02 & 0.04 & 0.53 & .60 \\
\hline Length pre-target $\times$ Det. type & 0.00 & 0.03 & -0.12 & .91 & & -0.04 & 0.03 & -1.25 & .21 \\
\hline Length pre-target $\times$ Rel. & -0.02 & 0.03 & -0.62 & .53 & & 0.00 & 0.03 & 0.09 & .93 \\
\hline Det. type $\times$ Rel. & -0.06 & 0.05 & -1.09 & .28 & & -0.07 & 0.05 & -1.24 & .22 \\
\hline Length pre-target $\times$ Det. type $\times$ Rel. & 0.03 & 0.04 & 0.71 & .48 & & 0.04 & 0.04 & 1.05 & .30 \\
\hline First fixation & & & & & Prob. of regression & & & & \\
\hline Length pre-target & 0.00 & 0.01 & 0.05 & .96 & & -0.11 & 0.12 & -0.86 & .39 \\
\hline Determiner type & 0.04 & 0.03 & 1.66 & .10 & & -0.11 & 0.22 & -0.51 & .61 \\
\hline Relatedness & -0.02 & 0.03 & -0.61 & .54 & & -0.39 & 0.25 & -1.57 & .12 \\
\hline Length pre-target $\times$ Det. type & -0.01 & 0.02 & -0.39 & .70 & & 0.00 & 0.17 & 0.03 & .98 \\
\hline Length pre-target $\times$ Rel. & 0.00 & 0.02 & -0.04 & .97 & & -0.16 & 0.17 & -0.92 & .36 \\
\hline Det. type $\times$ Rel. & 0.00 & 0.04 & 0.00 & 1.00 & & 0.26 & 0.30 & 0.86 & .39 \\
\hline Length pre-target $\times$ Det. type $\times$ Rel. & 0.01 & 0.03 & 0.53 & .60 & & 0.22 & 0.24 & 0.91 & .36 \\
\hline First pass & & & & & Prob. of skipping & & & & \\
\hline Length pre-target & 0.02 & 0.02 & 1.00 & .32 & & -0.45 & 0.09 & -5.02 & $<.05 *$ \\
\hline Determiner type & 0.10 & $\mathbf{0 . 0 3}$ & 2.90 & $<.05 *$ & & -0.30 & 0.16 & -1.81 & .07 \\
\hline Relatedness & 0.00 & 0.03 & 0.02 & .98 & & 0.00 & 0.16 & 0.01 & .99 \\
\hline Length pre-target $\times$ Det. type & 0.01 & 0.03 & 0.28 & .78 & & 0.03 & 0.13 & 0.24 & .81 \\
\hline Length pre-target $\times$ Rel. & 0.00 & 0.03 & 0.14 & .89 & & 0.08 & 0.12 & 0.65 & .52 \\
\hline Det. type $\times$ Rel. & -0.02 & 0.05 & -0.42 & .67 & & -0.04 & 0.22 & -0.17 & .87 \\
\hline Length pre-target $\times$ Det. type $\times$ Rel. & 0.01 & 0.04 & 0.20 & .84 & & -0.08 & 0.18 & -0.44 & .66 \\
\hline
\end{tabular}

\section{Target and post-target regions}

Table 14 shows the mixed effects model results for the target region and Table 15 shows the results for the post-target region. The target and post-target regions were skipped on $19.6 \%$ and $27.2 \%$ of trials respectively. There were no experimental effects of interest at the target or post-target regions. The analysis of the nuisance variables at the target region showed that reading times were longer when the target word was more infrequent or when the pre-target region was shorter. Further, when the pre-target region had been skipped, target words elicited longer first fixation and total reading times, more regressions and lower skipping rates. Lastly, the length of the pre-target region and length and frequency of the target regions reliably reduced skipping rates. None of these nuisance variables interacted with the experimental effects of interest. 
Table 14. Linear mixed effects model estimates of logged reading times in Experiment 2 (English) in the phonological conditions at the target region.

\begin{tabular}{|c|c|c|c|c|c|c|c|c|c|}
\hline Target region & $\beta$ & $\mathrm{SE}$ & $t / z$ & $p$ & & $\beta$ & $\mathrm{SE}$ & $t / z$ & $p$ \\
\hline Single fixation & & & & & Total times & & & & \\
\hline Length pre-target & -0.03 & 0.01 & -2.80 & $<.05^{*}$ & & -0.01 & 0.02 & -0.68 & .50 \\
\hline Length target & 0.00 & 0.01 & -0.26 & .80 & & 0.01 & 0.01 & 1.00 & .32 \\
\hline Frequency target & -0.02 & 0.02 & -0.96 & .34 & & -0.12 & 0.03 & -4.40 & $<.05 *$ \\
\hline Skipping pre-target & 0.08 & 0.05 & 1.66 & .10 & & 0.15 & 0.06 & 2.63 & $<.05 *$ \\
\hline Determiner type & 0.00 & 0.05 & 0.09 & .92 & & -0.02 & 0.05 & -0.37 & .71 \\
\hline Relatedness & -0.03 & 0.04 & -0.70 & .48 & & 0.01 & 0.05 & 0.31 & .76 \\
\hline Skipping pre-target $\times$ Det. type & -0.06 & 0.07 & -0.82 & .41 & & -0.12 & 0.08 & -1.53 & .13 \\
\hline Skipping pre-target $\times$ Rel & 0.01 & 0.07 & 0.09 & .93 & & 0.00 & 0.08 & -0.04 & .97 \\
\hline Det. type $\times$ Rel. & 0.05 & 0.06 & 0.84 & .40 & & -0.02 & 0.06 & -0.34 & .73 \\
\hline Skipping pre-target $\times$ Det. type $\times$ Rel. & -0.01 & 0.10 & -0.07 & .94 & & 0.14 & 0.11 & 1.25 & .21 \\
\hline First fixation & & & & & Prob. of regression & & & & \\
\hline Length pre-target & -0.01 & 0.01 & -1.64 & .10 & & 0.15 & 0.07 & 2.22 & $<.05 *$ \\
\hline Length target & -0.01 & 0.00 & -1.24 & .22 & & 0.02 & 0.05 & 0.51 & .61 \\
\hline Frequency target & -0.02 & 0.01 & -1.45 & .15 & & 0.21 & 0.12 & 1.80 & .07 \\
\hline Skipping pre-target & 0.08 & 0.04 & 2.16 & $<.05^{*}$ & & 1.00 & 0.29 & 3.49 & $<.05 *$ \\
\hline Determiner type & 0.00 & 0.03 & 0.08 & .94 & & 0.13 & 0.29 & 0.44 & .66 \\
\hline Relatedness & 0.00 & 0.03 & -0.09 & .93 & & -0.01 & 0.28 & -0.03 & .98 \\
\hline Skipping pre-target $\times$ Det. type & -0.04 & 0.05 & -0.86 & .39 & & -0.01 & 0.40 & -0.02 & .98 \\
\hline Skipping pre-target $\times$ Rel. & -0.02 & 0.05 & -0.51 & .61 & & -0.19 & 0.41 & -0.48 & .63 \\
\hline Det. type $\times$ Rel. & 0.00 & 0.04 & 0.12 & .90 & & 0.18 & 0.37 & 0.51 & .61 \\
\hline Skipping pre-target $\times$ Det. type $\times$ Rel. & 0.02 & 0.07 & 0.34 & .74 & & 0.79 & 0.57 & 1.39 & .16 \\
\hline First pass & & & & & Prob. of skipping & & & & \\
\hline Length pre-target & -0.01 & 0.01 & -1.45 & .15 & & -0.10 & 0.05 & -2.06 & $<.05 *$ \\
\hline Length target & 0.00 & 0.01 & 0.43 & .67 & & -0.27 & 0.04 & -7.28 & $<.05 *$ \\
\hline Frequency target & -0.07 & 0.02 & -4.31 & $<.05 *$ & & 0.36 & 0.09 & 4.19 & $<.05 *$ \\
\hline Skipping pre-target & 0.06 & 0.04 & 1.34 & .18 & & -1.23 & 0.32 & -3.83 & $<.05 *$ \\
\hline Determiner type & -0.01 & 0.04 & -0.20 & .85 & & 0.10 & 0.23 & 0.44 & .66 \\
\hline Relatedness & -0.04 & 0.04 & -1.03 & .30 & & 0.27 & 0.22 & 1.25 & .21 \\
\hline Skipping pre-target $\times$ Det. type & -0.05 & 0.06 & -0.74 & .46 & & 0.02 & 0.45 & 0.05 & .96 \\
\hline Skipping pre-target $\times$ Rel. & 0.01 & 0.06 & 0.12 & .91 & & -0.15 & 0.44 & -0.35 & .73 \\
\hline Det. type $\times$ Rel. & 0.01 & 0.05 & 0.19 & .85 & & 0.02 & 0.29 & 0.07 & .94 \\
\hline Skipping pre-target $\times$ Det. type $\times$ Rel. & 0.04 & 0.09 & 0.43 & 67 & & 0.10 & 0.62 & 0.16 & .87 \\
\hline
\end{tabular}


Table 15. Linear mixed effects model estimates of logged reading times in Experiment 2 (English) in the phonological conditions at the post-target region.

\begin{tabular}{|c|c|c|c|c|c|c|c|c|c|}
\hline Post-target region & $\beta$ & $\mathrm{SE}$ & $t / \mathrm{z}$ & $p$ & & $\beta$ & SE & $t / \mathrm{z}$ & $p$ \\
\hline Single fixation & & & & & Total times & & & & \\
\hline Determiner type & 0.03 & 0.03 & 1.22 & .23 & & -0.05 & 0.03 & -1.80 & .08 \\
\hline Relatedness & 0.02 & 0.03 & 0.81 & .42 & & -0.01 & 0.03 & -0.20 & .84 \\
\hline Det $\times$ Rel & 0.00 & 0.05 & 0.01 & .99 & & -0.02 & 0.05 & -0.36 & .72 \\
\hline First fixation & & & & & Prob. of regression & & & & \\
\hline Determiner type & 0.03 & 0.02 & 1.64 & .10 & & -0.28 & 0.17 & -1.65 & .10 \\
\hline Relatedness & 0.02 & 0.02 & 1.09 & .28 & & -0.19 & 0.15 & -1.23 & .22 \\
\hline Det $\times$ Rel & -0.02 & 0.04 & -0.66 & .51 & & -0.02 & 0.28 & -0.09 & .93 \\
\hline First pass & & & & & Prob. of skipping & & & & \\
\hline Determiner type & 0.01 & 0.02 & 0.42 & .68 & & 0.10 & 0.15 & 0.65 & .51 \\
\hline Relatedness & 0.03 & 0.02 & 1.11 & .27 & & 0.21 & 0.14 & 1.46 & .14 \\
\hline Det $\times$ Rel & -0.04 & 0.04 & -0.96 & .34 & & 0.01 & 0.24 & 0.05 & .96 \\
\hline
\end{tabular}

\subsection{Discussion}

We examined whether English speakers show rapid semantic and phonological antecedent reactivation effects during coreference. We reasoned that if the semantic facilitation seen for pronouns in Experiment 1 was due to the existence of syntactic gender, then this effect should be absent in English, which lacks syntactic gender. In contrast, under a discourse reactivation account, English and German speakers should show the same pattern of semantic facilitation, as reactivation of the pronoun's referent occurs in both languages. In addition, we examined whether there was evidence of reactivation of the phonological form of the antecedent during comprehension.

The findings of Experiment 2 differ from Experiment 1. English comprehenders showed no early semantic or phonological antecedent reactivation effects. Unlike German comprehenders, who showed rapid semantic effects in early measures, English comprehenders did not show early differences. However, later effects of semantic facilitation were observed for both pronouns and determiners in total reading times and probability of regression at the post-target region. Crucially, the lack of an interaction between semantic facilitation and determiner type suggests that priming effects impacted both pronouns and determiners.

Taken together, Experiments 1 and 2 show rapid semantic antecedent reactivation during coreference in German, but not in English. This difference supports the hypothesis that facilitation of semantically related words might occur in languages like German because it is tied to the reaccess of syntactic antecedent features such as grammatical gender. One implication of this view is that in English, reaccess to the referent of the pronoun does not, by itself, reactivate nouns semantically associated to the antecedent noun: for example, the retrieval of the concept of a singer in the discourse does not automatically prime the word "piano", as would occur if there were a spreading activation 
mechanism for discourse. This conclusion will be examined in the General Discussion. In what follows, we discuss two alternative accounts.

One possible explanation for the lack of semantic effects specific to the pronoun conditions in English is that there was a problem in the construction of the antecedenttarget noun pairs in English (e.g. "singer-piano"). Under this account, the German antecedent-target word pairs may have been more strongly associated than the English pairs, resulting in the lack of a semantic effect in English. However, this explanation seems unlikely because we did observe overall effects of semantic relatedness in English. In fact, main effects of relatedness at the post-target region were observed across languages in the same measure and with similar magnitude. This suggests that the antecedent-target noun pairs successfully elicited meaning associations in English and German. The specific contrast between these languages is that in English semantic effects were not specific to pronouns and occurred only in late reading measures.

A second concern is that the pre-target region was skipped more often in English than in German (28.1\% vs. $8.7 \%$ ). If the reduced number of fixations to pronouns indicates that comprehenders sometimes failed to process them, then antecedent reactivation may not have taken place on some trials thus explaining the absence of semantic facilitation. However, this explanation seems unlikely for two reasons. The first is that it relies on the assumption that lack of fixations to a region implies lack of processing of that region. But this does not follow, as short words are frequently processed parafoveally (Ehrlich \& Rayner, 1983; Garrod, Freudenthal, \& Boyle, 1994; van Gompel \& Majid, 2004). Second, we conducted a supplementary analysis including only the trials where the pre-target region was fixated, and we obtained qualitatively similar patterns with no interaction between relatedness and determiner type in either the target or the post-target regions. These results suggest that the lack of semantic facilitation in the pronoun conditions was not due to comprehenders' failure to process the pronoun.

Finally, the semantic conditions yielded an unexpected interaction between determiner type and relatedness in probability of regression at the pre-target region: there were numerically fewer regressions in the related than in the unrelated determiner conditions, whereas the converse was true for pronouns. At present, we do not have an explanation for these findings, as the pre-target region did not contain any semantic information, and it is unlikely that participants processed the meaning of the entire target word parafoveally: the existence of parafoveal-on-foveal semantic effects is controversial and there is no evidence that they extend to the semantic meaning of the entire previewed word (Schotter, Angele, \& Rayner, 2012; Rayner, 1998). Further, none of the pairwise comparisons in the pronoun and determiner conditions were significant and the effects did not persist in any critical region. Thus, we are unclear about their interpretation and reliability and we believe that more research will be necessary to address this issue. 


\section{General Discussion}

Our two eye-tracking experiments explored whether pronouns rapidly reactivate lexical semantic and phonological information about their antecedent during comprehension. We examined whether the type of reactivated information depended on the presence of syntactic gender by comparing German, a language with syntactic gender, and English, a language without it. In German, we found early semantic facilitation effects specific to pronouns (Experiment 1) whereas in English we did not (Experiment 2). In contrast, there was no evidence of phonological antecedent reactivation in either of these languages. We discuss each of these profiles in turn.

\section{Semantic effects}

Germans comprehenders showed facilitation in early measures when the word after a pronoun was semantically related to its antecedent. This supports a view where upon encountering a pronoun, German readers reaccess the lemma of the antecedent noun in the lexicon, which includes its syntactic and semantic features. The activation of the semantic features of the antecedent could in turn preactivate semantically related words, under a spreading activation mechanism (Collins \& Loftus, 1975; Forster, 1976; Levelt, Roelofs, \& Meyer, 1999; Morton, 1979). Consistent with this account, we found facilitated processing of the target word in single fixation and total reading times, and similar patterns were observed in first fixation and first pass times. Crucially, semantic facilitation was not observed in the determiner conditions. Thus, the source of the facilitation effect was likely due to the processing of coreference, and not merely to participants having read semantically related words in the preceding sentence, which was identical in the pronoun and determiner conditions.

In contrast, English speakers showed no evidence of semantic facilitation specific to coreference at the target or post-target regions. One explanation for the contrast between German and English is that the semantic relationship between the antecedent and the target word was weaker in English than in German, as shown by the relatedness norming task, where the difference between the related and unrelated pairs was 2.8 in English and 3.71 in German. We think that this explanation is unlikely because the antecedent and target words in English were judged as strongly related (on average 5.62 out of 7 points). Therefore, our ratings suggest that the semantic relationships in English were large enough that reactivation-based facilitation should have been observable in the eye-tracking experiment if it were indeed there. However, we cannot conclusively rule out that the lack of an effect specific to pronouns in English would have been observed with even more strongly related antecedent-target pairs. More research will be needed to address this possibility. 
The current study assessed the existence of semantic relatedness effects in German and English separately, instead of comparing the two languages directly. This was done to avoid comparing between experiments that differed in their participants and that used different antecedent-target word pairs, which could have confounded the strength of the semantic relations and other parameters across languages. By using within-language determiner controls, we could ensure that lexical differences and strength of association were identical for the experimental and control conditions (pronouns and determiners respectively). However, in order to provide statistical support for the contrasting profiles observed between German and English in the semantic conditions, we conducted an additional analysis on the relatedness difference scores in the pronoun conditions of Experiment 1 (German) and Experiment 2 (English). The by-subject difference scores (n $=60$ per language) at the target region in each of the four measures of interest (single fixation, first fixation, first pass and total reading times) were compared using a nonparametric test, the Wilcoxon signed-rank test (Bauer, 1972) with language (English vs. German) as a predictor. Our goal was to assess whether the difference scores in the pronoun conditions were significantly larger in German than in English. This was the case in single fixation $(\mathrm{p}<.05)$ and first pass $(\mathrm{p}<.05)$. The difference was marginal in first fixation $(\mathrm{p}=$ .09 ). In total time, there was not a significant difference between the German and English difference scores $(p=.16)$, consistent with the claim that German and English participants both showed relatedness effects in late measures.

We propose that the difference in the semantic conditions across English and German is due to the lack of syntactic gender in English. Specifically, coreference in English might not involve lexical retrieval of a pronoun's antecedent, because there is no additional benefit or requirement that comes from the antecedent's grammatical information. In terms of the lexical models outlined previously (e.g. Kempen \& Huijbers, 1983; Levelt, 1989; Levelt, Roelofs \& Meyer, 1999), English speakers might not reactivate the antecedent's lemma upon encountering a pronoun, which results in the lack of spreading activation to semantically related words.

In English, semantic facilitation affected the pronoun and determiner conditions in late reading measures at the post-target region. We suggest that these late effects reflect facilitation in later comprehension processes. Specifically, in sentences such as "The maintenance men told the singer/deputy about a problem. They had broken his piano and would have to repair that first", readers may have found it easier to incorporate "piano" to their discourse model when the first sentence mentioned a singer instead of a deputy. This is because singers are more related to pianos than deputies in the real world, such that 
accommodating the meaning of "piano" into an ongoing discourse representation should have been easier in the "singer" case, in both the pronoun and determiner conditions. ${ }^{2}$

We propose that in languages with syntactic gender, licensing a pronoun requires the retrieval of the grammatical gender of its antecedent noun in the lexicon. The gender of inanimate nouns such as "das Bild" ('the painting') is only grammatical and will be stored in the lexicon. The gender of animate nouns, such as "der Zeichenlehrer" ('the drawing teacher') is both conceptual and grammatical, such that pronouns will reactivate both the lexical entry and discourse representation of their antecedent noun. As grammatical gender is stored as part of a word's lemma, which includes both syntactic and semantic properties (Levelt, Roelofs \& Meyer, 1999), when the pronoun's antecedent is reactivated, speakers of languages with syntactic gender should have joint reaccess to its syntactic and semantic features. In contrast, phonological properties are stored at a different level, belonging to the word's lexeme, such that lemma and lexeme reactivation can occur independently and with different timecourses.

Interestingly, our English eye-tracking findings differ from previous cross-modal lexical decision experiments, which did find rapid semantic facilitation effects (Leiman, 1982; Shillcock, 1982). The question is why these studies obtained semantic facilitation to words presented immediately after pronouns, whereas we only observed these effects in late eye-tracking measures. One possibility is that such a contrast is due to a stronger use of explicit strategies in the cross-modal paradigm. In contrast with more implicit paradigms, lexical decision paradigms encourage participants to develop strategic processes, since detecting the semantic relationship between the target word and the antecedent can help them perform better in their lexical decisions (Neely, 1991). Therefore, participants in cross-modal studies may have developed a strategy to focus on semantic antecedent information in order to improve their performance in the task, as opposed to due to automatic reactivation.

Alternatively, the contrast across paradigms might be due to their different temporal resolution. Although both our studies and cross-modal experiments presented target words immediately after pronouns, the time elapsed after the presentation of the pronoun differed between tasks. For instance, in the study by Shillcock (Shillcock, 1982), lexical decisions to words after pronouns took on average $781 \mathrm{~ms}$ (unrelated: $824 \mathrm{~ms}$; related: $738 \mathrm{~ms}$ ). In our English study, participants spent on average $237 \mathrm{~ms}$ reading the pronoun, and $239 \mathrm{~ms}$

\footnotetext{
${ }^{2}$ Note that given the possibility that was raised earlier that the definite determiner predicted coreference to the antecedent NP ("the singer...They had broken the [singer] ...") an alternative account of these data might be that both pronouns and determiners showed semantic facilitation effects due to coreference. Although possible, we find this account unlikely. First, as noted earlier, repeating the earlier definite NP would have been pragmatically strange in many experimental items. Second, in cases where facilitation was observed for both pronouns and determiners, the magnitude of the facilitation effect was always larger for pronouns, which would be unexpected if both pronouns and definite NPs acted to reactivate the antecedent.
} 
reading the target word (first fixation related: $237 \mathrm{~ms}$; unrelated: $241 \mathrm{~ms}$ ). Thus, our experiment probed for semantic relationships approximately $476 \mathrm{~ms}$ after pronoun onset, which constitutes an earlier time window than the cross-modal paradigm. Of course, this estimate is too simplistic because it assumes that latencies in eye-tracking can be obtained by summing first fixation durations. But we provide the estimate not to establish absolute time points, but instead to suggest that the temporal contrast between tasks might provide access to different stages in pronoun resolution. Ongoing work from our group seems to support this idea, as we have recently found semantic effects at approximately $800 \mathrm{~ms}$ after pronoun onset in ERP measures using a sentence comprehension paradigm (Lago et al., in prep).

Finally, we think that the selectivity of our semantic facilitation effects can provide a useful tool to examine the interplay of discourse and lexical information during coreference. Specifically, we found that rapid effects of semantic association are only observed in a language where syntactic gender agreement constraints require comprehenders to retrieve a lexical antecedent representation. In contrast, reaccess of a pronoun's referent in the discourse did not result in rapid semantic association effects in a language without syntactic gender. This suggests that spreading activation of semantic information might only take place in the lexicon. Overall, although both the lexicon and the discourse encode semantic information, the mechanisms operating at these levels of representation might differ and might yield qualitative differences in information retrieval during comprehension.

\section{Phonological effects}

German comprehenders showed inhibition effects in the post-target region, with more regressions and longer fixations in the phonologically related conditions. This pattern suggests that our phonological manipulation was able to impact participants' eye movements but that phonological inhibition affected the pronoun and determiner conditions alike, which suggests that it was not due to antecedent retrieval. Instead, inhibition may have resulted from residual activation of the antecedent noun. When the antecedent word was read, its orthographic and phonological features should have become activated. If these representations had not fully decayed by the time the target word was read, they may have interfered with the processing of the target word, yielding inhibition effects.

The lack of phonological inhibition in the presence of semantic facilitation at the target region suggests that pronouns might initially reactivate the lemma but not the lexeme of an antecedent noun during comprehension. This might implicate a difference between the comprehension and the production systems, since in the production of German pronouns, inhibition effects have been previously found for words that were phonologically 
related to the pronoun's antecedent (Schmitt, Meyer \& Levelt, 1999; but see Jescheniak, Schriefers \& Hantsch, 2001).

A different explanation for the lack of phonological effects is that the lemmalexeme distinction corresponds to a difference in the timecourse of lexical retrieval. For instance, Levelt's model of production involves a 2-stage sequential architecture, where activation of a word's lexeme occurs after the activation of its lemma. Thus, the reactivation of the antecedent's form might have taken place after readers had already moved their gaze past the target word. At the post-target region, readers likely shifted their processing to the post-target word, which was not systematically related to the antecedent noun, and thus, was unlikely to elicit phonological interference. In other words, if inhibition effects are due to co-activation, they might not obtain if the phonology of the antecedent was activated too late, after readers' eyes had already moved to the following word. However, this account would seem to predict that delayed pronoun-specific phonological effects should have been observed in the post-target region, a pattern that we did not observe.

\section{Conclusion}

We used eye movement patterns during reading to examine the retrieval of semantic and phonological antecedent information in German and English. We hypothesized that the existence of syntactic gender in German, but not in English, could influence the type of information retrieved during pronoun comprehension. In German, comprehenders showed evidence of rapid semantic facilitation, in the absence of phonological effects. In contrast, English comprehenders did not show immediate effects of either semantic or phonological antecedent reactivation. We proposed that early semantic facilitation effects might be due to the reactivation of syntactic gender in the lexical entry of a pronoun's antecedent. In contrast, coreference in English might not involve lexical retrieval, because there is no additional benefit or requirement that comes from the antecedent's grammatical information. Taken together, these results suggest that antecedent retrieval during online processing depends on the type of information relevant to the grammar of each language. 


\section{Bibliography}

Baayen, R.H., Davidson, D.J., \& Bates, D.M. (2008) Mixed-effects modeling with crossed random effects for subjects and items. Journal of Memory and Language, 59, 390412.

Baayen, H. R., Piepenbrock, R., \& Van Rijn, H. (1993). The CELEX lexical database. Philadelphia, PA: Linguistic Data Consortium, University of Pennsylvania. Available from WebCelex at http://celex.mpi.nl/.

Bates, D., Maechler, M., Bolker, B., \& Walker, S. (2015). lme4: Linear mixed-effects models using Eigen and S4. http://CRAN.R-project.org/package=lme4.

Barr D.J., Levy R., Scheepers C., \& Tily, H. (2013) Random-effects structure for confirmatory hypothesis testing: Keep it maximal. Journal of Memory and Language, 68, 255-278.

Bauer, D.F. (1972), Constructing confidence sets using rank statistics. Journal of the American Statistical Association, 67, 687-690.

Cacciari, C., Carreiras, M., \& Barbolini-Cionini, C. (1997). When words have two genders: Anaphor resolution for Italian functionally ambiguous words. Journal of Memory and Language, 37, 517-532.

Camblin, C.C., Gordon, P.C., \& Swaab, T.Y. (2007). The interplay of discourse congruence and lexical association during sentence processing: Evidence from ERPs and eye tracking. Journal of Memory \& Language, 56, 103-128.

Carreiras, M., Garnham, A., \& Oakhill, J. (1993). The use of superficial and meaningbased representations in interpreting pronouns. Evidence from Spanish. European Journal of Cognitive Psychology, 5, 93-116.

Carroll, P., \& Slowiaczek, M. L. (1986). Constraints on semantic priming in reading: A fixation time analysis. Memory \& Cognition, 14, 509-522.

Chow, W.C., Lewis, S., \& Phillips, C. (2014). Immediate structural constraints on pronoun resolution. Frontiers in Psychology, 5: 630. doi: 10.3389/fpsyg.2014.00630.

Cloitre, M. \& Bever, T.G. (1988). Linguistic anaphors, levels of representation, and discourse. Language \& Cognitive Processes, 3, 293-322.

Collins, A.M., \& Loftus, E.F. (1975). A spreading-activation theory of semantic processing. Psychological Review, 82, 407-428.

Ehrlich, K. (1983). Eye movements in pronoun assignment: A study of sentence integration. In K. Rayner (Ed.), Eye movements in reading: Perceptual and language processes. New York: Academic Press.

Forster, K.I. (1976). “Accessing the mental lexicon”. In R.J. Wales \& E. Walker (eds), New Approaches to Language Mechanisms, Amsterdam: North Holland.

Frazier, L., Henstra, J. \& Flores d' Arcais, G.B. (1996). Finding candidate antecedents: Phrase or Conceptual Entities. University of Massachusetts Occasional Papers in Linguistics, 19,193-238. 
Garnham, A. (2001). Mental models and the interpretation of anaphora. East Sussex: Psychology Press.

Garnham, A., Oakhill, J., Erlich, M. F., \& Carreiras, M. (1995). Representations and processes in the interpretation of pronouns: New evidence from Spanish and French. Journal of Memory and Language, 34, 41-62.

Garrod, S., Freudenthal, D. \& Boyle, E. (1994). The role of different types of anaphor in the on-line resolution of sentences in discourse. Journal of Memory and Language, 33, 39-68.

Heim, I. (1988). The Semantics of Definite and Indefinite Noun Phrases. Garland Publishers: New York.

Ito, A., Corley, M, Pickering, M. J., Martin, A. E., \& Nieuwland, M. S. (2016). Predicting form and meaning: Evidence from brain potentials. Journal of Memory and Language, 86, 157-171.

Jescheniak, J. D., Schriefers, H., \& Hantsch, A. (2001). Semantic and phonological activation in noun and pronoun production. Journal of Experimental Psychology: Learning, Memory, and Cognition, 27, 1058-1078.

Kempen, G., \& Huijbers, P. (1983). The lexicalisation process in sentence production and naming: indirect election of words. Cognition, 14, 185-209.

Kuznetsova, A., Bruun Brockhoff, P., \& Haubo Bojesen Christensen, R. (2014). lmerTest: Tests for random and fixed effects for linear mixed effect models (lmer objects of lme4 package). $\mathrm{R}$ package version 2.0-6. http://CRAN.Rproject.org/package $=$ lmerTest.

Leiman, J.M. (1982). A chronometric analysis of referent assignment to pronouns. Ph.D. dissertation, Wayne State University, Detroit, Michigan.

Levelt, W. J. M. (1989). Speaking: from intention to articulation. Cambridge, MA: MIT Press.

Levelt, W. J. M., Roelofs, A., \& Meyer, A. S. (1999). A theory of lexical access in speech production. Behavioral and Brain Sciences, 22, 1-75.

Lucas, M.M., Tanenhaus, M.K., \& Carlson, G. N. (1990). Levels of representation in the interpretation of anaphoric reference and instrument inference. Memory and Cognition, 18, 611-631.

McKoon, G., \& Ratcliff, R. (1981). The comprehension processes and memory structures involved in instrumental inference. Journal of Verbal Learning and Verbal Behavior, 20, 671-682.

McKoon, G., Ratcliff, R., \& Ward, G. (1994). Testing theories of language processing: An empirical investigation of the on-line lexical decision task. Journal of Experimental Psychology: Learning, Memory, and Cognition, 20, 1219-1228.

Meyer, A. S., \& Bock, K. (1999). Representations and processes in the production of pronouns: Some perspectives from Dutch. Journal of Memory and Language, 41, 281-30. 
Morris, R. K., \& Folk, J. R. (1998). Focus as a contextual priming mechanism in reading. Memory \& Cognition, 26, 1313-1322.

Morton, J. (1979). "Word Recognition". In J. Morton \& J.C. Marshall (eds.), Psycholinguistics Series, vol. 2, Structures and Processes. London: Elek.

Neely, J. H. (1991). Semantic priming effects in visual word recognition: A selective review of current findings and theories. In D. Besner \& G. Humphreys (eds.), Basic processes in reading: Visual word recognition, (pp. 264-336). Hillsdale, N. J.: Erlbaum.

Nicol, J.L., Fodor, J.D. \& Swinney, D.A. (1994). Using cross-modal lexical decision tasks to investigate sentence processing. Journal of Experimental Psychology: Learning, Memory, and Cognition, 20, 1229-1238.

Paterson, K.B., Liversedge, S.P., \& Davis, C.J. (2009) Inhibitory neighbor priming effects in eye movements during reading. Psychonomic Bulletin \& Review, 16, 43-50.

Paterson, K., Alcock, A., \& Liversedge, S.P. (2011) Morphological priming during reading: evidence from eye movements. Language and Cognitive Processes, 26, 600-623.

Schmitt, B.M., Meyer, A.S. \& Levelt, W.J.M. (1999). Lexical access in the production of pronouns. Cognition, 69, 313-335.

Schotter, E.R., Angele, B., \& Rayner, K. (2012). Parafoveal processing in reading. Attention, Perception \& Psychophysics, 74, 5-35.

Shillcock, R. (1982). The on-line resolution of pronominal anaphora. Language and Speech, 25, 385-401.

van Gompel, R.P.G. \& Majid, A. (2004). Antecedent frequency effects during the processing of pronouns. Cognition, 90, 255-264.

Van Turennout, M., Hagoort, P. \& Brown, C. M. (1997) Electrophysiological evidence on the time course of semantic and phonological processes in speech production. Journal of Experimental Psychology: Learning, Memory, and Cognition, 23, 787806. 


\section{Supplemental materials - "Coreference and antecedent representation across languages"}

http://dx.doi.org/10.1037/xlm0000343

\section{() Materials used in Experiments 1 and 2}

\section{Experiment 1: German}

The experiment contained 64 item sets of 8 conditions. Comprehension questions are only included in the phonological conditions when they differed from the questions used in the semantic conditions. The fillers were adaptations of the fillers in Experiment 2, and thus their translations are available on pages 45-53.

\section{Semantic conditions}

1. Die Nachbarinnen mochten den Zeichenlehrer/Administrator, der im obersten Stockwerk wohnte. Sie fanden, dass sein/das Bild, an dem er in seiner Freizeit gearbeitet hatte und das jetzt im Hausflur hing, sehr gut geworden war.

The neighbors liked the drawing teacher/administrator, who lived on the top floor. They found that his/the painting, on which he had worked in his spare time and which now hung in the hall, had become very good.

Hing das Bild im Hausflur? Y

Did the picture hang in the hallway?

2. Die Hausfrauen lobten den Konditor/Algerier, der ein neues Geschäft in der Nachbarschaft eröffnete. Sie meinten, dass sein/das Gebäck, das er verkaufte, sehr gut war.

The housewives praised the baker/Algerian, who was opening a new shop in the neighborhood. They thought that his/the pastries, that he sold, were very good.

Meinten die Hausfrauen, dass das Gebäck nicht gut war? N

Did the housewives think that the pastries were not very good?

3. Die Kolleginnen bemitleideten den Optiker/Pendler, der an einem entzündeten Blinddarm litt. Sie hatten gehört, dass seine/die Brille, ohne die er nichts sehen konnte, im Krankenhaus verloren gegangen war.

The colleagues pitied the optician/commuter, who had an inflamed appendix. They had heard that his/the glasses, without which he was not able to see anything, had been lost in the hospital.

War die Brille im Krankenhaus verloren gegangen? Y 
Had the glasses been lost in the hospital?

4. Die Tiertrainerinnen baten den Wärter/Zoologen, mehr auf die Sicherheit des Zoos zu achten. Sie sahen, dass seine/die Schlüssel, die er sonst am Gürtel trug, heruntergefallen waren und wiesen ihn darauf hin.

The animal trainers asked the keeper/zoologist to pay more attention to the security of the zoo. They saw that his/the keys, which he usually wore on his belt, had fallen off and pointed this out to him.

Hat der Wärter Zoologe auf die Sicherheit des Zoos geachtet? N

Did the keeper/zoologist pay attention to the zoo's security?

5. Die Mädchen bewunderten den Wachmann/Dompteur, der makellos aussah. Sie fanden, dass seine/die Uniform, die er zur Arbeit trug, ihm sehr gut stand.

The girls admired the guard/animal tamer, who looked flawless. They thought that his/the uniform that he wore to work looked very good on him.

Bewunderten die Mädchen den Wachmann Dompteur? Y

Did the girls admire the guard/animal tamer?

6. Mehrere Zuhörerinnen sprachen den Redner/Piloten nach der Pressekonferenz an. Sie fragten, ob seine/die Notizen, die er sich gemacht hatte, online veröffentlicht würden.

Several listeners talked to the speaker/pilot after the press conference. They asked if his/the notes that he had taken would be published online.

Gingen die Zuhörerinnen direkt nach der Pressekonferenz? N

Did the listeners leave right after the press conference?

7. Die Verlegerinnen unterhielten sich mit dem Autor/Leiter, der etwas veröffentlichen wollte. Sie fragten, ob sein/das Manuskript, an dem er immer noch arbeitete, bald fertig sein würde.

The publishers talked to the author/leader, who wanted to publish something. They asked if his/the manuscript, which he was still working on, would be ready soon.

Arbeitete der Autor/Leiter noch an dem Manuskript? Y

Was the author/leader still working on the manuscript?

8. Die Besitzerinnen trafen den Kontrolleur/Auktionator, der die Ware begutachten wollte. Sie baten, dass seine/die Formulare, die er noch vollständig ausfüllen musste, ihnen bald zugesandt würden. 
The owners met with the inspector/auctioneer who wanted to inspect the goods. They asked that his/the forms, which he still had to complete, were sent to them soon.

Hatte der Kontrolleur/Auktionator die Formulare vollständig ausgefüllt? N

Had the inspector/auctioneer finished filling in the forms?

9. Die Kassiererinnen riefen nach dem Fleischer/Kapellmeister, der schon am Gehen war. Sie wussten, dass sein/der Schinken, den er hatte zurücklegen lassen, noch an der Kasse lag.

The cashiers called after the butcher/bandleader, who was already leaving. They knew that his/the ham, which he had reserved, was still at the cash register.

Lag der Schinken noch an der Kasse? Y

Was the ham still at the cash register?

10. Die Produktionsassistentinnen waren gleich zur Stelle, nachdem der

Handwerker/Komponist seine Arbeit beendet hatte. Sie sahen, dass seine/die Säge, die er zum Aufbau der Bühne benötigt hatte, leider kaputt gegangen war.

The production assistants were there immediately after the handyman/composer had finished his work. They saw that his/the saw, which he had needed for setting up the stage, had unfortunately broken.

War die Säge noch heile? N

Was the saw still fine?

11. Die Mieterinnen baten den Hausmeister/Metallarbeiter nach Vollendung des Umbaus zu putzen. Sie sagten, dass sein/der Besen in der Abstellkammer zu finden sei.

The tenants asked the janitor/metalworker to clean up after finishing the renovations. They said that his/the broom could be found in the closet.

Baten die Mieterinnen den Hausmeister/Metallarbeiter zu putzen? Y

Did the tenants ask the janitor/metalworker to clean up?

12. Die Inspektorinnen verärgerten den Bauern/Franzosen bei der Besichtigung des Hofs. Sie kritisierten, dass sein/der Traktor, der noch ganz neu war, nicht den Vorschriften entsprach.

The inspectors angered the farmer/Frenchman during the inspection of the farm. They criticized that his/the tractor, which was still very new, did not comply with the regulations 
War der Traktor schon alt? N

Was the tractor already old?

13. Die Sekretärinnen baten den Studenten/Mitarbeiter, die Unterlagen rechtzeitig zu bearbeiten. Sie hofften, dass sein/der Professor, der das Projekt leitete, dann zufrieden sein würde.

The secretaries asked the student/co-worker to complete the forms on time. They hoped that his/the professor who was in charge of the project would then be satisfied.

Hofften die Sekretärinnen, dass der Professor zufrieden sein würde? Y

Did the secretaries hope that the professor would be satisfied?

14. Die Frauen grüßten den Hufschmied/Juniorchef im Vorbeigehen. Sie bemerkten, dass sein/das Pferd, auf dem er häufig ausritt, etwas nervös wirkte.

The women greeted the blacksmith/junior partner in passing. They noticed that his/the horse, which he frequently rode, seemed a little nervous.

Ritt der Hufschmied/Juniorchef auf einem Esel? N

Was the blacksmith/junior partner riding a donkey?

15. Die Besitzerinnen verhandelten mit dem Kellner/Mieter, bevor der Mietvertrag unterschrieben wurde. Sie stellten sicher, dass sein/das Restaurant, das hoch verschuldet war, ihn nicht am Zahlen hindern würde.

The owners negotiated with the waiter/tenant before signing the lease. They made sure that his/the restaurant, which was in a lot of debt, would not prevent him from making payments.

War das Restaurant hoch verschuldet? Y

Was the restaurant in a lot of debt?

16. Die Kundinnen dankten dem Mechaniker/Verwalter am Telefon. Sie sagten, dass sein/das Auto, das er ihnen geliehen hatte, sehr gut fuhr.

The customers thanked the mechanic/administrator on the phone. They said that his/the car, which he had lent them, drove very well.

Beschwerten sich die Kundinnen beim Mechaniker/Verwalter? N

Did the customers complain to the mechanic/administrator?

17. Die Journalistinnen kannten den Kritiker/Theologen sehr gut. Sie erwarteten, dass seine/die Rezension, die er vor kurzem geschrieben hatte, zu interessanten Diskussionen führen würde. 
The journalists knew the critic/theologist very well. They expected that his/the review, which he had recently written, would lead to interesting discussions.

Dachten die Journalistinnen, dass die Rezension zu interessanten Diskussionen führen würde? Y

Did the journalists think that the review would lead to interesting discussions?

18. Die Kolleginnen machten sich über den Trainer/Forscher lustig, als das Spiel endete. Sie sahen, dass seine/die Sportschuhe, auf die er so stolz war, mit Schlamm überzogen waren.

The colleagues made fun of the trainer/researcher when the game was over. They saw that his/the gym shoes of which he was so proud were covered in mud.

Waren die Sportschuhe sauber? N

Were the gym shoes clean?

19. Die Spaziergängerinnen sprachen mit dem Tierarzt/Apotheker, der immer im Park spazieren ging. Sie versicherten, dass sein/der Hund, der immer mit dabei war, ein äußerst schönes Tier sei.

The ramblers talked to the vet/pharmacist who always went for walks in the park. They assured him that his/the dog, which was always with him, was an exceptionally beautiful animal.

Ging der Tierarzt/Apotheker immer im Park spazieren? J

Did the vet/pharmacist always go for walks in the park?

20. Die Mädchen redeten gerne mit dem Schwimmer/Taxifahrer, der immer in das Sportstudio gegenüber kam. Sie sagten, dass seine/die Badehose, die jedes Mal seinen Körper zierte, ein schönes Muster hatte.

The girls liked to chat with the swimmer/taxi driver who always went to the gym across the street. They said that his/the swimming trunks, which always adorned his body, had a very nice pattern.

War die Badehose einfarbig? N

Were the swimming trunks unicolored?

21. Die Besucherinnen gaben dem Hotelier/Anfänger eine schlechte Rückmeldung. Sie beschwerten sich, dass seine/die Rezeption schmutzig und mit Papier vollgestopft war.

The visitors gave the hotelier/beginner a bad review. They complained that his/the reception was dirty and cluttered with paper. 
War die Rezeption mit Papier vollgestopft? Y

Was the reception cluttered with paper?

22. Die Managerinnen dankten dem Verkäufer/Erfinder, der den Kundenservice verbessert hatte. Sie sagten, dass seine/die Kasse, an der er lange gearbeitet hatte, allen viel Zeit gespart hatte.

The managers thanked the salesman/inventor, who had improved the costumer service. They said that his/the cash register on which he had worked for a long time had saved everyone a lot of time.

Dankte der Verkäufer/Erfinder den Managerinnen? N

Did the salesman/inventor thank the managers?

23. Die Kolleginnen berieten den Zahnarzt/Exporteur, der an starken

Kopfschmerzen litt. Sie sagten, dass seine/die Weisheitszähne, die er vor kurzem bekommen hatte, sich wahrscheinlich entzündet hatten.

The colleagues gave advise to the dentist/exporter, who was suffering from severe headaches. They said that his/the wisdom teeth, which had recently come in, had probably become infected.

Hatte der Zahnarzt/Exporteur Kopfschmerzen? Y

Was the dentist/exporter suffering from headaches?

24. Die Assistentinnen benachrichtigten den Schauspieler/Sozialisten, als alles bereit war. Sie sagten, dass sein/der Monolog, den er so lange geübt hatte, bestimmt gut ankommen würde.

The assistants notified the actor/socialist when everything was ready. They said that his/the monologue, which he had practiced for so long, would definitely be well received.

Dachten die Assistentinnen, dass der Monolog schlecht ankommen würde? N

Did the assistants think that the monologue would be received badly?

25. Die Polizistinnen hielten den Fahrer/Spieler am Zebrastreifen an. Sie kritisierten, dass sein/das Lenkrad und die Rückscheinwerfer in einem sehr schlechten Zustand waren.

The policewomen stopped the driver/player at the crosswalk. They criticized that his/the steering wheel and the taillights were in very poor condition.

Waren die Rückscheinwerfer in einem schlechten Zustand? Y

Were the taillights in poor condition? 
26. Die Vermieterinnen sprachen mit dem Bäcker/Jockey über die Beschwerden der anderen. Sie sagten, dass sein/der Ofen, wenn zu heiß aufgedreht, die Hauswände erwärme und die Nachbarn zu sehr ins Schwitzen bringe.

The landladies talked to the baker/jockey about the others' complaints. They said that his/the oven, when turned up too high, was heating up the walls of the house and made the neighbors sweat too much.

Sagten die Vermieterinnen, dass der Ofen kein Problem für die Nachbarn wäre? N Did the landladies say that the oven was no problem for the neighbors?

27. Die Seniorinnen mochten den Arzt/Freund aufgrund seines Wissens. Sie wussten, dass seine/die Untersuchung, die immer mit größter Genauigkeit durchgeführt wurde, stets zu einem guten Ergebnis führte.

The seniors liked the doctor/friend because of his knowledge. They knew that his/the examination, which was always done with great care, always led to good results.

Mochten die Seniorinnen den Arzt/Freund wegen seines Wissens? Y

Did the seniors like the doctor/friend because of his knowledge?

28. Die Hausfrauen grüßten den Briefträger/Steuerberater jeden Morgen. Sie hofften, dass sein/das Paket, das er unter dem Arm trug, für sie war.

The housewives greeted the postman/tax accountant every morning. They hoped that his/the package, which he was carrying under his arm, was for them.

Wussten die Hausfrauen, dass das Paket nicht für sie war? N

Did the housewives know that the package was not for them?

29. Die Moderatorinnen sprachen mit dem Stadtrat/Ausländer über Immigrationspolitik. Sie sagten, dass seine/die Pressekonferenz, bei der er menschliches Miteinander einforderte, die Menschen sehr berührt habe.

The moderators spoke to the city councilman/foreigner about immigration policy. They said that his/the press conference, at which he had made a plea for better coexistence, had really touched people.

Hatte die Pressekonferenz die Menschen berührt? Y

Did the people feel touched by the press conference?

30. Die Freundinnen kritisierten den Nachrichtensprecher/Geschichtsschreiber nach dem Abendessen. Sie dachten, dass seine/die Ansage, dass er sich an eine strenge Diät halten wolle, nicht ernst zu nehmen sei. 
The friends criticized the news anchor/storyteller after dinner. They thought that his/the announcement that he would go on a strict diet should not be taken seriously.

Glaubten die Freundinnen, dass die Ansage bezüglich einer strengen Diät ernst zu nehmen sei? $\mathrm{N}$

Did the friends think that the announcement regarding the strict diet should be taken seriously?

31. Die Inspektorinnen zeigten den Bewohner/Fischer an, nachdem mehrere Mängel gefunden worden waren. Sie fanden, dass sein/das Haus in einem sehr schlechten Zustand war.

The inspectors reported the inhabitant/fisher after several defects were found. They thought that his/the house was in very bad condition.

Zeigten die Inspektorinnen den Bewohner/Fischer an? Y

Did the inspectors report the inhabitant/fisher?

32. Die Nachbarinnen lobten den Klempner/Bassisten bei der Hauseinweihungsfeier. Sie fanden, dass seine/die Rohre in allen Zimmern sehr gut verputzt worden waren und man sie kaum sehen konnte.

The neighbors complimented the plumber/bassist at the housewarming party. They thought that his/the pipes had been very well plastered in all the rooms and were hardly visible.

Kritisierten die Nachbarinnen den Klempner/Bassisten? N

Did the neighbors criticize the plumber/bassist?

33. Die Moderatorinnen ließen den Anwalt/Senator nicht zu Ende sprechen. Sie erklärten, dass sein/der Einspruch nicht berechtigt sei.

The moderators did not let the lawyer/senator finish speaking. They explained that his/the objection was not justified.

Fanden die Moderatorinnen den Einspruch berechtigt? N

Did the moderators think the objection was justified?

34. Mehrere Besucherinnen beschwerten sich über den Priester/Herzog nach einer öffentlichen Rede. Sie fanden, dass seine/die Kirchengemeinde solche Ansichten nicht dulden sollte.

Several visitors complained about the priest/duke after a public speech. They thought that his/the congregation should not tolerate such views. 
Beschwerten sich mehrere Besucherinnen nach der öffentlichen Rede? Y

Did several visitors complain after the public speech?

35. Die Mädchen riefen hinter dem Bibliothekar/Fernfahrer her, der dabei war zu gehen. Sie hatten bemerkt, dass sein/das Buch, in das er bis eben so vertieft gewesen war, auf einer Bank liegengeblieben war.

The girls called after the librarian/trucker who was about to leave. They had noticed that his/the book, which he had been so absorbed in, had been left on a bench.

War das Buch auf einer Bank liegengeblieben? Y

Had the book been left on a bench?

36. Die Bankkauffrauen telefonierten mit dem Abteilungsleiter/Parteimitglied wegen der finanziellen Schwierigkeiten. Sie fragten, ob seine/die Angestellten, die schon lange für ihn arbeiteten, eine Lohnkürzung akzeptieren würden.

The bankers talked to the manager/party member on the phone about the financial difficulties. They asked if his/the employees, who had been working for him for a long time, would accept a pay cut.

Arbeiteten die Angestellten erst seit kurzem für den Abteilungsleiter/das Parteimitglied? N

Had the employees been working for the manager/party member for only a short time?

37. Die Sekretärinnen wunderten sich über den Programmierer/Sprachforscher, der sonst immer gute Arbeit leistete. Sie wussten nicht, dass sein/der Computer, auf den er für seine Arbeit angewiesen war, kaputt war.

The secretaries were surprised about the programmer/linguist who usually did good work. They didn't know that his/the computer, which he relied on for his work, was broken.

War der Computer kaputt? Y

Was the computer broken?

38. Die Kellnerinnen ignorierten den Anglisten/Cellisten, der häufig ins Café kam. Sie fanden, dass seine/die Übersetzung der Speisekarte ins Englische, mit der er sie beeindrucken wollte, lächerlich war.

The waitresses ignored the anglicist/cellist who frequently visited the cafe. They thought that his/the translation of the menu into English, which he tried to impress them with, was ridiculous. 
Bewunderten die Kellnerinnen den Anglisten/Cellisten? N

Did the waitresses admire the anglicist/cellist?

39. Die Professorinnen widersprachen dem Rechenkünstler/Anlageberater in Bezug auf seine Darlegung. Sie behaupteten, dass sein/der Taschenrechner eine Fehlfunktion haben müsse.

The professors disagreed with the math genius/investment consultant about his explanation. They claimed that his/the calculator must have been malfunctioning.

Widersprachen die Professorinnen der Darlegung? Y

Did the professors disagree with the explanation?

40. Alle Aktivistinnen unterstützten den Produzenten/Intellektuellen aus voller Überzeugung. Sie meinten, dass sein/der Film, an dem er mit vielen anderen zusammen gearbeitet hatte, eine wichtige Botschaft hatte.

All the activists whole-heartedly supported the producer/intellectual. They thought that his/the movie on which he had collaborated with a lot of other people had an important message.

Dachten die Aktivistinnen, dass der Film sinnlos war? N

Did the activists think that the movie was pointless?

41. Die Investorinnen ärgerten sich sehr über den Unternehmer/Nachfolger, der bei dem Meeting vorgestellt wurde. Sie dachten, dass sein/der Geschäftsplan, der vorgeschlagen wurde, schlecht durchdacht war.

The investors were very angry at the entrepreneur/successor who was introduced at the meeting. They thought that his/the business plan, which was proposed, was not well thought-through.

Wurde der Unternehmer/Nachfolger bei dem Meeting vorgestellt? Y

Was the entrepreneur/successor introduced at the meeting?

42. Die Feriengäste beschwerten sich bei dem Bauarbeiter/Landwirt wegen des Hauses. Sie sagten, dass sein/das Gerüst, das vor kurzem aufgestellt worden war, die Aussicht ruinierte.

The holiday visitors complained to the builder/farmer about the house. They said that the scaffold, which had been put up recently, ruined the view.

Waren die Feriengäste mit der Aussicht zufrieden? N

Were the holiday visitors happy with the view? 
43. Die Reporterinnen interviewten den Verteidiger/Innenminister nach dem Skandal. Sie berichteten, dass sein/das Plädoyer gegen die Entscheidung für sehr viel Aufsehen gesorgt hatte.

The journalists interviewed the defense lawyer/Secretary of State after the scandal. They reported that his/the plea against the decision had caused a stir.

Hatte das Plädoyer für Aufsehen gesorgt?

Did the plea create a stir?

44. Die Hausfrauen begrüßten den Fotografen/Gesandten, der gerade aus den Ferien zurückgekommen war. Sie fragten, ob seine/die Kamera, die er neu gekauft hatte, gut funktioniert hatte und wollten Bilder sehen.

The housewives greeted the photographer/ambassador who had just come back from vacation. They asked if his/the camera, which he had recently bought, had worked well and wanted to see pictures.

War der Fotograf/Gesandte schon lange aus den Ferien zurück? N Had the photographer/ambassador been back from vacation for a while?

45. Die Wählerinnen kritisierten den Kommunisten/Politiker, der zum Minister ernannt worden war. Sie meinten, dass sein/das Stalinporträt in seinem Büro als Wandschmuck unangebracht sei.

The voters criticized the communist/politician who had been appointed minister. They thought that his/the portrait of Stalin was inappropriate as wall decoration in his office.

Dachten die Wählerinnen, dass das Stalinporträt unangebracht sei? Y

Did the voters think that the portrait of Stalin was inappropriate?

46. Die Sekretärinnen beruhigten den Uhrmacher/Veteranen am Telefon. Sie versprachen, dass sein/das Vergrößerungsglas, das er extra bestellt hatte, bald geliefert werde würde.

The secretaries calmed down the watchmaker/veteran on the phone. They promised that his/the magnifying glass, which he had specifically ordered, would be delivered soon.

Sagten die Sekretärinnen, dass die Lieferung des Vergrößerungsglases noch lange dauern würde? N

Did the secretaries say that the delivery of the magnifying glass would take a long time? 
47. Die Verkäuferinnen berieten den Kassierer/Methodisten beim Kauf einer neuen Stereoanlage. Sie garantierten, dass sein/das Geld für das beste Modell reichen würde.

The sales-assistants advised the cashier/Methodist regarding the purchase of a new stereo set. They guaranteed that his/the money would be enough for the best model.

Berieten die Verkäuferinnen den Kassierer/Methodisten beim Kauf? Y

Did the sales-assistants advise the cashier/Methodist regarding the purchase?

48. Die Mitbewohnerinnen begannen, sich über den Frisör/Barmann zu ärgern, der erst vor kurzem eingezogen war. Sie fanden, dass sein/der Haarschnitt, von dem er so begeistert war, ihn arrogant aussehen ließ.

The housemates were beginning to be annoyed with the hairdresser/bartender who had moved in only recently. They thought that his/the haircut, which he was so enthusiastic about, made him look arrogant.

Mochten die Mitbewohnerinnen den Haarschnitt des Frisörs/Barmanns? N

Did the housemates like the hairdresser's/bartender's haircut?

49. Die Juristinnen verhörten den Jäger/Häftling während der Verhandlung. Sie fragten, ob sein/das Gewehr während des Vorfalls geladen gewesen sei.

The lawyers cross-examined the hunter/prisoner during the trial. They asked if his/the rifle had been loaded at the time of the incident.

Wollten die Juristinnen wissen, ob das Gewehr geladen gewesen sei? Y

Did the lawyers want to know if the rifle had been loaded?

50. Die Reiseleiterinnen redeten mit dem Taucher/Pächter während der Exkursion. Sie versprachen, dass sein/der Schnorchel, den er benutzte, geprüft und sicher sei.

The tour guides talked to the diver/tenant during the excursion. They promised that his/the snorkel which he used had been tested and was safe.

Versprachen die Reiseleiterinnen, dass der Schnorchel sicher sei? Y

Did the tour guides promise that the snorkel was safe?

51. Die Sekretärinnen unterhielten sich mit dem Akademiker/Bauherrn als das Telefon klingelte. Sie sagten, dass sein/der Vortrag, den er gestern gehalten hatte, sehr gelobt worden war. 
The secretaries were talking to the academic/contractor when the phone rang. They said that his/the talk, which he had given the previous day, had been highly praised.

Sagten die Sekretärinnen, dass der Vortrag kritisiert worden war? N

Did the secretaries say that the talk had been criticized?

52. Die Studentinnen besuchten den Architekten/Historiker bei der Arbeit. Sie hatten gehört, dass sein/das Gebäude, in dem er ein Büro hatte, unter Denkmalschutz stand und sehr interessant war.

The students visited the architect/historian at work. They had heard that his/the building in which he had an office was listed and was very interesting.

Besuchten die Studentinnen den Architekten/Historiker zu Hause? N Did the students visit the architect/historian at home?

53. Mehrere Journalistinnen interviewten den Richter/Kanzler nach der Pressekonferenz. Sie unterstellten, dass sein/das Urteil in der Angelegenheit durch seine eigenen Interessen kompromittiert war.

Several journalists interviewed the judge/chancellor after the press conference. They claimed that his/the judgment regarding the matter had been compromised by his conflict of interest.

Unterstellten die Journalistinnen, dass das Urteil kompromittiert sei? Y Did the journalists claim that the judgment had been compromised?

54. Die Reporterinnen interviewten den Reiter/Sportler nach dem Rennen. Sie bewunderten seinen/den Sattel, den er bei dem Derby benutzt hatte, weil er so außergewöhnlich war.

The journalists interviewed the rider/athlete after the race. They admired his/the saddle, which he had used in the derby, because it was so exceptional.

Interviewten die Reporterinnen den Reiter/Sportler vor dem Rennen? N

Did the journalists interview the rider/athlete before the race?

55. Die Studentinnen befragten den Regisseur/Experten hinsichtlich der CastingAuswahl. Sie bezweifelten, dass sein/der Kameramann die beste Wahl für den Film gewesen sei.

The students asked the director/expert about the casting choices. They doubted that his/the cameraman had been the best choice for the film. 
Dachten die Studentinnen, dass der Kameramann nicht die beste Wahl gewesen sei? Y

Did the students think that the cameraman had not been the best choice?

56. Die Personalmanagerinnen kritisierten den Statisten/Ökonom, der Probleme hatte, Anweisungen zu folgen. Sie warnten, dass sein/der Auftritt am vorherigen Tag ihn möglicherweise sogar seinen Job kosten könnte.

The human resources managers criticized the extra/economist who had trouble following directions. They warned that his/the performance the previous day might even cost him his job.

Konnte der Statist/Ökonom sich gut an Anweisungen halten? N Was the statistician/economist good at following directions?

57. Die Putzfrauen kritisierten den Komponisten/Besitzer nach der Reinigung des Theatersaals. Sie sagten, dass seine/die Noten, mit denen er gestern geübt hatte, überall herumlagen.

The cleaning ladies criticized the composer/owner after cleaning the theatre hall. They said that his/the musical score, which he had used to practice the previous day, was scattered everywhere.

Lagen die Noten überall herum? Y

Was the score scattered everywhere?

58. Die Freundinnen luden den Matrosen/Raucher ein auf die kleine Insel mitzukommen. Sie sagten, dass sein/das Boot, das er eigentlich verkaufen wollte, sie dorthin bringen könnte.

The friends invited the sailor/smoker to accompany them to the small island. They said that his/the boat, which he was actually planning to sell, could take them there.

Lud der Matrose/Raucher die Freundinnen auf die Insel ein? N

Did the sailor/smoker invite the friends to the island?

59. Die Frauen mochten den Inhaber/Helfer, der beim Tragen der Einkaufstüten half. Sie besuchten seinen/den Laden, in dem er sich immer aufhielt, um sich zu bedanken.

The women liked the owner/helper who helped carry their shopping bags. They visited his/the store he was always in to thank him.

Half der Inhaber/Helfer beim Tragen der Einkaufstüten? Y 
Did the owner/helper help carry the shopping bags?

60. Die Nachbarinnen trafen den Rentner/Gelehrten auf dem Weg nach Hause. Sie sagten, dass seine/die Enkelkinder, die mit ihm spazieren gingen, sehr wohlerzogen waren.

The neighbors met the pensioner/scholar on the way home. They said that his/the grand children, who were taking a walk with him, were very well-behaved.

Sagten die Nachbarinnen, dass die Enkelkinder sich schlecht benahmen? N

Did the neighbors say that the grandchildren were badly behaved?

61. Die Sekretärinnen rieten dem Vermieter/Chauffeur, die Bank zu kontaktieren. Sie sagten, dass seine/die Wohnung, auf die er einen Kredit aufnehmen wollte, erst besichtigt werden müsste.

The secretaries advised the landlord/chauffeur to contact the bank. They said that his/the apartment, which he wanted to mortgage, had to be inspected first.

Wollte der Vermieter/Chauffeur einen Kredit auf seine Wohnung aufnehmen? Y Did the landlord/chauffeur want to take a mortgage out on his apartment?

62. Die Kolleginnen mochten den Redakteur/Manager für den Sportbereich. Sie fanden, dass seine/die Zeitschrift, die er betreute, sehr lesenswert war.

The colleagues liked the editor/manager of the sports section. They thought that his/the magazine, which he was in charge of, was well worth reading.

Hassten die Kolleginnen den Redakteur/Manager für den Sportbereich? N Did the colleagues hate the editor/manager of the sports section?

63. Die Soldatinnen bezahlten den Trommler/Söldner, an der Parade teilzunehmen. Sie hofften, dass seine/die Pauke, die er mitbringen wollte, die Menge aufheitern würde.

The soldiers paid the drummer/mercenary to take part in the parade. They hoped that his/the drum, which he was bringing, would cheer up the crowd.

Bezahlten die Soldatinnen den Trommler/Söldner an der Parade teilzunehmen? Y Did the soldiers pay the soldier/mercenary to participate in the parade?

64. Die Organisatorinnen baten den Karikaturenzeichner/Langstreckenläufer, die Siegerurkunde auszufüllen. Sie bemerkten, dass sein/der Stift, den er aus seiner Tasche zog, schmierte. 
The organisers asked the cartoonist/long-distance runner to fill out the winner's certificate. They noticed that his/the pen, which he pulled from his pocket, smudged.

Zog der Karikaturenzeichner/Langstreckenläufer den Stift hinter seinem Ohr hervor? $\mathrm{N}$

Did the cartoonist/long-distance runner pull the pen from behind his ear?

\section{Phonological conditions}

1. Die Nachbarinnen mochten den Zeichenlehrer/Administrator, der im obersten Stockwerk wohnte. Sie gingen sicher, dass seine/die Zeitung nicht aus seinem Briefkasten geklaut wurde.

The neighbors liked the drawing teacher/administrator, who lived on the top floor. They made sure that his/the newspaper did not get stolen from his mailbox.

Wohnte der Zeichenlehrer/Administrator im untersten Stockwerk? N

Did the drawing teacher/administrator live on the lowest floor?

2. Die Kundenberaterinnen beruhigten den Konditor/Algerier, dessen Kreditkarte gestohlen worden war. Sie sagten, dass sein/das Konto gesperrt worden sei und er sich keine Sorgen machen müsse.

The customer-service representatives calmed down the baker/Algerian, whose credit card had been stolen. They said that his/the bank account had been frozen and he did not have to worry.

War das Konto gesperrt worden? Y

Had the bank account been frozen?

3. Die Kolleginnen bemitleideten den Optiker/Pendler, der an einem entzündeten Blinddarm litt. Sie wussten, dass seine/die Operation direkt bevorstand und wollten ihn beruhigen.

The colleagues pitied the optician/commuter, who had an inflamed appendix. They knew that his/the surgery was coming up and wanted to calm him down. Hatte der Optiker/Pendler die Operation schon hinter sich? N Had the optician/commuter already had the surgery?

4. Die Tiertrainerinnen hatten Mitleid mit dem Wärter/Zoologen, der starke Rückenschmerzen hatte. Sie hofften, dass seine/die Wärmflasche die Beschwerden etwas lindern würde. 
The animal trainers felt sorry for the keeper/zoologist, who had sever back pain. They hoped that his/the hot water bottle would alleviate the pain a little bit.

Hofften die Tiertrainerinnen, dass die Wärmflasche die Rückenschmerzen lindern würde? Y

Did the animal trainers hope that the hot water bottle would alleviate the back pain?

5. Die Mädchen riefen den Wachmann/Dompteur, als ein wilder Hund angerannt kam. Sie hofften, dass seine/die Waffen, die er immer bei sich trug, sie beschützen würden.

The girls called for the guard/animal tamer when a wild dog came running. They hoped that his/the weapons, which he always carried, would protect them.

Spielten die Mädchen mit dem wilden Hund? N

Did the girls play with the wild dog?

6. Mehrere Zuhörerinnen sprachen den Redner/Piloten an, der die Veranstaltung verließ. Sie sahen, dass sein/die Regenschirm, den er unter dem Arm trug, kaputt war.

Several listeners talked to the speaker/pilot, who left the event. They saw that his/the umbrella, which he was carrying under his arm, was broken.

War der Regenschirm kaputt? Y

Was the umbrella broken?

7. Die Organisatorinnen baten den Autor/Leiter, pünktlich zu sein. Sie wussten, dass sein/das Auto, das er erst vor kurzem gekauft hatte, kaputt war und er ein Taxi gerufen hatte.

The organizers asked the author/leader to be on time. They knew that his/the car, which he had only recently bought, was broken and he had called a taxi.

War es den Organisatorinnen egal, ob der Autor/Leiter pünktlich war? N

Did the organizers not care if the author/leader was on time?

8. Die Ärztinnen berieten den Kontrolleur/Auktionator, der gesünder leben wollte. Sie bemängelten, dass seine/die Kondition, die er bei dem Fitnesstest gezeigt hatte, sehr schlecht war.

The doctors gave advice to the inspector/auctioneer who wanted to live more healthily. They criticized that his/the stamina he had shown during the fitness test was very bad. 
Wollte der Kontrolleur/Auktionator gesünder leben? Y

Did the inspector/auctioneer want to live more healthily?

9. Die Kassiererinnen riefen nach dem Fleischer/Kapellmeister, der schon dabei war zu gehen. Sie wussten, dass seine/die Flasche Wein, die er hatte zurücklegen lassen, noch an der Kasse stand.

The cashiers called after the butcher/bandleader, who was already leaving. They knew that his/the bottle of wine, which he had reserved, was still at the cash register.

Hatte der Fleischer/Kapellmeister den Wein schon mitgenommen? N

Had the butcher/bandleader already picked up the wine?

10. Die Frauen auf dem Laufband drehten sich nach dem Handwerker/Komponisten um, als ein lautes Krachen zu hören war. Sie hofften, dass seine/die Hanteln, mit denen er trainierte, nicht wieder auf den Boden gefallen war.

The women on the treadmill turned towards the handyman/composer when there was a loud noise. They hoped that his/the dumbbells, which he had been training with, had not been dropped on the floor again.

Trainierte der Handwerker/Komponist mit Hanteln? Y

Was the handyman/composer training with dumbbells?

11. Die Mieterinnen hörten den Hausmeister/Metallarbeiter fluchen, als das Treppenhaus gereinigt wurde. Sie befürchteten, dass seine/die Haut, die nicht durch Handschuhe geschützt war, durch das ätzende Putzmittel verletzt worden war.

The tenants heard the janitor/metalworker swear when the staircase was being cleaned. They feared that his/the skin, which was not protected by gloves, had been damaged by the corrosive cleaning agent.

Trug der Hausmeister/Metallarbeiter Handschuhe? N

Was the janitor/metalworker wearing gloves?

12. Die Inspektorinnen verärgerten den Bauern/Franzosen bei der Besichtigung des Hofs. Sie sagten, dass sein/der Baum, der im Vorgarten stand, gefällt werden müsste, weil die Wurzeln den Bürgersteig beschädigten.

The inspectors angered the farmer/Frenchman during the inspection of the farm. They said that his/the tree, which was in the front yard, had to be cut down because the roots were damaging the sidewalk.

Verärgerten die Inspektorinnen den Bauern/Franzosen? Y 
Did the inspectors anger the farmer/Frenchman?

13. Die Dozentinnen warnten den Studenten/Mitarbeiter, der versuchte bei der Klausur abzuschreiben. Sie hatten bemerkt, dass sein/der Stuhl viel zu nah an seinem Banknachbarn stand.

The lecturers warned the student/co-worker who was trying to cheat on the exam. They had noticed that his/the chair was way too close to his neighbor's.

Warnten die Professorinnen den Studenten/Mitarbeiter? Y

Did the professors warn the student/co-worker?

14. Die Frauen grüßten den Hufschmied/Juniorchef im Vorbeigehen. Sie riefen, dass sein/der Hut, den er neu gekauft hatte, ihm sehr gut stand.

The women greeted the blacksmith/junior partner in passing. They shouted that his/the hat, which he had newly bought, looked very good on him.

Fanden die Frauen den neuen Hut hässlich? N

Did the women think the new hat was ugly?

15. Die Umzugshelferinnen verhandelten mit dem Kellner/Mieter bevor der Umzug began. Sie hatten gesehen, dass sein/der Keller mit Kisten vollgestellt war und verlangten mehr Geld.

The movers negotiated with the waiter/tenant before the move. They had seen that his/the basement was full of boxes and demanded more money.

Verhandelten die Umzugshelferinnen mit dem Kellner/Mieter nach dem Umzug? $\mathrm{N}$

Did the movers negotiate with the waiter/tenant after the move?

16. Die Kundinnen dankten dem Mechaniker/Verwalter am Telefon. Sie bestätigten, dass seine/die Meldung sehr wichtig war und es richtig gewesen war, sie sofort anzurufen.

The customers thanked the mechanicladministrator on the phone. They confirmed that his/the message was very important and it had been the right thing to call them immediately.

War die Meldung wichtig gewesen? Y

Was the message important?

17. Die Freundinnen kannten den Kritiker/Theologen sehr gut. Sie wussten, dass seine/die Krise, die er gerade durchmachte, nicht leicht zu überwinden sein würde. 
The friends knew the critic/theologist very well. They knew that his/the crisis he was experiencing would not be easy to get through.

Dachten die Freundinnen, dass die Krise leicht zu überwinden sein würde? N Did the friends think that the crisis would be easy to get through?

18. Die Kolleginnen umarmten den Trainer/Forscher, als das Spiel zu Ende war. Sie sahen, dass seine/die Tränen, die die Wangen herunterflossen, ehrlich waren.

The colleagues hugged the trainer/researcher when the game was over. They saw that his/the tears, which were streaming down his cheeks, were honest.

Umarmten die Kolleginnen den Trainer/Forscher? Y

Did the colleagues hug the trainer/researcher?

19. Die Kellnerinnen sprachen mit dem Tierarzt/Apotheker, der auf die Bestellung wartete. Sie versicherten, dass sein/das Tiramisu bald kommen würde und fragten, ob er noch etwas anderes wünschte.

The waitresses talked to the vet/pharmacist who was waiting for the order. They ensured him that his/the tiramisu would be there soon and asked if there was anything else he would like.

Sagten die Kellnerinnen, dass das Tiramisu leider alle war? N

Did the waitresses say that they were out of tiramisu?

20. Die Köchinnen konnten den Schwimmer/Taxifahrer gut leiden, der häufig zum Mittagessen kam. Sie stellten sicher, dass sein/der Schweinebraten, den er so gerne mochte, stets bereit war, wenn er vorbeikam.

The cooks liked the swimmer/taxi driver, who frequently came for lunch. They made sure that his/the roast pork, which he liked so much, was always ready when he came by.

Kam der Schwimmer/Taxifahrer häufig zum Mittagessen? Y

Did the swimmer/taxi driver often come for lunch?

21. Die Zimmermädchen warnten den Hotelier/Anfänger, dass die Hotelleitung großen Wert auf ein gepflegtes Äußeres legte. Sie starrten auf seine/die Hose, die am Knie ein Loch hatte.

The maids warned the hotelier/beginner that the hotel's management put great emphasis on a neat appearance. They stared at his/the trousers, which had a hole in the knee.

War die Hose des Hoteliers/Anfängers in einem guten Zustand? N 
Were the hotelier's/beginner's trousers in good condition?

22. Die Managerinnen lobten den Verkäufer/Erfinder, als die Inventur beendet war. Sie versprachen, dass sein/der Vertrag definitiv verlängert werden würde.

The managers praised the salesman/inventor when the stocktaking was done. They promised that his/the contract would definitely be renewed.

Versprachen die Managerinnen, dass der Vertrag verlängert werden würde? Y

Did the managers promise that the contract would be renewed?

23. Die Kundenberaterinnen telefonierten mit dem Zahnarzt/Exporteur wegen der Lieferung des neuen Behandlungsstuhls. Sie sagten, dass seine/die Zahlung noch nicht bei ihnen eingetroffen sei.

The customer service representatives talked to the dentist/exporter on the phone about the delivery of the new treatment chair. They said that they had not received his/the payment yet.

War die Zahlung schon eingetroffen? N

Had they received the payment?

24. Die Krankenschwestern kümmerten sich um den Schauspieler/Sozialisten in der Klinik. Sie gingen sicher, dass sein/die Schaumbad die perfekte Temperatur erreicht hatte, bevor er in die Wanne stieg.

The nurses took care of the actor/socialist at the clinic. They made sure that his/the bubble bath was the perfect temperature before he got in the bathtub. War der Schauspieler/Sozialist in einer Klinik?

Was the actor/socialist at a clinic?

25. Die Fußgängerinnen starrten den Fahrer/Spieler an, als das Auto auf dem Parkplatz hielt. Sie dachten, dass seine/die Fahne an dem Wagen sicher die anderen Verkehrsteilnehmer ablenken würde.

The pedestrians stared at the driver/player when the car stopped in the parking lot. They thought that his/the flag on the car would surely be distracting to the other drivers.

Mochten die Fußgängerinnen die Fahne? N

Did the pedestrians like the flag?

26. Die Ärztinnen sprachen mit dem Bäcker/Jockey über die Schmerzen. Sie vermuteten, dass sein/das Becken, das ihm Probleme machte, sehr unter der täglichen Belastung bei der Arbeit gelitten hatte. 
The doctors talked to the baker/jockey about the pain. They thought that his/the pelvis, which was causing him trouble, had suffered a lot from the daily strain at work.

Hatte der Bäcker/Jockey Probleme mit seinem Becken? Y

Did the baker/jockey have trouble with his pelvis?

27. Die Krankenschwestern sorgten sich um den Arzt/Freund, der bei dem Autounfall verletzt worden war. Sie waren überzeugt, dass sein/der Arm dringend geröntgt werden müsse.

The nurses worried about the doctor/friend who had been injured in the car crash. They were sure that his/the arm needed to be x-rayed immediately.

War der Arzt/Freund bei einem Flugzeugabsturz verletzt worden?

Had the doctor/friend been injured in a plane crash?

28. Die Hausfrauen halfen dem Briefträger/Steuerberater, nach dem Unfall aufzustehen. Sie sagten, dass seine/die Brille, die zerbrochen war, wahrscheinlich repariert werden könnte.

The housewives helped the postman/tax accountant get up after the accident. They said that his/the glasses, which had broken, could probably be fixed.

War die Brille des Briefträgers/Steuerberater zerbrochen? Y

Were the postman's/tax accountant's glasses broken?

29. Die Freundinnen holten den Stadtrat/Ausländer vom Bahnhof ab. Sie fragten, ob seine/die Stadtrundfahrt interessant gewesen sei.

The friends picked up the city councilman/foreigner from the train station. They asked if his/the tour of the city had been interesting.

Holten Freundinnen den Stadtrat/Ausländer vom Flughafen ab? N

Did the friends pick up the city councilman/foreigner from the airport?

30. Die Gastgeberinnen kritisierten den Nachrichtensprecher/Geschichtsschreiber nach dem Abendessen. Sie hatten gesehen, dass sein/der Nachtisch von ihm nicht einmal probiert worden war.

The hostesses criticized the news anchor/storyteller after dinner. They had seen that his/the dessert had not even been touched.

Kritisierten die Gastgeberinnen den Nachrichtensprecher/Geschichtsschreiber? Y

Did the hostesses criticize the news anchor/story teller? 
31. Die Vermieterinnen zeigten den Bewohner/Fischer an, nachdem mehrere Mängel gefunden worden waren. Sie sagten, dass sein/der Bestechungsversuch alles nur noch schlimmer gemacht hätte.

The landladies reported the inhabitant/fisher after several defects were found. They said that his/the attempt to bribe them had only made things worse.

Nahmen die Vermieterinnen das Bestechungsgeld an? N

Did the landladies take the bribe?

32. Die Nachbarinnen machten dem Klempner/Bassisten ein Kompliment bei der Hauseinweihungsfeier. Sie fanden, dass sein/das Klettergerüst, das mitten im Garten stand, viel schöner war als ihres.

The neighbors complimented the plumber/bassist at the house warming party. They thought that his/the jungle gym, which stood in the middle of the yard, was a lot nicer than theirs.

Kritisierten die Nachbarinnen den Klempner/Bassisten? N

Did the neighbors criticize the plumber/bassist?

33. Die Sekretärinnen rieten dem Anwalt/Senator, etwas anderes anzuziehen. Sie erklärten, dass sein/der Anzug eine zu aufdringliche Farbe habe und nicht angemessen sei.

The secretaries advised the lawyer/senator to wear something else. They explained that his/the suit had a garish color and was not appropriate.

Fanden die Sekretärinnen den Anzug angemessen? N

Did the secretaries think the suit was appropriate?

34. Mehrere Besucherinnen beschwerten sich über den Priester/Herzog nach einer öffentlichen Rede. Sie fanden, das sein/das Prinzip, welches in Bezug zur Armut zum Ausdruck kam, nicht richtig war.

Several visitors complained about the priest/duke after a public speech. They thought that his/the principle he expressed regarding poverty was not right.

Beschwerten sich die Besucherinnen über den Priester/Herzog? Y

Did the visitors complain about the priest/duke?

35. Die Mädchen riefen hinter dem Bibliothekar/Fernfahrer her, der dabei war zu gehen. Sie hatten bemerkt, dass seine/die Bibel, die er immer bei sich hatte, auf einer Bank liegengeblieben war. 
The girls called after the librarian/trucker who was about to leave. They had noticed that his/the bible, which he always had with him, had been left on a bench.

Hatten die Mädchen immer eine Bibel dabei? N

Did the girls always have a bible with them?

36. Die Bankkauffrauen telefonierten mit dem Abteilungsleiter/Parteimitglied wegen der finanziellen Schwierigkeiten. Sie bedauerten, dass seine/die Absicht, den Angestellten dieses Jahr einen Bonus zu zahlen, leider unmöglich war.

The bankers talked to the manager/party member on the phone about the financial difficulties. They regretted that his/the intention to give the employees a bonus this year was unfortunately impossible.

Telefonierten die Bankkauffrauen mit dem Abteilungsleiter/Parteimitglied wegen der finanziellen Schwierigkeiten? Y

Did the bankers talk to the manager/party member on the phone about the financial difficulties?

37. Die Sekretärinnen wunderten sich über den Programmierer/Sprachforscher, der sonst immer gute Arbeit leistete. Sie hörten, dass sein/das Projekt, das er bei der Konferenz vorstellen wollte, nicht gut durchdacht sei.

The secretaries were surprised about the programmer/linguist who usually did good work. They heard that his/the project, which he wanted to present at the conference, had not been thought through very well.

Hatten die Sekretärinnen gehört, dass das Projekt besonders gut sei? N

Had the secretaries heard that the project was particularly good?

38. Die Kellnerinnen ignorierten den Anglisten/Cellisten, der häufig ins Café kam. Sie lachten über sein/das Angebot, mit ihnen nach Feierabend essen zu gehen.

The waitresses ignored the anglicist/cellist who frequently visited the cafe. They laughed about his/the offer to take them out for dinner after they finished their shift.

Kam der Anglist Cellist häufig ins Café? Y

Did the anglicist/cellist visit the cafe frequently?

39. Die Managerinnen widersprachen dem Rechenkünstler/Anlageberater während des Meetings. Sie sagten, dass seine/die Rechtfertigung des Budgets nicht schlüssig war. 
The managers disagreed with the math genius/investment consultant during the meeting. They said that his/the justification for the budget did not make sense.

Hielten die Managerinnen die Rechtfertigung des Budgets für schlüssig? N Did the managers think that the justification for the budget made sense?

40. Alle Aktivistinnen unterstützten den Produzenten/Intellektuellen aus voller Überzeugung. Sie wussten, dass seine/die Protestaktion gegen schlechte Arbeitsbedingungen in den Medien sehr wichtig war.

All the activists whole-heartedly supported the producer/intellectual. They knew that his/the protest against bad working conditions in the media was very important.

Unterstützten alle Aktivistinnen die Protestaktion? Y

Did the activists support the protest?

41. Die Investorinnen ärgerten sich sehr über den Unternehmer/Nachfolger, der einfach das Meeting verließ. Sie fanden, dass seine/die Unterbrechung der Verhandlung einen Mangel an Respekt zeigte.

The investors were very angry at the entrepreneur/successor who just left the meeting. They thought that his/the interruption of the negotiations showed a lack of respect.

Fanden die Investorinnen die Unterbrechung der Verhandlung in Ordnung? N Did the investors think the interruption of the negotiations was acceptable?

42. Die Schülerinnen kritisierten den Bauarbeiter/Landwirt, der durch die Innenstadt ging. Sie waren entsetzt, dass sein/der Bauch, der unter dem Hemd hervor quoll, ständig zu sehen war.

The students criticized the builder/farmer who was walking through town. They were shocked that his/the belly, which was bulging out from under his shirt, was constantly on display.

War der Bauch des Bauarbeiters/Landwirts ständig zu sehen? Y

Was the builder's/farmer's belly constantly on display?

43. Die Reporterinnen interviewten den Verteidiger/Innenminister nach der Urteilsverkündung. Sie hofften, dass sein/der Versuch, die Sachlage zu beschönigen, $\mathrm{zu}$ einem riesigen Medienspektakel führen würde.

The journalists interviewed the defense lawyer/Secretary of State after the sentencing. They hoped that his/the attempt to embellish the facts would cause a huge media spectacle. 
Hofften die Reporterinnen, dass es kein Medienspektakel geben würde? N Did the journalists hope that there would be no media spectacle?

44. Die Hausfrauen grüßten den Fotografen/Gesandten, der in der Wohnung im Erdgeschoss wohnte. Sie erklärten, dass seine/die Formalität, die er ihnen gegenüber zeigte, völlig unnötig sei.

The housewives greeted the photographer/ambassador, who lived in the apartment on the first floor. They explained that his/the formality he displayed towards them was completely unnecessary.

Sagten die Hausfrauen, dass die Formalität, die der Fotograf/Gesandte ihnen gegenüber zeigte, unnötig sei? Y

Did the housewives say that the formality the photographer/ambassador was displaying towards them was unnecessary?

45. Die Wählerinnen zwangen den Kommunisten/Politiker, der zum Minister ernannt worden war, zurückzutreten. Sie meinten, dass sein/der Kommentar zur Frauenquote zu sexistisch gewesen sei.

The voters forced the communist/politician, who had been appointed minister, to resign. They thought that his/the comment about the women's quota had been too sexist.

Stimmten die Frauen dem Kommunisten/Politker in Bezug auf die Frauenquote $\mathrm{zu}$ ? N

Did the women agree with the communist/politician regarding the women's quota?

46. Die Sekretärinnen beruhigten den Uhrmacher/Veteranen am Telefon. Sie versprachen, dass seine/die Urkunde sogleich abgeschickt werden würde und bald bei ihm ankommen würde.

The secretaries calmed down the watchmaker/veteran on the phone. They promised that his/the certificate would be mailed immediately and would arrive soon.

War die Urkunde schon abgeschickt worden? N

Had the certificate been mailed already?

47. Die Verkäuferinnen berieten den Kassierer/Methodisten beim Kauf einer neuen Stereoanlage. Sie warnten, dass seine/die Kassette, die ihm so wichtig war, auf einem CD-Spieler nicht abgespielt werden könne. 
The sales assistants advised the cashier/Methodist regarding the purchase of a new stereo set. They warned that his/the cassette, which was so important to him, could not be played on a CD player.

Sagten die Verkäuferinnen, dass die Kassette auf einem CD-Spieler abgespielt werden könne? N

Did the sales assistants say that the cassette could be played on a CD player?

48. Die Mitbewohnerinnen begannen, sich über den Frisör/Barmann zu ärgern, der erst vor kurzem eingezogen war. Sie fanden, dass seine/die Fritteuse in der Küche zu viel Platz einnahm.

The housemates were beginning to be annoyed with the hairdresser/bartender who had only moved in recently. They thought that his/the deep-fat fryer was taking up too much space in the kitchen.

Dachten die Mitbewohnerinnen, dass die Fritteuse zu viel Platz einnahm? Y Did the housemates think that the deep-fat fryer was taking up too much space?

49. Die Juristinnen verhörten den Jäger/Häftling während der Verhandlung. Sie wussten, dass sein/der Jähzorn, für den er bekannt war, wahrscheinlich zu dem verantwortungslosen Verhalten geführt hatte.

The lawyers cross-examined the hunter/prisoner during the trial. They knew that his/the bad temper, which he was famous for, had probably caused his reckless behavior.

War der Jäger/Häftling für ein ausgeglichenes Temperament bekannt? N

Was the hunter/prisoner known for having an even temper?

50. Die Krankenschwestern beruhigten den Taucher/Pächter nach der Visite. Sie sagten, dass seine/die Tauglichkeit für seinen Beruf durch die Operation nicht beeinträchtigt werden würde.

The nurses calmed down the diver/tenant after the medical round. They said that his/the capability for doing his job would not be affected by the surgery.

Beruhigten die Krankenschwestern den Taucher/Pächter? Y

Did the nurses calm down the diver/tenant?

51. Die Sekretärinnen unterhielten sich mit dem Akademiker/Bauherrn an der Rezeption. Sie sahen, dass seine/die Aktentasche, die er unter dem Arm trug, offen war und hofften, dass nichts herausfallen würde. 
The secretaries talked to the academic/contractor at the reception. They saw that his/the briefcase, which he was carrying under his arm, was open and hoped that nothing would fall out.

Unterhielten sich die Sekretärinnen mit dem Akademiker/Bauherrn am Telefon? $\mathrm{N}$

Did the secretaries talk to the academic/contractor on the phone?

52. Die Studentinnen trafen den Architekten/Historiker im Büro. Sie fragten, ob sein/das Archiv, auf das nur er Zugriff hatte, möglicherweise hilfreiche Dokumente für ihr Projekt beinhaltete.

The students met the architect/historian at the office. They asked if his/the archive, which only he had access to, might potentially include helpful documents for their project.

Hatte nur der Architekt/Historiker Zugriff auf das Archiv? Y

Did only the architect/historian have access to the archive?

53. Mehrere Journalistinnen interviewten den Richter/Kanzler nach der Pressekonferenz. Sie fragten, ob sein/der Ring an der linken Hand irgendeine wichtige Bedeutung habe.

Several journalists interviewed the judge/chancellor after the press conference. They asked if his/the ring on his left hand had any significant meaning.

Fragten die Journalistinnen, ob die Kette irgendeine wichtige Bedeutung habe? N Did the journalists ask if the necklace had any significant meaning?

54. Die Stewardessen lächelten den Reiter/Sportler an, der ins Flugzeug einstieg. Sie fragten, ob seine/die Reise zu der Veranstaltung angenehm gewesen sei.

The stewardesses smiled at the rider/athlete, who was boarding the plane. They asked if his/the journey to the meetings had been pleasant.

Stieg der Reiter/Sportler ins Flugzeug ein, als die Stewardessen ihn anlächelten? Y

Was the rider/athlete boarding the plane when the stewardesses smiled at him?

55. Die Filmstudentinnen befragten den Regisseur/Experten zu dem Film. Sie fanden, dass seine/die Reaktion auf das Ende zu emotional gewesen sei. The film students interviewed the director/expert about the movie. They thought that his/the reaction to the end had been too emotional. 
Dachten die Studentinnen, dass die Reaktion des Regisseurs/Experten auf das Ende angemessen gewesen sei? $\mathrm{N}$

Did the students think that the director's/expert's reaction to the end had been appropriate?

56. Die Personalmanagerinnen kritisierten den Statisten/Ökonom, der Probleme hatte, Anweisungen zu folgen. Sie sagten, dass sein/der Starrsinn, den er von Anfang an gezeigt hatte, seiner weiteren Karriere sehr im Weg stehen würde.

The human resources mangers criticized the extraleconomist who had trouble following directions. They said that his/the stubbornness, which he had shown right from the start, would get in the way of his career.

Kritisierten die Personalmanagerinnen den Statisten/Ökonom? Y

Did the human resources managers criticize the statistician/economist?

57. Die Empfangsdamen gaben sich Mühe, den Komponisten/Besitzer beim Theaterbesuch zufriedenzustellen. Sie gingen sicher, dass sein/der Kollege, auf den er wartete, einen guten Platz bekam.

The receptionists tried very hard to make the composer/owner happy during the theater visit. They made sure that his/the colleague who he was waiting for got a good seat.

War es den Empfangsdamen egal, ob der Komponist/Besitzer zufrieden war? N Did the receptionists not care if the composer/owner was happy?

58. Die Putzfrauen suchten den Matrosen/Raucher auf dem ganzen Deck. Sie fanden, dass seine/die Matratze gewendet werden müsse und brauchten dafür seine Hilfe.

The cleaning ladies searched the whole deck for the sailor/smoker. They thought that his/the mattress had to be turned over and needed his help for that.

Brauchten die Putzfrauen Hilfe, um die Matratze zu wenden? Y

Did the cleaning ladies need help to turn over the mattress?

59. Die Verwalterinnen beschwerten sich beim Inhaber/Helfer am Ende des Monats. Sie sagten, dass seine/die Investition in das Projekt nicht groß genug gewesen sei. The administrators complained to the owner/helper at the end of the month. They said that his/the investment in the project had not been enough.

Fanden die Verwalterinnen, dass die Investition groß genug gewesen war? N Did the administrators think that the investment had been enough? 
60. Die Beraterinnen riefen den Rentner/Gelehrten nachmittags zu Hause an. Sie versprachen, dass seine/die Rendite dieses Jahr besonders gut sein würde.

The advisers called the pensioner/scholar at home in the afternoon. They promised that his/the financial return would be particularly good this year.

Versprachen die Beraterinnen, dass die Rendite dieses Jahr besonders gut sein würde? Y

Did the advisers promise that the return would be particularly good this year?

61. Die Sekretärinnen rieten dem Vermieter/Chauffeur, die Bank zu kontaktieren. Sie bestätigten, dass seine/die Versicherung den Schaden übernehmen würde.

The secretaries advised the landlord/chauffeur to contact the bank. They confirmed that his/the insurance would cover the damage.

Rieten die Beraterinnen dem Vermieter/Chauffeur, den Schaden selbst zu bezahlen? $\mathrm{N}$

Did the advisers advise the landlord/chauffeur to pay for the damage himself?

62. Die Buchhalterinnen bemitleideten den Redakteur/Manager, der bei dem Sturm rausgehen musste. Sie hofften, dass sein/der Regenschirm nicht kaputt gehen würde.

The bookkeepers felt sorry for the editor/manager, who had to go outside in the storm. They hoped that his/the umbrella would not break.

Bemitleideten die Buchhalterinnen den Redakteur/Manager? Y

Did the bookkeepers feel sorry for the editor/manager?

63. Die Soldatinnen wunderten sich über den Trommler/Söldner, der ein nasses Hemd trug. Sie wussten nicht, dass sein/der Trockner, den er erst vor kurzem gekauft hatte, schon kaputt war.

The soldiers were surprised about the drummer/mercenary, who was wearing a wet shirt. They didn't know that his/the dryer, which he had bought only recently, was already broken.

Trug der Trommler/Söldner ein trockenes Hemd? N

Was the drummer/mercenary wearing a dry shirt?

64. Die Ärztinnen rieten dem Karikaturenzeichner/ Langstreckenläufer, eine Auszeit zu nehmen. Sie erklärten, dass sein/das Kardiogramm, das endlich ausgewertet worden war, ihnen Sorgen machte. 
The doctors advised the cartoonist/long-distance runner to take some time off. They explained that his/the cardiogram, which had finally been analyzed, looked concerning.

Machte den Ärztinnen das Kardiogramm Sorgen? Y

Were the doctors worried about the cardiogram?

\section{Fillers}

1. Die Bibliothekarin sagte, dass Mia alle Bücher noch an diesem Nachmittag ins Regal zurückstellen müsste. Sie hatte aber nur Zeit, einige der Bücher zurückzustellen, bevor sie nach Hause gehen musste.

Sollte die Bibliothekarin die Bücher zurück ins Regal stellen? N

2. Die Schüler sollten alle Artikel lesen, bevor sie die Fragen beantworteten. Es war offensichtlich, dass Anne nur ein paar der Artikel gelesen hatte, da ihre Antworten keinen Sinn ergaben.

Sollten die Schüler zur Vorbereitung Artikel lesen? Y

3. Der Bauarbeiter versprach alle Renovierungsarbeiten bis zum Ende des Sommers fertig gestellt zu haben. Ende Juli hatte er aber nur einige beendet, da das Wetter häufig sehr schlecht gewesen war.

Verzögerten Probleme mit dem Budget die Renovierungsarbeiten? N

4. Die Grundschullehrerin hoffte, dass die Kinder in der Klasse artig sein würden. Sie war entsetzt, als sie merkte, dass nur einige von ihnen ihren Anweisungen folgten.

Erwartete die Lehrerin, dass die Kinder sich gut benahmen? Y

5. Der Kurator hoffte, dass alle Bilder sich für viel Geld verkaufen lassen würden. Er war enttäuscht zu hören, dass nur ein paar von ihnen wertvoll waren.

Erwartete der Kurator, dass die Bilder wertvoll waren? Y

6. Der Koch wollte alle Gäste des Restaurants mit dem Essen begeistern. Er wusste aus Erfahrung, dass nur einige von ihnen die Raffinesse der Speisen zu schätzen wissen würden.

War es dem Koch wichtig, dass die Gäste zufrieden waren? Y

7. Auf dem Ausflug in den Zoo war Susi entschlossen, viele Tiere mit ihrem mitgebrachten Essen zu füttern. Der Zoowärter erinnerte sie daran, dass man nur einige von ihnen von Hand füttern konnte.

Wollte Susi die Tiere im Zoo füttern? Y 
8. Der Zahnarzt hoffte, dass die Patienten sich während der Zahnreinigung wohl fühlten. Er hatte sich damit abgefunden, dass nur einige von ihnen ihren Besuch genießen würden.

Erwartete der Zahnarzt, dass alle Patienten gerne zur Zahnreinigung kamen? N

9. Der Bürgermeister hoffte, dass alle Mitglieder seines Kabinetts ehrenhaft und vertrauenswürdig waren. Dennoch sprach er nur mit einigen von ihnen über die heikelsten Angelegenheiten.

Besprach der Bürgermeister alle Angelegenheiten mit seinem gesamten Kabinett? $\mathrm{N}$

10. Die Ballerina versprach das meiste der Choreographie für das neue Stück auswendig zu lernen. Aber ihr Tanzpartner hatte nur einen Teil davon rechtzeitig zur ersten Probe gemeistert.

War es die Ballerina, die nicht auf die Probe vorbereitet war? N

11. Die Babysitterin hasste es, viele gute Fernsehsendungen zu verpassen, wenn die Kinder zu lange aufblieben. Sie war froh, dass sie heute Abend nur ein paar davon verpasst hatte, da sie sich gut benommen hatten.

Waren es die Kinder, die die Fernsehsendungen nicht verpassen wollten? N

12. Emma musste die Hausaufgaben fertig machen, bevor sie mit ihren Freunden ausgehen konnte. Um 9 Uhr hatte sie nur einen Teil davon geschafft, aber sie ging trotzdem etwas trinken.

Blieb Emma zu Hause, um ihre Hausaufgaben zu machen? N

13. Die Frisörin wollte, dass alle Kunden sich schön fühlten, wenn sie den Salon verließen. Es betrübte sie zu hören, dass nur einige von ihnen ihre kreativen Haarschnitte schätzten.

Wollte die Frisörin, dass ihre Kunden zufrieden waren? Y

14. Die Yogalehrerin erwartete, dass alle Kursteilnehmer ihre eigene Matte mitbringen würden. Heute Morgen war sie verärgert, dass nur einige von ihnen gut vorbereitet zum Unterricht erschienen.

Sollten die Kursteilnehmer ihre eigenen Matten mitbringen? Y

15. Der Schriftsteller hoffte, dass viele Buchhandlungen sein neues Buch gut sichtbar auslegen würden. Sein Manager teilte ihm mit, dass nur einige von ihnen das Buch offensiv vermarkten würden.

Hatte der Schriftsteller ein neues Buch veröffentlicht? Y 
16. Der Politiker versprach, dass die Wähler noch dieses Jahr Verbesserungen bemerken würden. Es war deprimierend zu wissen, dass nur einige von ihnen ihm glaubten.

War es der Politiker, der Verbesserungen versprach? Y

17. Der Ernährungswissenschaftler wollte, dass alle Produkte bei McDonalds mit Warnhinweisen gekennzeichnet würden. Der Sprecher der Fast-Food-Konzerne beharrte darauf, dass nur einige davon einen hohen Fettgehalt hatten.

Dachte der Ernährungswissenschaftler, dass McDonalds-Produkte ungesund seien? Y

18. Der Lehrer hoffte, dass die Schüler in seiner Klasse die meisten Aufgaben schnell lösen könnten. Die Schüler beschwerten sich, dass nur einige davon ohne Taschenrechner gelöst werden könnten.

Wollte der Lehrer, dass die Schüler für die Aufgaben lange brauchten? N

19. Die Fans hofften, dass die Fußballmannschaft in dieser Saison viele Heimspiele gewinnen würde. Am Ende schafften sie es wegen einer Reihe von Verletzungen aber nur einige davon zu gewinnen.

War es die Schuld des Trainers, dass die Fußballmannschaft so häufig verlor? N

20. Julia versicherte ihren Freunden, dass die Hellseher, die sie gesehen hatte, definitiv Schwindler waren. Vanessa erinnerte sie daran, dass nur einige von ihnen ihr schlechte Ratschläge gegeben hatten.

Vertraute Julia allen Hellsehern? N

21. Die Fußballer sollten alle Übungen vor Ende des Trainings schaffen. Der Torwart dachte, dass nur einige davon für die Mannschaft notwendig waren.

Sollten die Fußballer während des Trainings bestimmte Übungen machen? Y

22. Die neuen Cheerleaderinnen mussten die Fangesänge für das American-Football Spiel heute Abend kennen. Melissa hatte nur Zeit, einige davon zu üben, bevor sie auf das Spielfeld musste.

War es ein Basketball-Spiel, auf das sich die Cheerleaderinnen vorbereiteten? N

23. Der Veranstalter sagte, dass die Band viele neue Songs auf ihrer Europa-Tournee spielen sollte. Ihr Manager riet ihnen aber nur einige davon zu spielen, da die Fans die alten Alben mochten.

War die Band auf Europa-Tournee? Y 
24. Lina hoffte, dass die Mädchen in ihrer neuen Volleyball-Mannschaft gute Sportlerinnen sein würden. Beim ersten Training sah sie, dass nur einige von ihnen wussten, wie man einen Ball wirft.

Hoffte Lina, dass die Mädchen in der Volleyball-Mannschaft freundlich sein würden? N

25. Ben wurde bei einem Autounfall schwer verletzt. Die Krankenschwester sagte, dass er im Krankenhaus bleiben müsse, bis seine gebrochenen Rippen geheilt seien.

War Ben im Krankenhaus, um seinen Blinddarm entfernen zu lassen? N

26. John verbrachte letzten Freitag in einer Bar, wo er einen Wodka nach dem anderen trank. Die Kellnerin fand, dass er nicht so viel hochprozentigen Alkohol trinken sollte.

Hat John sich letzten Freitag betrunken? Y

27. Paul ging in den Supermarkt, um importierten Käse zu kaufen. Der Kassierer sagte, dass er dafür in den Gourmetladen am anderen Ende der Stadt gehen müsse.

Verkaufte der Supermarkt importierten Käse? N

28. James stand während der Landung des Flugzeugs auf, um aus dem Fenster sehen zu können. Die Stewardess sagte, dass er wegen all der Turbulenzen sitzen bleiben müsse.

Stand James auf, weil seine Beine eingeschlafen waren? N

29. Der Paartherapeut arbeitete mit einem unzufriedenen Paar, das sich ständig stritt. Die Ehefrau hoffte, dass er sich unvoreingenommen ihre Probleme anhören würde.

Arbeitete der Paartherapeut mit einem glücklichen Paar? N

30. Der Hochzeitsfotograf hatte viel Erfahrung mit unattraktiven Auftraggebern. Die Braut hoffte, dass er in der Lage sein würde, das Paar in den Fotos gut aussehen zu lassen.

Wollte die Braut auf den Fotos gut aussehen? Y

31. Leon buchte ein Zimmer in einem Strandhotel. Die Rezeptionistin sagte, dass das Zimmer mit Meerblick einen Aufpreis kosten würde.

Kostete das Zimmer mit Meerblick extra? Y

32. Luca beichtete, dass er etwas in einem Süßwarenladen geklaut hatte. Der Pfarrer versicherte, dass ihm für so ein kleines Delikt vergeben werden würde. 
Hatte Luca etwas in einem Süßwarenladen geklaut? Y

33. Noah brachte ein zerrissenes Hemd in eine nahegelegene Schneiderei. Die Schneiderin versprach, dass er das geflickte Hemd spätestens am Freitag abholen könnte.

Brachte Noah eine Hose zur Schneiderin? N

34. Tim war der Manager eines Chors. Der Sopran hoffte, dass er interessante Auftritte für die Gruppe organisieren würde.

Wollte der Sopran, dass Tim Auftritte für den Chor organisierte? Y

35. Jonas sitzt gerne auf der Veranda und unterhält sich mit den älteren Nachbarn. Die alte Dame von gegenüber findet, dass er lieber mit anderen Kindern spielen sollte.

Hat Jonas ältere Nachbarn? Y

36. Der Beerdigungsunternehmer unterhielt sich mit der Familie des Verstorbenen. Die Witwe erwartete, dass er den Leichnam so präparierte, dass er bei der Trauerfeier wie lebendig aussah.

Hinterließ der Verstorbene eine Witwe? Y

37. Peter arbeitete als Assistent an einem Film-Set in Hollywood. Die Hauptdarstellerin verlangte, dass er jeden Morgen Kaffee für alle mitbringen sollte.

Arbeitete Peter an einem Film-Set? Y

38. Felix war sehr verärgert, als ein Spieler seiner Fußballmannschaft eine rote Karte bekam. Der Platzanweiser sagte, dass er sich beruhigen müsse, um nicht aus dem Stadion verwiesen zu werden.

War es Felix egal, dass ein Spieler eine rote Karte bekam? N

39. Elias bekam einen Strafzettel, weil er vor einem Hydranten geparkt hatte. Der Polizist erklärte, dass er in dem nahegelegenen Parkhaus hätte parken sollen.

Bekam Elias einen Strafzettel, weil er zu schnell gefahren war? N

40. Der neue Hausmeister verlief sich häufig in dem großen Fabrikgebäude. Der Nachtwärter sagte, dass er in ein paar Wochen alle wichtige Räume finden können würde.

Arbeitete der Hausmeister in einem großen Hotel? N 
41. Der Hotelgast rief an der Rezeption an, als die Toilette begann überzulaufen. Die Rezeptionistin versprach, dass er innerhalb von zwei Stunden wieder eine funktionierende Toilette haben würde.

Hatte der Hotelgast ein Problem mit der Toilette? Y

42. Joseph hatte einen Streit begonnen, der sich zu einer Schlägerei auf dem gesamten Schulhof ausweitete. Die Direktorin verlangte, dass er sich bei den unbeteiligten Schülern, die verletzt worden waren, entschuldigte.

Hatte Joseph einen Streit begonnen? Y

43. Robert begann gestern eine Essensschlacht in der Schulkantine und wurde erwischt. Die Pausenaufsicht verkündete, dass er alles alleine saubermachen müsste, damit er seine Lektion lernte.

Musste Robert alleine saubermachen? Y

44. Der Redenschreiber des Kanzlers wurde am Montag wegen eines dringenden Auftrags angerufen. Die Sekretärin erklärte, dass er eine Pressemitteilung schreiben müsste, die am Freitag veröffentlicht werden sollte.

Sollte die Pressemitteilung am Dienstag veröffentlicht werden? N

45. Stephan beschloss seine Haare lila zu färben. Die Frisörin versprach, dass er seine außergewöhnliche Wahl nicht bereuen würde.

Wollte Stephan seine Haare schwarz färben? N

46. Der Bräutigam hatte eine Panikattacke in der Limousine auf dem Weg zur Hochzeit. Der Trauzeuge hoffte, dass er sich bis zur Zeremonie wieder beruhigen würde.

War der Bräutigam vor der Hochzeit entspannt? N

47. David trat dem Schulorchester bei, obwohl er nicht besonders gut war. Der Flötist versprach, dass er mit ein bisschen Übung bald auch die schwierigeren Stücke spielen können würde.

Trat David dem Schulorchester bei? Y

48. Der Tierarzt fuhr zu einem abgelegenen Bauernhof, um eine kranke Kuh zu untersuchen. Der Bauer hoffte, dass er herausfinden könnte, warum die Kuh keine Milch mehr gab.

Besuchte der Tierarzt ein krankes Tier? Y

49. Klaus musste alle Prüfungen bestehen, um seinen Schulabschluss zu schaffen. Er bestand die Prüfungen in Mathe und Chemie ohne Probleme, aber die anderen waren viel zu schwierig. 
Bestand Klaus die Prüfung in Biologie? N

50. Sebastian wollte alle Gänge fertig haben, bevor die Gäste zum Abendessen eintrafen. Am späten Nachmittag hatte er den Hauptgang gekocht, aber er hatte noch nicht einmal angefangen, die Vorspeise oder den Nachtisch vorzubereiten. Hatte Sebastian den Hauptgang rechtzeitig vorbereitet? Y

51. Tara hatte vorgehabt, alle Kapitel für das Seminar am Freitag zu lesen. Am Donnerstagabend las sie zwei davon, bevor sie ins Bett ging, aber die anderen waren viel zu lang.

Hatte Tara vorgehabt die Kapitel für das Seminar nicht zu lesen? N

52. Hanna beschloss, alle Mahlzeiten zu Hause zu kochen, um nicht zuzunehmen. Während ihrer Prüfungen kochte sie ein paar mit gesunden Zutaten, aber ansonsten aß sie nur Fertiggerichte.

Wollte Hanna vermeiden zuzunehmen? Y

53. Max sagte, er würde die Klassenzimmer für die Schulfeier dekorieren. Heute nach Schulschluss dekorierte er einige mit bunten Luftschlangen, aber für die anderen blieb keine Zeit mehr.

Dekorierte Max die Aula? N

54. Julian hoffte, alle Preise bei dem Wissenschaftswettbewerb zu gewinnen. Wie erwartet, gewann er einen für sein neues Experiment, aber andere Schüler gewannen auch welche.

Gewann Julian alle Preise? N

55. Nicole sollte ihr Gemüse aufessen, bevor sie den Nachtisch essen durfte. Gestern beim Abendessen aß sie ein bisschen Gemüse, ohne sich zu sträuben, aber das meiste blieb auf ihrem Teller liegen.

Sollte Nicole ihr Gemüse essen? Y

56. Laura wollte alle Hauptstädte Europas sehen, bevor sie mit der Uni anfing. Über den Sommer fuhr sie mit dem Zug in einige nahegelegenen, aber die anderen waren $\mathrm{zu}$ weit weg.

Hatte Laura vor alle Hauptstädte Europas zu sehen? Y

57. Finn wollte alle Seminare, die von der Physikfakultät angeboten wurden, belegen. In seinem letzten Semester belegt er einige davon und bekam gute Noten, aber die anderen waren für ihn viel zu schwierig.

Wollte Finn alle Seminare in Biologie belegen? N 
58. Der Gärtner beschloss, Eichen an der Nordseite des Hauses zu pflanzen. Gestern Morgen pflanzte er dort einige und danach wollte er auch welche an der Südseite pflanzen.

Pflanzte der Gärtner Rosen? N

59. Die Lehrerin hatte vor, alle zehn Aufsätze zu benoten, bevor ihre Lieblingssendung anfing. Nach dem Abendessen benotete sie ohne Probleme sechs davon, aber der Rest musste bis später warten.

Hatte die Lehrerin vor die Aufsätze zu benoten? Y

60. Karl wollte in sieben Restaurants in seinem Viertel essen, bevor der Sommer vorbei war. Während des ersten Monats aß er in drei Restaurants ohne zuzunehmen, aber alle anderen servierten sehr fettiges Essen.

Wollte Karl in allen Restaurants der Stadt essen? N

61. Tobias wollte sehen, wie sich in den Parks in seiner Umgebung das Laub im Herbst verfärbte. Im Frühherbst besuchte er einige der Parks, als die Blätter gelb waren, und entschied sich, in die anderen Parks erst im November zu gehen, wenn die Farben interessanter sein würden.

Wollte Tobias sehen, wie sich das Laub verfärbte? Y

62. Der Filmfanatiker wollte während des Schneesturms einige Charlie Chaplin Film sehen. Am ersten Tag guckte er sich einige mit seinen Freunden an, aber der Rest war online nicht verfügbar.

Wollte der Filmfanatiker alle Fred Astair Filme sehen? N

63. Johann hoffte, alle Spieler seiner Lieblingsmannschaft zu treffen. Vor dem Spiel traf er fünf und bekam ihre Autogramme, und auf den Rest wollte er nach dem Spiel warten.

Wollte Johann die Spieler seiner Lieblingsmannschaft treffen? Y

64. Katrin beschloss, sich drei Universitäten anzugucken, bevor sie entschied, wo sie sich bewerben wollte. In ihrem letzten Schuljahr besuchte sie zwei zum Tag der offenen Tür, aber die andere war zu weit weg.

Besuchte Katrin alle drei Universitäten, bevor sie sich bewarb? N

65. Der Postbote sollte alle Pakete in der gefährlichen Gegend zustellen. Obwohl er Angst hatte, lieferte er einige aus, bevor es zu dunkel wurde, aber der Rest wurde aus seinem Lieferwagen gestohlen.

Hatte der Postbote Angst? Y 
66. Der Filmkritiker sollte alle Filme, die diese Woche herauskamen, besprechen. In der Zeitung vom Freitag besprach er einige, die er sehr gut fand, alle anderen waren furchtbar gewesen.

Besprach der Filmkritiker Filme, die erst in ein paar Wochen herauskamen? N

67. Der Manager der Band wollte alle ihre Konzerte an der Ostküste sehen. Am Anfang sah er einige in New Jersey und New York, aber der Rest der Tour wurde abgesagt.

Wurden einige der Konzerte abgesagt? Y

68. Lea wollte am Tag vor Weihnachten in einige Läden gehen. Früh am Morgen ging sie in ein paar Läden, bevor die Schlangen zu lang wurden, aber die anderen Läden waren viel zu voll.

War es der Tag nach Weihnachten, an dem Lea einkaufen gehen wollte? N

69. Melanie wollte sieben Bücher lesen, die ihre ältere Schwester für die Schule lesen musste. Obwohl sie jünger war, las sie vier davon ohne Hilfe, aber die anderen waren über ihrem Niveau.

Las Melanie Bücher, die eigentlich ihre große Schwester lesen sollte? Y

70. Lars musste seine Kollegen überzeugen, Geld für die Spendenaktion, die von seiner Frau organisiert wurde, zu spenden. In der Mittagspause überredete er drei ihm diesen Gefallen zu tun, aber die anderen hatten kein Geld dabei.

Wurde die Spendenaktion von Lars organisiert? N

71. Der Sänger wollte nur traditionelle Lieder für sein neues Weihnachtsalbum aufnehmen. Auf Anraten seines Managers nahm er aber auch Lieder auf, die er selber geschrieben hatte.

Waren alle Lieder auf dem Weihnachtsalbum von dem Sänger selbst geschrieben worden? N

72. Der Politiker war gegen die neuen Steuergesetze, die gerade debattiert wurden. Nach einer langen Diskussion stimmte er trotzdem dafür, weil seine Partei ihn unter Druck gesetzt hatte.

Hatte seine Partei den Politiker unter Druck gesetzt? Y

\section{Experiment 2: English}

The experiment contained 64 item sets of 8 conditions. Comprehension questions are only included in the phonological conditions when they differed from the questions used in the semantic conditions. 


\section{Semantic conditions}

1. Several publishers approached the journalist/congressman who had recently made headlines. They said that his/the article which had been recently published had stirred up public opinion.

Did the journalist/congressman recently make headlines? Y

2. The maids lectured the carpenter/journalist for being terribly messy. They stared at his/the overalls, which were stained and caked with mud.

Was the carpet muddy? Y

3. The military prosecutors questioned the therapist/civilian during the trial. They focused on his/the notes, which documented a soldier's misconduct.

Did the prosecutors question the therapist/civilian before the trial? $\mathrm{N}$

4. Many people envied the photographer/therapist from the first floor. They knew that his/the studio was very large and had lots of windows.

Did the photographer/therapist live on the first floor? Y

5. Some housewives visited the minister/hunter, who had missed Bible studies. They commented that his/the congregation had been concerned about his failing health.

Was the minister/hunter present in Bible studies? N

6. The townspeople mourned the reverend/cowboy who had died recently. They laid out his/the Bible in the coffin with him, as he had requested.

Did the townspeople mourn the reverend/cowboy? Y

7. Several colleagues criticized the manager/player for the failed ad campaign. They worried that his/the company was losing value in the stock market.

Were the colleagues confident in the company's market value? $\mathrm{N}$

8. The receptionists chatted with the attorney/manager in the office. They asked about his/the lawsuit against the music industry.

Did the receptionists ask about the lawsuit? Y

9. The CIA agents scrutinized the chairman/terrorist for the suspicious transactions. They feared that his/the committee was merely a front for a more nefarious plot.

Did the CIA think that the charity was real? $\mathrm{N}$ 
10. The TV producers insulted the reporter/champion who had become famous during the Olympics. They knew that his/the interview would be long and tedious.

Did the TV producers think the interview would be short? $\mathrm{N}$

11. The actresses criticized the chauffeur/bodyguard for having a bad attitude. They got into his/the car and complained the entire ride home.

Did the chauffeur/bodyguard have a good attitude? $\mathrm{N}$

12. The agents arrested the sheriff/killer after searching the house. They claimed that his/the badge on the desk connected him to the victim.

Did the agents suspect the sheriff/killer in the recent murder? Y

13. The hostage negotiators freed the captain/doctor with clever trickery. They switched out his/the uniform from the prison with a lab coat.

Did the hostage negotiators free the captain/doctor? Y

14. Some robbers attacked a knight/priest who was traveling to Avignon. They struck his/the sword out of the palm of his hand and demanded all his money.

Did the robbers demand all the money? Y

15. The directors relocated the officer/agent after the war. They thought that his/the station in Iraq would no longer be necessary.

Did the directors leave the officer/agent in his location? $\mathrm{N}$

16. The plaintiffs argued with the judge/lawyer after the trial. They thought that his/the verdict couldn't have been arrived at fairly.

17. Many critics admired the producer/graduate from the acclaimed art school. They referred to his/the film, which had won many awards.

Was the producer/graduate from an acclaimed art school? Y

18. The rebels deposed the general/president who had recently risen to power. They threw back his/the army in a series of decisive and bloody battles.

Was the army thrown back in only one battle? $\mathrm{N}$

19. The doormen let the student/gentleman into the apartment complex. They searched through his/the backpack to make sure he wasn't carrying anything dangerous.

Did the doormen let the gentleman/student in? Y

20. The donors watched the gentleman/student at the ticket booth. They suspected that his/the monocle was all for show. 
Were the donors suspicious of the monocle? Y

21. The doctors told the painter/teenager to prepare for the worst after the operation. They hoped his/the pictures from the trip he had taken with friends would cheer him up.

Did the doctors tell the painter/teenager to prepare for the best? $\mathrm{N}$

22. The students disliked the intern/advisor who took notes in every meeting. They complained about his/the typing because the keyboard on his laptop was very loud.

Did the intern/advisor take notes in every meeting? Y

23. The neighbors knew the gardener/playboy was a little eccentric. When they found his/the flowers in the middle of the street, however, they felt he had gone too far.

Was the garbage in the middle of the street? Y

24. The girls met a(n) member/artist of(from) the local performing arts center. They asked whether his/the dues were terribly exorbitant.

Was the member/artist from a faraway performing arts center? $\mathrm{N}$

25. The managers scolded the bellboy/rocker for eating too much. They pointed to his/the foodcart, which he had nearly emptied.

Did the managers scold the bellboy/rocker? Y

26. The visitors congratulated the cook/prince on the renovations recently made to the palace. That thought that his/the kitchen had turned out particularly lovely.

Did the cook/prince make amateur artwork? Y

27. The women helped the grandpa/senator get ready for the reunion. They picked up his/the bifocals from the floor, where he had dropped them last night.

Were the bifocals on the couch? N

28. The security agents searched the warden/psycho at the political rally. They took away his/the baton so that he couldn't hurt anyone with it.

Did the security agents ignore the warden/psycho? $\mathrm{N}$

29. Many friends helped the wrestler/realtor at the scene of the car accident. They asked about his/the trainer, who had also been in the car.

Was the trainer also in the car? Y

30. The detectives asked the deputy/singer permission to search the house. They found his/the gun beneath the bed, which he did not have a license for. 
Did the detectives ask for the deputy's/singer's permission? Y

31. The maintenance men told the singer/deputy about a problem. They had broken his/the piano and would have to repair that first.

Did the maintenance men say there was no problem? $\mathrm{N}$

32. Some wolves had been troubling a shepherd/resident at the farm. They had attacked his/the goats and even killed one just last week.

Did the wolves leave the goats alone? $\mathrm{N}$

33. Many coworkers told the policeman/engineer to eat more healthily. They exclaimed that his/the doughnuts alone were expanding his waistline by an inch a year.

Did the coworkers think the donuts were healthy? $\mathrm{N}$

34. The ladies calmed down the waiter/baron who had tripped into the dining room. They picked up his/the tray full of dropped wine glasses and asked him if he was okay.

Did the waiter/baron drop a tray of wine glasses? Y

35. The military tribunal punished the admiral/surgeon after the war. They stripped his/the post away from him and sent him back to civilian life.

Did the military tribunal send the admiral/surgeon back to civilian life? Y

36. The trainers evaluated the swimmer/recruit after a hard day's work. They said that his/the goggles would need to be replaced.

Did the trainers say that the goggles were fine? $\mathrm{N}$

37. The secretaries complained about the commander/director who sent unintelligible memos. They couldn't understand his/the military jargon and often disregarded his orders entirely.

Were the commander's director's messages easy to read? $\mathrm{N}$

38. The players brought the coach/driver back the missing belongings. They had found his/the whistle on one of the bus seats along with a pair of sunglasses.

Did the players find a pair of sunglasses? Y

39. The royal family praised the emperor/citizen responsible for the recent policy changes. They said that his/the kingdom had really prospered as a direct result.

Did the emperor/citizen make recent policy changes? Y

40. The clerks saw the executive/salesman hurry into the meeting late. They stared at his/the Porsche longingly after he parked it right out front. 
Was the executive/salesman on time to the meeting? $\mathrm{N}$

41. The police questioned the professor/boyfriend of the recently murdered girl. They were shocked by his/the eloquence when they finally convinced him to talk. Was a girl recently murdered? Y

42. The reporters kicked the criminal/genius out of the office after the interview. They refused to listen to his/the scheme to take over the media.

Did the reporters keep the criminal/genius in the room after the interview? $\mathrm{N}$

43. The colleagues asked the boxer/critic to tidy up the shared workspace. They complained that his/the gloves stank and needed to be taken home.

Were the gloves kept at home? $\mathrm{N}$

44. The party guests avoided the acrobat/sheikh from the foreign country. They sneered at his/the tumbling across the room and found him altogether ridiculous.

Did the party guests enjoy the tumbling? N

45. The assistants helped the actor/pilot get ready. They worried that his/the costume would no longer fit.

Did the assistants help the actor/pilot? Y

46. The diplomats asked the ambassador/emperor to speak more plainly. They said that his/the negotiations couldn't proceed without clarification.

Did the diplomats want plainer negotiations? Y

47. The city council chastised the architect/amateur for threatening public safety. They worried that his/the construction project wasn't adhering to proper building code.

Did the city council think the construction project was up to code? $\mathrm{N}$

48. The committee praised the cripple/astronaut who was hurt on the voyage to Mars. They said that his/the disability only made the achievement more remarkable.

Did the committee praise the astronaut/cripple? Y

49. No one talked to the barista/skydiver for very long. They couldn't stand his/the coffee breath, and so avoided talking to him.

Did the barista/skydiver have bad breath? Y

50. Several friends congratulated the bartender/counselor at the dinner party. They asked for his/the martini recipe afterwards because they were so impressed. 
Were the friends unimpressed by the martini recipe? $\mathrm{N}$

51. Few passersby still help the beggar/watchman who sleeps in the street. They are put off by his/the pleading and mostly ignore him.

Do most people help the beggar/watchman in the street? $\mathrm{N}$

52. The girls didn't like the bully/stud who was on lifeguard duty. They began ignoring his/the threats to kick them out of the pool and eventually he left them alone.

Did the girls ignore the threats? Y

53. Some bears attacked the camper/twit in the woods. They tore through his/the tent to get at the canned food he had brought.

Did the bears ignore the tent and food? $\mathrm{N}$

54. The nurses pitied the lunatic/candidate in the hospital. They knew that his/the insanity was the result of a degenerative brain disease.

Was the insanity the result of a brain disease? Y

55. The executives called the slacker/workman in for a conference. They warned that his/the procrastination would no longer be tolerated.

56. The doctors tended to the conductor/philosopher in the hospital. They were told that his/the train had derailed, nearly crushing him to death.

Were the doctors told that the train stayed on the tracks? $\mathrm{N}$

57. The townspeople cheered the cowboy/reverend who won the race. They said his/the horseback riding was absolutely superb.

Did the cowboy/reverend win the race? Y

58. Many neighbors doubted the psychic/farmer during the drought. They feared that his/the prediction for a good rainfall would turn out to be total rubbish.

Did the neighbors believe the psychic/farmer during the drought? $\mathrm{N}$

59. The judges criticized the florist/performer in the competition. They said his/the bouquets, given to him by friendly admirers, were hardly well deserved.

Did the judges think the bouquets were well deserved? $\mathrm{N}$

60. The audience booed the impostor/beginner who was doing impressions. They didn't care for his/the fakery and tried to throw him off the stage.

Did the audience try to throw the impostor/beginner off the stage? Y 
61. The bachelorettes competed over the hunk/heir at the party. They couldn't resist his/the handsome face and flirted with him all night.

Did the bachelorettes ignore the hunk/heir? $\mathrm{N}$

62. The fans booed the quarterback/substitute during the game. They thought that his/the fumble was likely to cost them the match.

63. The villagers ignored the warlock/analyst before the storm. They didn't trust his/the arcane knowledge even when he was trying to help them.

Did the villagers distrust the warning? Y

64. The teachers punished the surfer/wretch for bad behavior. They indicated that his/the flipflops were in violation of school dress code.

Were the flipflops in accordance with the dress code? $\mathrm{N}$

\section{Phonological conditions}

1. Several publishers approached the journalist/congressman who had recently made headlines. They said that his/the journey into fame had only just begun.

2. The maids lectured the carpenter/journalist for being terribly messy. They stared at his/the carpet, which was covered with mud stains.

3. The military prosecutors questioned the civilian/therapist during the trial. They focused on his/the theft of confidential patient files.

4. Many people pitied the photographer/therapist who was afraid of spiders. They knew that his/the phobia could be crippling.

Was the photographer/therapist afraid of spiders? $\mathrm{N}$

5. Some housewives visited the minister/hunter, who was gardening in the front yard. They commented that his/the mint was coming in rather nicely.

Was the minister/hunter in the kitchen? $\mathrm{N}$

6. The accountants met with the reverend/minister for several hours. They thoroughly examined his/the revenue from all of the investments he made last year.

Did the accountants meet with the reverend/minister? Y

7. The guests thanked the manager/player at the exclusive cocktail party. They walked around his/the mansion and praised the décor.

Did the guests dislike the food? N 
8. The receptionists flirted with the attorney/manager in the office. They delighted in his/the attention, and so their flirting began to get a little excessive.

Did the receptionists' flirting get a little excessive? Y

9. The CIA agents scrutinized the chairman/terrorist for the suspicious transactions. They feared that his/the charity was merely a front for a more nefarious plot.

Did the CIA think that the charity was real? $\mathrm{N}$

10. The TV producers insulted the reporter/champion who had become famous during the Olympics. They knew that his/the reply would be quick and insulting.

Did the TV producers think the reply would be kind? $\mathrm{N}$

11. The actresses criticized the chauffeur/bodyguard for having a bad attitude. They couldn't stand his/the chauvinism because it had started to spread to the other men.

12. The agents were after the sheriff/killer for the recent murder. They said that his/the shed was full of incriminating evidence.

Did the agents arrest the sheriff/killer? Y

13. The hostage negotiators freed the captain/doctor with clever trickery. They reasoned with his/the captors until he finally was released.

14. Some robbers attacked a knight/priest who was traveling to Avignon. They struck his/the knife out of the palm of his hand and demanded all his money.

15. The girls thanked the officer/agent politely for the invitation. However, they were skeptical of his/the offer to dine at his home that evening.

Were the girls rude to the officer/agent? $\mathrm{N}$

16. The plaintiffs argued with the judge/lawyer after the trial. They thought that his/the justification of the defendant's actions was completely inappropriate.

Did the plaintiffs think the verdict was arrived at fairly? $\mathrm{N}$

17. Many critics admired the producer/graduate from the acclaimed art school. They referred to his/the program as the best one in town.

18. The rebels deposed the general/president who had recently risen to power. They wouldn't tolerate his/the genocide of so many minority populations.

Were many majority populations killed in the genocide? $\mathrm{N}$

19. The doormen let the student/gentleman into the apartment complex. They talked about his/the studio in the basement of the building. 
20. The donors watched the gentleman/student at the charity drive. They suspected that his/the generosity was all for show.

Were the donors suspicious of the generosity? Y

21. The doctors told the painter/teenager to prepare for the worst after the operation. They hoped his/the painkillers would help ease his suffering.

22. The students glared at the intern/advisor who accidentally sat in on the meeting. They found his/the interruption really rude and annoying.

Did the intern/advisor sit in on the meeting? Y

23. The neighbors knew the gardener/playboy was a little eccentric. When they found his/the garbage in the middle of the street, however, they felt he had gone too far.

24. The reporters interviewed a(n) member/artist of(from) the local performing arts center. They asked about his/the memoir which had been recently published.

25. The managers scolded the bellboy/rocker for eating too much. They pointed at his/the belly bulging out of his skinny jeans.

26. The servant girls congratulated the prince/cook on the amateur artwork. They thought that his/the printings were so beautiful they should be put up in all the rooms of the castle.

Were renovations recently made to the palace? Y

27. The con men watched the grandpa/senator react to the news about the fake sweepstakes. They smiled at his/the gratitude, knowing there was really no check in the mail.

Was there really a check in the mail? $\mathrm{N}$

28. Most people ignored the warden/psycho who was known to make dire predictions. They laughed about his/the warning about the massive prisoner escape plot being hatched.

Did most people pay attention to the warden/psycho? $\mathrm{N}$

29. Many friends helped the wrestler/realtor at the scene of the car accident. They gazed at his/the wreck down in the ditch and shook their heads in sympathy.

Was the wreck down in a ditch? Y

30. The women avoided the deputy/singer who was accused of being a sex offender. They whispered about his/the depravity and refused to speak to him.

Did the women whisper about the deputy/singer? Y 
31. The maintenance men told the singer/deputy there would be a delay. They said that his/the sink wouldn't be installed until next month.

Did the maintenance men say there was no delay? $\mathrm{N}$

32. Some wolves had been troubling a shepherd/resident in the local village. They had raided his/the shelter in the woods and eaten all his food.

Did the wolves leave the food alone? $\mathrm{N}$

33. The environmentalists criticized the policeman/engineer who was caught dumping toxic waste. They claimed that his/the pollution set a poor example for citizens.

Did the environmentalists think the policeman/engineer set a good example? $\mathrm{N}$

34. The ladies calmed down the waiter/baron who had just knocked over a tray full of drinks. They said that his/the wailing was disrupting the guests.

Was the waiter/baron wailing? Y

35. The prosecutors frowned at the admiral/surgeon after the confession. They suspected that his/the admission was really just a way of covering someone else's tracks.

Did the prosecutors think the admiral/surgeon was covering someone else's tracks? Y

36. The trainers evaluated the swimmer/recruit after a hard day's work. They said that his/the swiftness of movement was the key to success.

Did the trainers say the swiftness of movement was bad? $\mathrm{N}$

37. The secretaries complained about the commander/director who sent unintelligible memos. They couldn't understand his/the comments even when they were very short.

38. The players brought the coach/driver back the missing belongings. They had found his/the coat on one of the bus seats along with a pair of sunglasses.

39. The royal family praised the emperor/citizen for the well-delivered speech. They commended his/the emphasis on every word and his clear intonation.

Did the emperor/citizen make a speech? Y

40. The clerks saw the executive/salesman hurry into the meeting late. They snickered at his/the exertion after running all the way to the office.

41. The police questioned the professor/boyfriend of the recently murdered girl. They were shocked by his/the profanity when they finally convinced his to talk. 
42. The reporters kicked the criminal/genius out of the office after the interview. They couldn't tolerate his/the criticism of women and blatant sexism.

43. The colleagues asked the boxer/critic to tidy up the shared workspace. They complained that his/the boxes were cluttering the space.

Were the boxes all cleaned up and organized? $\mathrm{N}$

44. The party guests avoided the acrobat/sheikh from the foreign country. They could smell his/the acrid odor from across the room.

Did the party guests like the smell at the party? $\mathrm{N}$

45. The family visited the actor/pilot after the heart attack. They insisted that his/the actuary draw up a new life insurance policy.

Did the family visit the actor/pilot? Y

46. The diplomats asked the ambassador/emperor to speak more plainly. They said that his/the ambiguous demands needed to be clarified.

Did the diplomats want less ambiguous demands? Y

47. The neighbors reported the architect/amateur for threatening public safety. They claimed that his/the archery practice was not safe and should be moved elsewhere.

Did the neighbors think the archery practice was safe? $\mathrm{N}$

48. The committee praised the astronaut/cripple who took the voyage to Mars. They said that his/the astonishing goals were an inspiration to all.

49. No one talked to the barista/skydiver for very long. They were annoyed by his/the barrage of constant questions.

Did the barista/skydiver ask lots of questions? Y

50. Several friends visited the bartender/counselor last weekend. They really enjoyed his/the barbecue and were impressed with his cooking skills.

Did the friends dislike the barbecue? $\mathrm{N}$

51. Few passersby help the beggar/watchman who sleeps in the street. They are put off by his/the begrudging thanks for their efforts to help.

52. The girls didn't like the bully/stud who was on lifeguard duty. They took away his/the bullhorn so that he couldn't yell at them any more.

Did the girls take away the bullhorn? Y

53. Some bears attacked the camper/twit in the woods. They left behind his/the camcorder, which documented his grisly death. 
Did the bears take the camcorder with them? $\mathrm{N}$

54. The nurses pitied the candidate/lunatic in the hospital. They knew that his/the cancer was eating away at his brain.

\section{Was the cancer eating away at the brain? Y}

55. The executives scolded the workman/slacker about the company's finances. They fired up his/the worries about imminent downsizing.

Did the executives praise the workman/slacker? $\mathrm{N}$

56. The doctors tended to the conductor/philosopher in the hospital. They promised that his/the contusion would eventually heal.

Did the doctors say the contusion would never heal? N

57. The villagers mocked the cowboy/reverend who was scared of thunder. They laughed at his/the cowardice and couldn't take him seriously.

Was the cowboy/reverend scared of thunder? Y

58. Several customers sued the farmer/psychic for selling bogus merchandise. They claimed his/the farce had gone on quite long enough.

Did the customers think the merchandise was legitimate? $\mathrm{N}$

59. The judges criticized the florist/performer in the competition. They said his/the florid shirt simply distracted from his display.

Did the judges think the shirt was good with the display? $\mathrm{N}$

60. The audience booed the impostor/beginner who was doing impressions. They disliked his/the impudence and tried to throw him off the stage.

61. Most investors liked the hunk/heir with expertise in stocks. They relied on his/the hunches to decide where to invest.

Did the investors dislike the hunk/heir? N

62. The fans booed the quarterback/substitute during the game. They thought his/the quarrel with the ref was going to get him kicked off the field.

Did the fans boo the quarterback/substitute? Y

63. The villagers ignored the warlock/analyst before the storm. They believed that his/the warning about the impending flood was bogus.

Did the villagers ignore the warlock/analyst? Y

64. The teachers punished the surfer/wretch for bad behavior. They wouldn't tolerate his/the surly attitude in the classroom any longer. 
Did the teachers reward the surfer's/wretch's attitude? $\mathrm{N}$

\section{Fillers}

1. The librarian said that Alicia needed to shelve all of the books by the end of the afternoon. She had time to shelve only some of them before going home for the day.

Was it the librarian who was supposed to shelve books? N

2. The students were supposed to do all of the reading before answering the questions. It was obvious that Ann did only some of it since her responses made no sense.

Did the students have any assigned reading? Y

3. The contractor promised to complete all of the renovations by the end of the summer. By the end of July he had finished only some of them due to a lot of bad weather.

Was it a budget problem that delayed the renovations? $\mathrm{N}$

4. The kindergarten teacher hoped that the children in the class would be obedient. She was dismayed to find that only some of them listened to her instructions.

Was the teacher expecting well-behaved children? Y

5. The curator hoped that all of the paintings would sell for thousands of dollars. He was disappointed to learn that only some of them were considered valuable.

Did the curator expect the paintings to be valuable? Y

6. The chef wanted all of the customers at the restaurant to be wowed by the food. He knew from experience that only some of them would appreciate its subtlety.

Did the chef care about the customers' opinions? Y

7. During the trip to the zoo, Susie was determined to feed most of the animals food from her lunch. The zookeeper reminded her that only some of them were safe to feed by hand.

Did Susie want to feed the animals at the zoo? Y

8. The dentist hoped that the patients would feel comfortable during their cleanings. He was resigned to the fact that only some of them would actually enjoy their visits.

Did the dentist expect everyone to enjoy having their teeth cleaned? $\mathrm{N}$ 
9. The mayor hoped that all of the members of his cabinet were honorable and trustworthy. Nevertheless he conferred with only some of them about the most sensitive issues.

Did the mayor always consult with the entire cabinet? $\mathrm{N}$

10. The ballerina promised to learn most of the choreography for the difficult new routine by heart. Her dancing partner had mastered only some of it in time for the first rehearsal.

Was it the ballerina who wasn't prepared for the rehearsal? $\mathrm{N}$

11. The babysitter hated missing a lot of good TV shows when the kids stayed up too late. She was happy that tonight she missed only some of them since they were well behaved.

Was it the kids who didn't want to miss the TV show? $\mathrm{N}$

12. Courtney needed to get the homework done before going out with her friends. By 9:00 she had managed to finish only some of it but went out for a beer anyway. Did Courtney stay home all night to finish her work? $\mathrm{N}$

13. The hairdresser wanted all of the customers to leave the salon feeling beautiful. She was distressed to hear that only some of them appreciated her edgy haircuts. Did the hairdresser try to please her customers? Y

14. The yoga instructor expected that all of the students would bring their own mats. This morning she was annoyed that only some of them had come to class prepared.

Were the students supposed to bring their own mats to class? Y

15. The novelist hoped that a lot of bookstores would display his new book prominently. His agent informed him that only some of them would market the book aggressively.

Did the novelist have a new book coming out? Y

16. The congressman promised that the constituents would notice improvements this year. It was depressing to know that only some of them would give him any credit.

Was it the congressman who promised improvements? Y

17. The nutritionist wanted all of the food at McDonald's to be labeled with a health warning. The fast food spokesman insisted that only some of it was high in fat and cholesterol. 
Did the nutritionist think that McDonald's food poses health risks? Y

18. The professor hoped that the class would be able to solve most of the problems on the exam quickly. The students complained that only some of them could be done without a calculator.

Did the professor want the problems on the exam to take a long time? $\mathrm{N}$

19. The fans hoped that the basketball team would win a lot of home games this season. In the end they managed to win only some of them due to a series of injuries.

Was it bad coaching that prevented the team from being successful? $\mathrm{N}$

20. Julia assured her friends that the psychics she'd visited were definitely phonies. Vanessa reminded her that only some of them had actually given her bad advice. Did Julia generally trust psychics? N

21. The football team was supposed to finish all of the drills before the end of practice. The quarterback thought that only some of them were really necessary for the team.

Did the football team have drills to do in practice? Y

22. The new cheerleaders needed to know the cheers for tonight's football game. Melissa had time to practice only some of them before heading out to the field. Was it a basketball game that the cheerleaders were preparing for? $\mathrm{N}$

23. The promoter said the band should play a lot of new songs during their European tour. Their agent advised them to play only some of them since the fans liked the old album.

Was the band's tour in Europe? Y

24. Abigail hoped that the girls on her new softball team would be great athletes. In the first practice she saw that only some of them knew how to throw the ball.

Was Abigail hoping the softball team would be friendly? $\mathrm{N}$

25. Ryan was seriously injured in a car accident. He had been recovering in the hospital for a week. The nurse said that he would have to remain in bed until the broken ribs healed.

Was Ryan in the hospital to have a tumor removed? $\mathrm{N}$

26. John is known to be a very heavy drinker. He spent last Friday night at the local pub downing shots. The waitress thought that he should not have drunk so much high-proof liquor. 
Did John spend last Friday night drinking? Y

27. Kyle was planning to cook an elaborate dinner. He went to the grocery store looking for imported cheeses. The cashier said that he would have to try the gourmet market across town.

Was Kyle cooking for a formal luncheon? N

28. James was excited to be flying for the first time. He kept getting up to look around the plane. The flight attendant said that he would have to stay seated because of all the turbulence.

Did James sleep through the whole flight? N

29. Jacob was a marriage counselor. He was currently working with an unhappy couple who fought all the time. The wife hoped that he would be able to listen to both sides of the story equally.

Was Jacob working with a happy couple? N

30. Kevin was hired to take photos for a wedding. He had a lot of experience working with unattractive clients. The bride hoped that he would be able to make the couple look good in the pictures.

Did Kevin have experience taking photographs? Y

31. Brian was making reservations for a vacation at a beach resort. He wanted to stay in the very best room at the hotel. The receptionist said that he would have to pay extra for the penthouse suite.

Did Brian want to stay in a nice room? Y

32. Jason felt guilty about having shoplifted from a candy store. He went to the church to confess the sin. The nun affirmed that he would be forgiven for such a small crime.

Did Jason steal something from a candy store? Y

33. Scott accidentally tore a hole in a very expensive shirt. He brought it to a nearby shop to be mended. The seamstress promised that he would be able to pick up the mended shirt on Friday at the latest.

Did Scott tear a hole in a pair of pants? $\mathrm{N}$

34. Bryan was the manager of a singing group. He managed to negotiate a prestigious gig at the White House. The soprano hoped that he would be able to keep finding exciting opportunities for the group.

Did Bryan land the group a great gig? Y 
35. Ethan lives next door to a house with a large family. He likes to sit on the porch and chat with the older relatives. The grandmother thinks that he should try to spend time with other kids instead.

Does Ethan have some elderly next-door neighbors? Y

36. Jared was making arrangements for a funeral. He had a difficult conversation with the family of the deceased. The widow expected that he would be able to make the body look alive for the visitation.

Was Jared making arrangements for a wedding? $\mathrm{N}$

37. Peter was working as an assistant on a Hollywood movie set. He was often burdened with unreasonable demands. The lead actress declared that he needed to get coffee for the entire staff every morning.

Was Peter working on a movie set? Y

38. Keith was very worked up about the championship game. He started shouting when a foul was called on the home team. The cheerleader said that he would have to calm down to avoid being thrown out of the game.

Was Keith calm about the game? N

39. Dylan had to go to court about a parking ticket. He had parked illegally in front of a fire hydrant. The metermaid maintained that he should have paid for parking at the nearby lot.

Was Dylan in court about a speeding ticket? $\mathrm{N}$

40. Daniel got a job as a housekeeper in a mansion. He often got lost in the winding corridors of the huge house. The nanny said that he would be able to find all the important rooms within a few weeks.

Was Daniel working at a large hotel? N

41. Justin was staying at a shabby hotel. He called the front desk when the toilet started overflowing. The maid promised that he would have a working toilet within two hours.

Did Justin have a problem with the toilet? Y

42. Joseph was in big trouble at school. He had started a fight that turned into a school-wide brawl. The headmistress insisted that he would have to apologize to the innocent bystanders who had been injured.

Was Joseph in trouble for fighting at school? Y 
43. Robert was often disruptive at school. He started a food fight in the cafeteria yesterday and got caught. The lunch lady declared that he would have to clean up the mess alone to learn a lesson.

Did Robert help make a mess in the cafeteria? Y

44. Tyler worked as a speechwriter at the White House. He was called in on Monday for a very important assignment. The first lady said that he needed to write a statement to be given to the press on Friday.

Did Tyler work in Congress? $\mathrm{N}$

45. Steven wanted to try a more exciting hair style. He decided to get a mohawk and dye it purple. The hair stylist promised that he would not regret choosing an edgy new look.

Did Steven want to get a traditional hair cut? $\mathrm{N}$

46. Andrew was getting married in a few hours. He had a panic attack in the limousine on the way to the church. The maid of honor hoped that he would be able to calm down in time for the ceremony.

Was Andrew feeling calm about the wedding? $\mathrm{N}$

47. David joined the high school band this semester. He was having trouble learning to play while marching. The flute player promised that he would be able to manage the trickier moves after a little practice.

Did David play in the school marching band? Y

48. Aaron was a livestock veterinarian in a rural area. He was visiting a remote farm to see a sick cow. The milkmaid hoped that he would be able to diagnose why the cow had stopped making milk.

Was Aaron visiting a sick animal? Y

49. Ethan needed to pass all his exams in the last week of school in order to graduate. Without much effort, he passed some in math and chemistry, but the rest were far too difficult.

Was it in biology that Ethan managed to pass the exams? $\mathrm{N}$

50. Seth wanted to make all the side dishes before the first guests arrived for dinner.

By late afternoon, he made some including mashed potatoes, but the rest were still on the stove.

Did Seth make the mashed potatoes in time? Y 
51. Tara meant to read all the assigned articles before her discussion section on Friday. On Thursday night, she read some before going to sleep, but the others were much too long.

Was Tara planning to blow off her assigned reading? $\mathrm{N}$

52. Hannah decided to cook all her meals at home each week to avoid gaining any weight. During finals week, she cooked some using healthy ingredients, but the rest were just fast food.

Was Hannah trying to avoid gaining weight? Y

53. Dustin said he would help out by decorating all the classrooms for Parent's Night. Today after school, he decorated some with colorful streamers, but the rest were left totally bare.

Was it the auditorium that Dustin decorated? $\mathrm{N}$

54. Gary hoped to win all the prizes for biology at the national science fair this year. As everyone expected, he won some for his novel experiment, but the rest went to another student.

Did Gary win awards for physics? N

55. Nicole was supposed to eat all her vegetables before getting to have any dessert. At dinner last night, she ate some without throwing a fit, but the rest remained on her plate.

Did Nicole have to eat vegetables to get dessert? Y

56. Rachel wanted to visit all the capital cities in Europe before leaving for college. Over the summer, she visited some traveling by bus or train, but the others were beyond her budget.

Was Rachel planning to visit European capitals? Y

57. Max wanted to take all the advanced graduate courses offered by the physics department. In his last semester, he took some and got decent grades, but the others were way over his head.

Did Max want to take the easiest classes available? N

58. The gardener decided to plant all the oak trees along the north side of the house. Yesterday morning, he planted some in that area of the yard, but the others went on the south side.

Was the gardener planting small shrubs? N 
59. The teacher intended to grade all the papers before her favorite TV show came on. Right after dinner, she graded some without much difficulty, but the rest had to wait until later.

Was the teacher planning to grade papers? Y

60. Keith wanted to eat at all the restaurants on his block before the end of the summer. In the first month, he ate at some without gaining any weight, but the rest served very fatty food.

Did Keith want to eat at every restaurant in the city? $\mathrm{N}$

61. Derek wanted to visit all the parks in his hometown to see the foliage changing color. Early this autumn, he visited some when the trees were yellow, but the rest were best in November.

Did Derek want to see the leaves change color? Y

62. The film buff wanted to watch all the Charlie Chaplin movies during the snowstorm. On the first day, he watched some with a group of friends, but the rest weren't available online.

Was it Fred Astaire movies that the film buff wanted to watch? N

63. Jared hoped to meet all the baseball players from his favorite team at spring training. After the first game, he met some and got their autographs, but the others had not yet arrived.

Was Jared hoping to meet some baseball players? Y

64. Emma decided to visit all the Ivy League schools before deciding where to apply early. In her junior year, she visited some during their open houses, but the others were too far to drive to.

Did Emma visit schools during her senior year? $\mathrm{N}$

65. The mailman was supposed to deliver all the packages to the dangerous neighborhood. Despite his fears, he delivered some before it got too dark, but the rest were stolen from the truck.

Was the mailman afraid of the dangerous neighborhood? Y

66. The film critic was supposed to review all the blockbuster movies released this week. In Friday's paper, he reviewed some that he had enjoyed a lot, but the rest were utterly terrible.

Was the critic reviewing obscure foreign films? $\mathrm{N}$ 
67. The band manager wanted to watch all the shows during their tour of the East coast. In the beginning, he watched some in New Jersey and New York, but the rest ended up getting cancelled.

Was the band touring the East coast? Y

68. Brenda was hoping to go to all the stores at the mall on the day after Thanksgiving. Early that morning, she went to some before the lines got long, but the rest were much too crowded.

Was it on the day before Thanks giving that Brenda wanted to shop? $\mathrm{N}$

69. Melanie wanted to read all the books from her older sister's summer reading list. Despite her young age, she read some without any assistance, but the others were above her level.

Did Melanie read books that were advanced for her age? Y

70. Todd needed to convince all his coworkers to buy candy for his son's class fundraiser. During his break, he convinced some by calling in a few favors, but the others didn't have any cash.

Was Todd trying to sell popcorn to his coworkers? N

71. The singer wanted to include all the traditional songs on his new holiday album. In the final version, he included some with his agent's approval, but the rest were original songs.

Did the singer want to use all new songs on the album? $\mathrm{N}$

72. The president was pressured to veto all the new tax laws passed this week in Congress. After much debate, he vetoed some to appease his party, but the rest were totally necessary.

Was it tax laws that the president was under pressure to veto? Y 